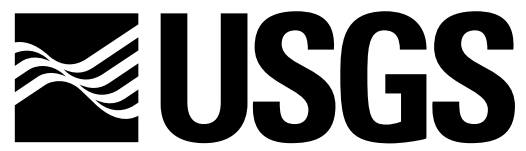

science for a changing world

\title{
Water Use, Ground-Water Recharge and Availability, and Quality of Water in the Greenwich Area, Fairfield County, Connecticut and Westchester County, New York, 2000-2002
}

In cooperation with the town of Greenwich, Connecticut

Water-Resources Investigations Report 03-4300 
U.S. Department of the Interior

U.S. Geological Survey

\section{Water Use, Ground-Water Recharge and Availability, and Quality of Water in the Greenwich Area, Fairfield County, Connecticut and Westchester County, New York, 2000-2002}

By John R. Mullaney

Water-Resources Investigations Report 03-4300

In cooperation with the town of Greenwich, Connecticut 


\section{U.S. DEPARTMENT OF THE INTERIOR \\ GALE A. NORTON, Secretary}

\section{U.S. GEOLOGICAL SURVEY}

Charles G. Groat, Director

The use of firm, trade, and brand names in this report is for identification purposes

only and does not constitute endorsement by the U.S. Geological Survey.

For additional information write to:

District Chief

U.S. Geological Survey

101 Pitkin Street

East Hartford, CT 06108

http://ct.water.usgs.gov
Copies of this report can be purchased from:

U.S. Geological Survey

Branch of Information Services

Box 25286, Federal Center

Denver, CO 80225 


\section{CONTENTS}

Abstract n...1.

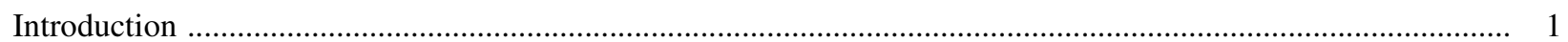

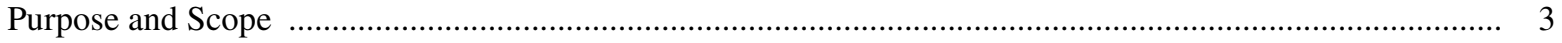



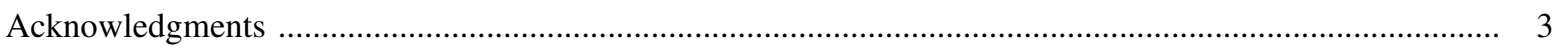

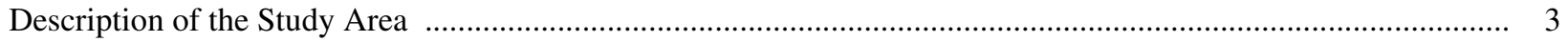



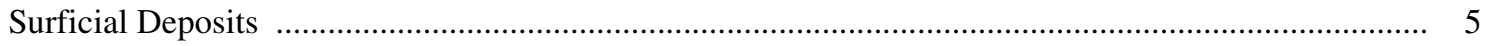

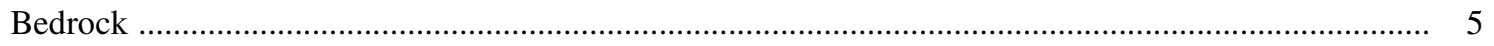

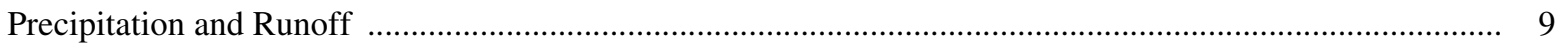

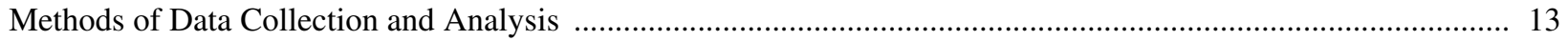

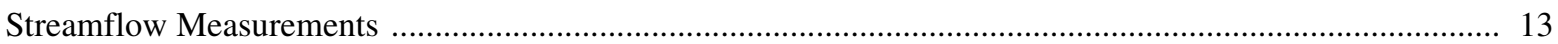

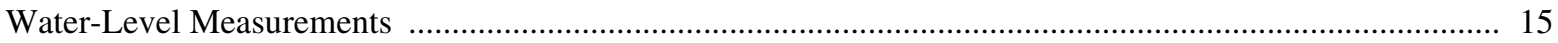

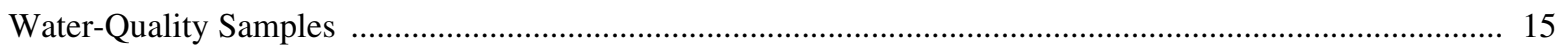

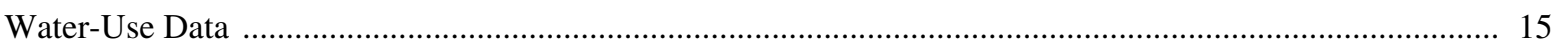

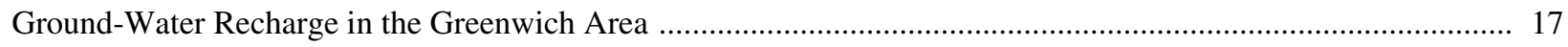

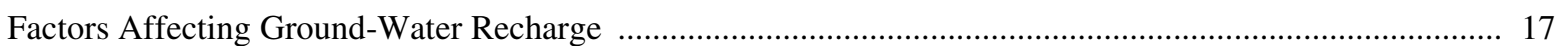

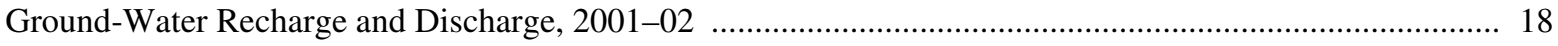



Water Use at Residences with Public Water Supply .......................................................................... 20

Log-Linear Regression Models of Residential Water Use ...................................................................... 21

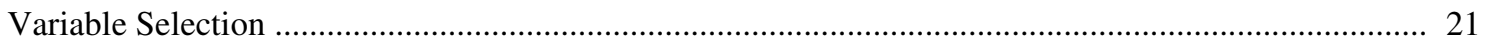

Prediction of Residential Water Use in Areas with Domestic Wells ................................................... 22

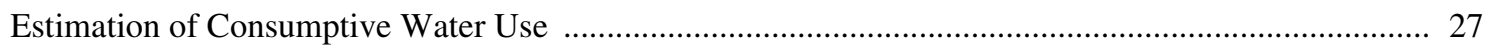

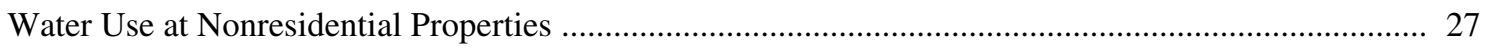

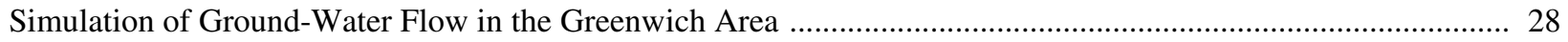

Description of Flow Model and Model Assumptions ........................................................................... 28

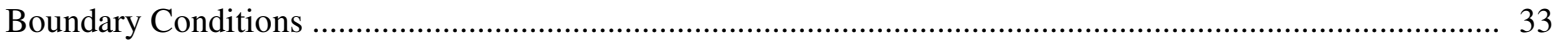



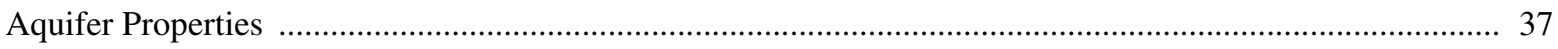

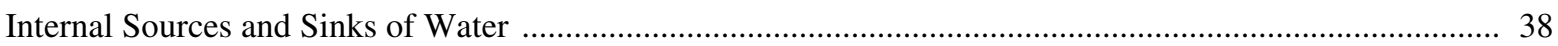

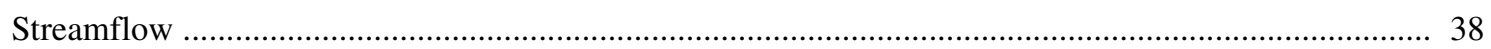

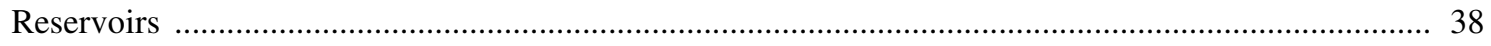

Ground-Water Withdrawals and Return Flow from Septic Systems ................................................. 38

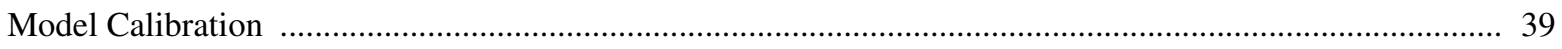

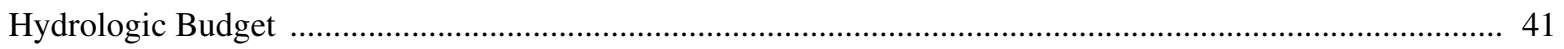

Ground-Water Availability in the Greenwich Area …............................................................................ 47

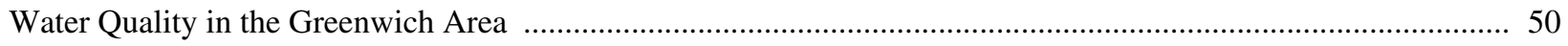

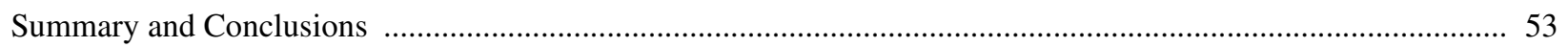

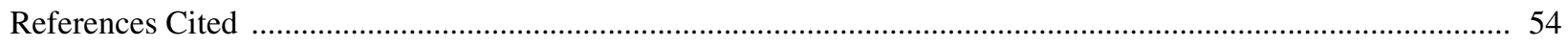

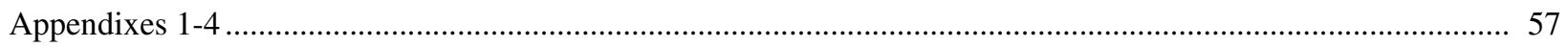




\section{FIGURES}

1. Map showing location of public water and sewer service areas, Greenwich area, Connecticut

2. Map showing location of subregional basins and data-collection sites for streamflow and ground-water-level measurements, Greenwich area, Connecticut

3. Map showing generalized surficial geology of the Greenwich area, Connecticut ..................................... 6

4. Map showing generalized bedrock geology of the Greenwich area, Connecticut .................................... 8

5. Graph showing precipitation at Putnam Lake, Greenwich, Connecticut, 1967-2001 .............................. 10

6. Map showing additional data-collection sites in Fairfield County, Connecticut .................................... 11

7. Graph showing annual mean runoff at two long-term streamflow-gaging stations near Greenwich, Connecticut, 1967-01...

8. Graph showing precipitation at Bridgeport, Connecticut, and runoff at Sasco Brook near Southport, Connecticut (USGS station number 01208950), calendar years 1966-96.

9. Cross section through wells installed for water-level measurements

10. Graph showing water levels in bedrock wells in the East Branch of the Byram River Basin and precipitation at Putnam Lake, Greenwich area, Connecticut, September 2001-October 2002

11. Graph showing quarterly base flow at U.S. Geological Survey streamflow-gaging station number 01211699, East Branch Byram River below Lake Mead at Round Hill, Connecticut.

12. Graph showing frequency distribution for residuals and the "best-fit" normal distribution approximation for (A) average daily water use, (B) average daily summer water use, and (C) average daily winter water use, Greenwich area, Connecticut

13. Graph showing estimates of average daily residential water use per square mile for small basins, Greenwich area, Connecticut

14. Graph showing estimates of average daily return flow per square mile from residential septic systems supplied by public water supply for small basins, Greenwich area, Connecticut

15. Map showing extent of finite-difference ground-water-flow model grid, Greenwich area, Connecticut... 29

16. Cross section through row 14 finite-difference ground-water-flow model, Greenwich area, Connecticut

17. Map showing location of observations for ground-water levels and streamflow, Greenwich area, Connecticut...

18. Graph showing ground-water levels and streamflow, March to May 2002, Greenwich area, Connecticut

19. Map showing zone array based on geology used for (A) application of recharge to the model and (B) application of hydraulic properties to layers 1and 2, steady-state ground-water simulation, Greenwich area, Connecticut.

20. Graph showing instantaneous streamflows per square mile at two continuous streamflow-gaging stations, Greenwich area, Connecticut, March to April 2001

21. Graph showing measured and predicted impervious areas for a random sample of model cells, Greenwich area, Connecticut.

22. Graph showing weighted simulated equivalent plotted against weighted observations of hydraulic head and streamflow for model simulation of the Greenwich area, Connecticut, April 16-24, 2002

23. Map showing simulated long-term, average annual ground-water recharge from precipitation aggregated by zones, Greenwich area, Connecticut.....

24. Map showing simulated long-term average net residential consumptive water use for zones,

Greenwich area, Connecticut.

25. Graph showing simulated ground-water outflow to streams, calculated base flow, and low flow for basins in the Greenwich area, Connecticut.

26. Graph showing percentage of urban land use and concentrations of selected water-quality constituents,

Greenwich area, Connecticut. 


\section{TABLES}

1. Streamflow measurements, Greenwich area, Connecticut, 2000-02 …............................................... 13

2. Wells in the East Branch Byram River Basin, Greenwich, Connecticut ................................................ 15

3. Median daily water use, and median daily seasonal water use by property size, in calendar year 2000 at selected residences with public water supply

4. Parameter estimates, standard errors, t-statistics, and p-values for multiple linear regression model of average daily water use at residences with public water supply, calendar year 2000, Greenwich, area, Connecticut

5. Parameter estimates, standard errors, $t$-statistics and $p$-values for multiple linear regression model of average daily summer water use at residences with public water supply, calendar year 2000, Greenwich area, Connecticut

6. Parameter estimates, standard errors, t-statistics and p-values for multiple linear regression model of average daily winter water use at residences with public water supply, calendar year 2000, Greenwich area, Connecticut

7. Water levels in April 2002 and average water levels at selected U.S. Geological Survey network wells in Fairfield County, Connecticut

8. Recharge estimates from historical values and nonlinear regression for April 2002 calibration

9. Parameter estimates, standard errors, $t$-statistics and $p$-values for multiple linear regression model of percentage of impervious area for randomly selected cells of the finite-difference ground-water-flow model, Greenwich area, Connecticut

10. Simulated values of hydraulic conductivity in finite-difference ground-water-flow model, Greenwich area, Connecticut

11. Parameter estimates of hydraulic conductivity and recharge from nonlinear regression, finitedifference ground-water flow model, Greenwich area Connecticut

12. Summary of error statistics and comparison of observed and simulated ground-water levels, Greenwich area, Connecticut, April 16-20, 2002

13. Observed and simulated streamflows, Greenwich area, Connecticut, April 24-25, 2002.

14. Annual ground-water budget for modeled zones, based on calibration data from April 18-25, 2002, Greenwich area, Connecticut

15. Annual ground-water budget for modeled zones, based on calibration data from April 18-25, 2002 and adjusted to average residential water withdrawals, Greenwich area, Connecticut

16. Estimated net annual residential consumptive water use and the difference between estimated long-term average recharge and the 30-day 2-year low flow......

17. Percentage of urban land use and concentration of selected water-quality constituents in surface-water base-flow samples collected October 2000, Greenwich area, Connecticut

18. Wastewater compounds detected on October 25, 2000 at station number 01211110, Greenwich area, Connecticut

\section{APPENDIXES}

1. Records from two streamflow-gaging stations, March 2001-September 2002 ........................................ 58

2. Estimated average daily ground-water use, Greenwich area, Connecticut ............................................... 62

3. Estimated average daily summer ground-water use, Greenwich area, Connecticut..................................... 63

4. Estimated average daily winter ground-water use, Greenwich area, Connecticut .................................... 64 
CONVERSION FACTORS AND VERTICAL DATUM

\begin{tabular}{|c|c|c|}
\hline Multiply & By & To obtain \\
\hline inch (in.) & 25.4 & millimeter \\
\hline inch per year (in/yr) & 25.4 & millimeter per year \\
\hline foot $(\mathrm{ft})$ & 0.3048 & meter \\
\hline foot per day (ft/d) & 0.3048 & meter per day \\
\hline mile (mi) & 1.609 & kilometer \\
\hline square mile $\left(\mathrm{mi}^{2}\right)$ & 2.590 & square kilometer \\
\hline cubic foot per second $\left(\mathrm{ft}^{3} / \mathrm{s}\right)$ & 0.02832 & cubic meter per second \\
\hline gallon (gal) & 3.785 & liter \\
\hline gallon per day (gal/d) & 0.003785 & cubic meter per day \\
\hline million gallons per day (Mgal/d) & 0.04381 & cubic meter per second \\
\hline \multicolumn{3}{|l|}{ million gallons per day per square mile } \\
\hline$\left[(\mathrm{Mgal} / \mathrm{d}) / \mathrm{mi}^{2}\right]$ & 1,461 & cubic meter per day per square kilometer \\
\hline
\end{tabular}

Temperature in degrees Fahrenheit $\left({ }^{\circ} \mathrm{F}\right)$ may be converted to degrees Celsius $\left({ }^{\circ} \mathrm{C}\right)$ as follows:

$$
{ }^{\circ} \mathrm{C}=\left({ }^{\circ} \mathrm{F}-32\right) / 1.8
$$

Vertical coordinate information is referenced to the North American Vertical Datum of 1988 (NAVD 88).

Horizontal coordinate information is referenced to the North American Datum of 1927 (NAD 27).

Altitude, as used in this report, refers to distance above or below sea level.

Concentrations of chemical constituents in water are given in milligrams per liter $(\mathrm{mg} / \mathrm{L})$ and micrograms per liter $(\mu \mathrm{g} / \mathrm{L})$.

Concentrations of indicator bacteria are given in colonies per 100 milliliters $(\mathrm{mL})$ of sample. 


\title{
Water Use, Ground-Water Recharge and Availability, and Quality of Water in the Greenwich Area, Fairfield County, Connecticut and Westchester County, New York, 2000-2002
}

\author{
by John R. Mullaney
}

\section{ABSTRACT}

Ground-water budgets were developed for 32 small basin-based zones in the Greenwich area of southwestern Connecticut, where crystalline-bedrock aquifers supply private wells, to determine the status of residential ground-water consumption relative to rates of ground-water recharge and discharge. Estimated residential ground-water withdrawals for small basins (averaging 1.7 square miles $\left(\mathrm{mi}^{2}\right)$ ) ranged from 0 to 0.16 million gallons per day per square mile $\left(\mathrm{Mgal} / \mathrm{d} / \mathrm{mi}^{2}\right)$. To develop these budgets, residential ground-water withdrawals were estimated using multiple-linear regression models that relate water use from public water supply to data on residential property characteristics. Average daily water use of households with public water supply ranged from 219 to 1,082 gallons per day (gal/d).

A steady-state finite-difference ground-waterflow model was developed to track water budgets, and to estimate optimal values for hydraulic conductivity of the bedrock ( 0.05 feet per day) and recharge to the overlying till deposits (6.9 inches) using nonlinear regression. Estimated recharge rates to the small basins ranged from 3.6 to 7.5 inches per year (in/yr) and relate to the percentage of the basin underlain by coarsegrained glacial stratified deposits. Recharge was not applied to impervious areas to account for the effects of urbanization. Net residential ground-water consumption was estimated as ground-water withdrawals increased during the growing season, and ranged from 0 to $0.9 \mathrm{in} / \mathrm{yr}$.

Long-term average stream base flows simulated by the ground-water-flow model were compared to calculated values of average base flow and low flow to determine if base flow was substantially reduced in any of the basins studied. Three of the 32 basins studied had simulated base flows less than $3 \mathrm{in} / \mathrm{yr}$, as a result of either ground-water withdrawals or reduced recharge due to urbanization. A water-availability criteria of the difference between the 30-day 2-year low flow and the recharge rate for each basin was explored as a method to rate the status of water consumption in each basin. Water consumption ranged from 0 to 14.3 percent of available water based on this criteria for the 32 basins studied.

Base-flow water quality was related to the amount of urbanized area in each basin sampled. Concentrations of total nitrogen and phosphorus, chloride, indicator bacteria, and the number of pesticide detections increased with basin urbanization, which ranged from 18 to 63 percent of basin area.

\section{INTRODUCTION}

New residential development in Connecticut is taking place in rural upland areas that are outside public water-supply areas. Residents in these areas rely on individual private wells drilled in the fractured crystalline-bedrock aquifer for their water supply. Very little information is available about recharge rates to this aquifer or about the water withdrawals and consumptive use from private domestic wells.

The majority of residents in Greenwich, a community in southwestern Connecticut (fig. 1), rely on public water supply from local and regional surfacewater reservoirs. Aquifers in the glacial stratified deposits in this part of Connecticut are limited in extent; therefore, any future development must rely on ground water from the crystalline-bedrock aquifer for water supply. Ground water is the primary source of water supply for approximately 12 percent of the town's households that are outside the public watersupply area (fig. 1) (U.S. Department of Commerce, 1991). Ground-water recharge is the ultimate source of 


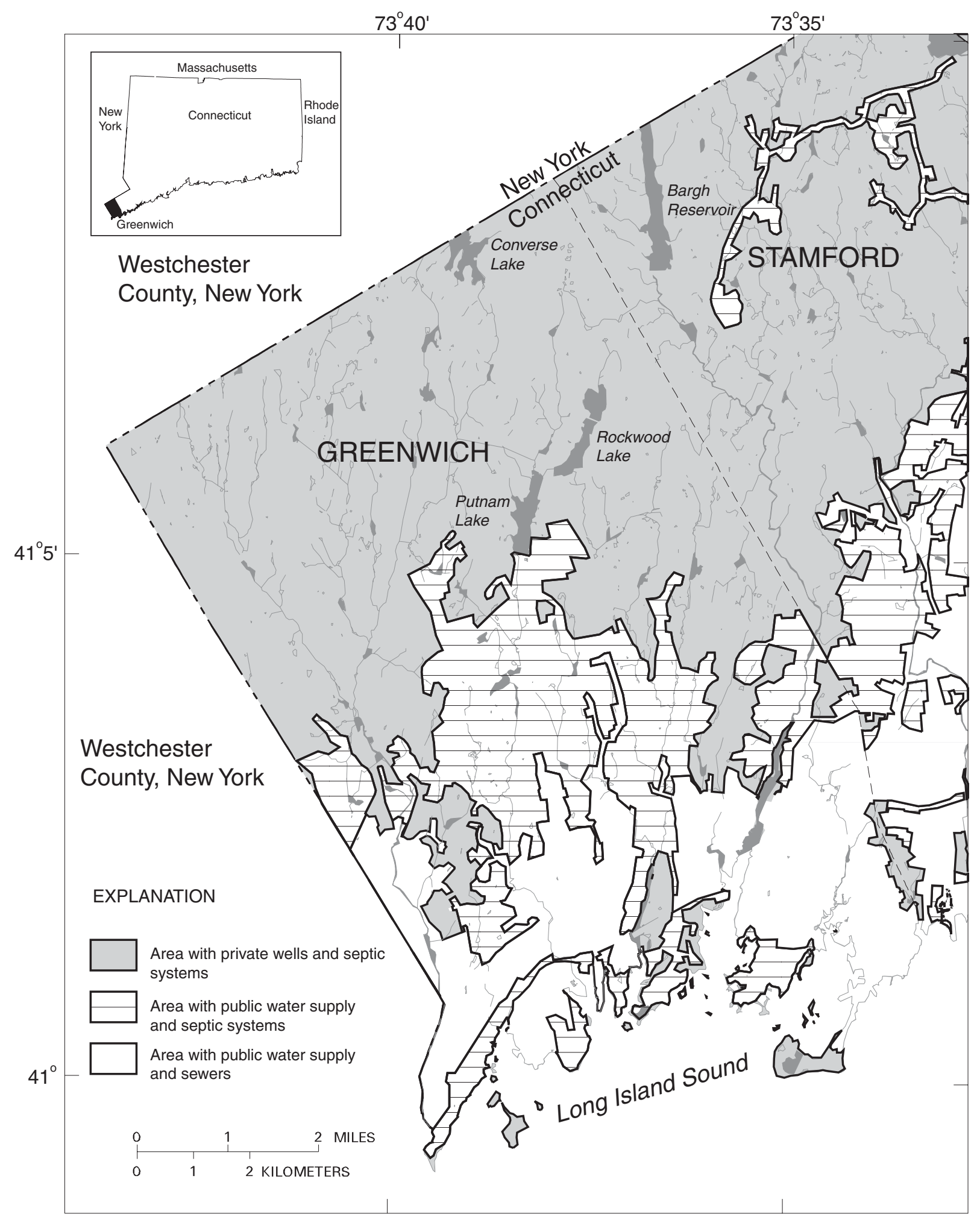

Base from Connecticut Department of Environmental Protection 1994 Digital Line Graph

Projection State Plane Feet Zone 3526

Figure 1. Location of public water and sewer service areas, Greenwich area, Connecticut. 
water to the crystalline-bedrock aquifers, but information is sparse on recharge rates to these bedrock aquifers in New England.

Increasing development and the lack of large glacial stratified aquifers for public water supply have led to a need to study ground-water availability and water use in basins in the Greenwich area. The U.S. Geological Survey (USGS) and the town of Greenwich began a cooperative study in 2000 on water use, ground-water recharge and availability, and quality of water in several coastal basins in southwestern Connecticut. The information presented in this report may be applicable to other parts of New England and New York where the issue of sustainable water use from bedrock aquifers is of increasing concern. Wateruse estimates are relevant especially to other parts of Fairfield County, Connecticut, and Westchester County, New York.

\section{Purpose and Scope}

The purpose of this report is to characterize residential ground-water use, ground-water recharge and availability, and quality of water in selected coastal basins in Fairfield County, Connecticut and Westchester County, New York. The report focuses primarily on the Greenwich, Connecticut area. It presents data collected during 2000 through 2002 on streamflow, ground-water levels, and water quality of base flow. Three multiple-linear regression models were used to estimate self-supplied water use from ground-water sources for average daily, winter, and summer conditions in each of 32 small basin-based zones. A steady-state ground-water-flow model was used as a tool to assist in estimating recharge rates, hydraulic conductivity of crystalline bedrock, and in the analysis of ground-water budgets and ground-water availability for each of the 32 zones.

\section{Previous Investigations}

The ground-water resources of the study area were described previously in several reports. Gregory and Ellis (1916) described the hydrogeology, water supply, and water use in the Greenwich-Stamford area. Ryder and others (1970) conducted a water-resources inventory of the southwestern Connecticut coastal basins, including information on the hydrogeology, surface water, water quality, and water use of the region. Wolcott and Snow (1995) estimated ground- water recharge for northern Westchester County, including some areas in the Byram and Mianus River Basins that drain through Greenwich.

\section{Acknowledgments}

The following town of Greenwich officials and departments are thanked for their assistance with this investigation: Aleksandra Moch, Denise Savageau, and Steven Danzer of the Greenwich Conservation Department; the Greenwich Health Department; and the Greenwich Department of Public Works. The National Audubon Society and the Boy Scouts of America are thanked for allowing ground-water level and streamflow monitoring on their properties; the numerous residents of Greenwich are thanked who allowed access to their wells for water-level monitoring; and David Medd of the Aquarion Water Company of Connecticut is thanked for providing water-use and precipitation information. Thanks also are due to Anna Maria Marrone, assessor of the town of North Castle, New York, and Cindy Barber, GIS analyst for the city of Stamford, Connecticut. The following USGS employees are thanked for their contributions to this study: Gregory Schwarz, Bruce Davies $3^{\text {rd }}$, J. Jeffrey Starn, Remo Mondazzi, Staunton Williams Jr., Timothy Frick, Joseph Martin, and Barbara Korzendorfer.

\section{DESCRIPTION OF THE STUDY AREA}

The study area (fig. 2), referred to in this report as the Greenwich area, contains $52.8 \mathrm{mi}^{2}$ in Fairfield County in the southwestern coastal part of Connecticut and Westchester County, New York. The town of Greenwich, which makes up most of the study area, had a population of 61,101 in 2000 (data accessed on August 26, 2003, on the World Wide Web at URL http://www.census.gov). Development in the Greenwich area ranges from homes on small lots (less than 0.5 acres) and commercial and business districts with public water supply and sewer in the southern part of the town, to large lots (more than 4 acres) and no commercial activity in the more rural northern areas. Residential water use in some parts of the town likely is higher than in other parts of Connecticut due to the large lot size and lawn area and the large number of swimming pools. In 1999, median annual household 


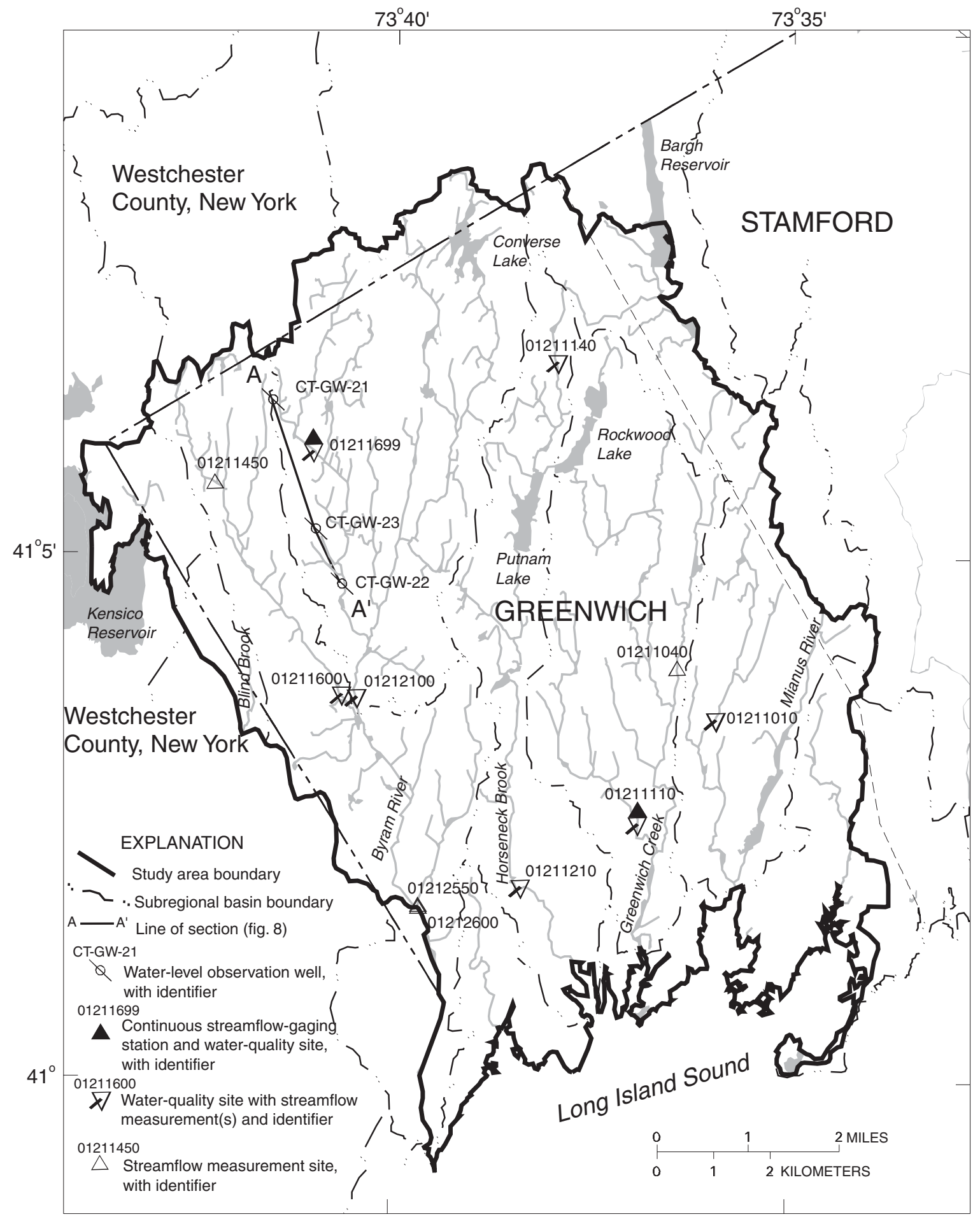

Base from Connecticut Department of Environmental Protection 1994 Digital Line Graph

Projection State Plane Feet Zone 3526

Figure 2, Location of subregional basins and data-collection sites for streamflow and ground-water-level measurements, Greenwich area, Connecticut. 
income in Greenwich was $\$ 99,086$ as compared to the median annual household income of $\$ 53,935$ in the State of Connecticut (data accessed on August 26, 2003, on the World Wide Web at URL http://www.census.gov).

The town of Greenwich is in the Byram River and Mianus River drainage basins. Several smaller subregional basins that also drain to Long Island Sound are within the town (fig. 2). Altitude of the Greenwich area ranges from sea level on Long Island Sound to almost $600 \mathrm{ft}$ near the northern border with Westchester County, New York. The water table is generally shallow and at a consistent depth below land surface at most places in the study area. Water levels in upland areas, such as Greenwich, typically are a subdued reflection of the topography.

\section{Geohydrology}

Two types of aquifers are present in the Greenwich area: (1) aquifers in surficial deposits including till, glacial stratified deposits, post-glacial alluvium, and swamp deposits; and (2) aquifers in the fractured crystalline bedrock.

\section{Surficial Deposits}

The surficial geology of Connecticut has been most recently described by Stone and others (1992). The major surficial deposits in the Greenwich area are till and glacial stratified deposits. Till is an ice-laid deposit containing a nonsorted mixture of gravel, sand, silt, and clay. Till overlies the bedrock in most places in the Greenwich area and is the primary unconsolidated material.

Tills of two separate glaciations are present in Connecticut. The characteristics of these two tills are summarized in Melvin and others (1992). The upper till (surface till) was deposited during the last glaciation from about 23,000 to 16,000 years before present. Surface till is generally sandy with many boulders and is thin in areas with numerous bedrock outcrops. Surface till has been noted up to $33 \mathrm{ft}$ thick in Connecticut (Melvin and others, 1992). The average thickness of the upper till is $12 \mathrm{ft}$ based on well-completion reports for 462 selected wells in Greenwich. The composition of the till is related to nearby bedrock types and to other surficial deposits that were present before the last glaciation. Drumlin till (lower till) is interpreted to have been deposited during an earlier glaciation (Melvin and others, 1992). Drumlin till is inferred to be present in the cores of drumlins and in thick till deposits (drumlin till possibly covered by surface till) in the Greenwich area (fig. 3), and may range in thickness from 30 to $100 \mathrm{ft}$. Based on the selected records of 121 wells in Greenwich, the average thickness of till deposits in areas with thick till is $35 \mathrm{ft}$. Thick till deposits containing drumlin till are present primarily in the northern half of Greenwich (fig. 3).

Glacial stratified deposits include sand and gravel, silt, and clay deposited in glacial meltwater streams or lakes by the retreating glacier (fig. 3). In other parts of Connecticut, these deposits are the most productive aquifers for public ground-water supplies. They are important areas for storing ground water and providing base flow to streams because ground-water recharge rates to these deposits are greater than recharge rates to deposits of till. Glacial stratified deposits are limited in the Greenwich area, as compared to other parts of Connecticut, and consist mostly of small and thinly saturated areas of sand and gravel. The largest area of glacial stratified deposits underlies the Tamarack swamp (fig. 3), in the northwestern part of Greenwich, where swamp deposits overlie fine-grained material and sand. According to Ryder and others (1970), this deposit may contain as much as $120 \mathrm{ft}$ of saturated thickness with a transmissivity of up to $6,700 \mathrm{ft}^{2} / \mathrm{d}$. Several wells completed in another stratified deposit in the Banksville section (fig. 3) of Greenwich (northeastern part of town) were reported to penetrate up to $53 \mathrm{ft}$ of fine-grained sand. Some residents in Banksville obtain their water from shallow dug wells completed in this material (Aleksandra Moch, Greenwich Conservation Department, oral commun., 2001).

\section{Bedrock}

The Greenwich area is underlain by metamorphic bedrock of two different geologic terranes (Rodgers, 1985). The northwestern part of Greenwich is underlain by Proto-North American terrane, which is thought to be the edge of the Proto-North American continent. The remainder of Greenwich is in the Iapetos terrane of the western uplands of Connecticut, which is thought to be oceanic sediments that were offshore from Proto-North America. Bedrock to the northwest of Cameron's line (a fault, see fig. 4) includes granitic gneiss, gneiss, schistose marble, schist, and amphibolite (fig. 4). The oldest bedrock 


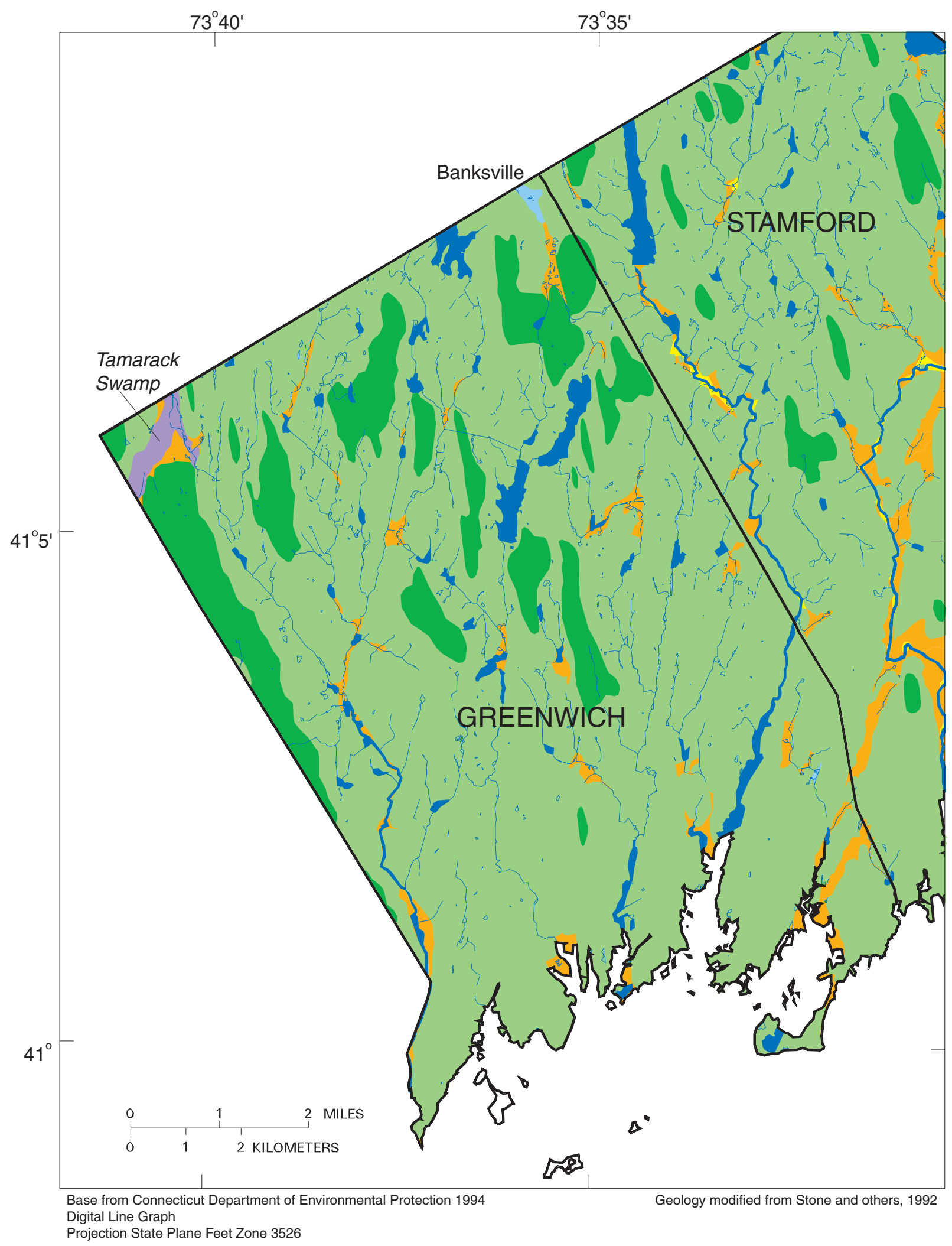

Figure 3, Generalized surficial geology of the Greenwich area, Connecticut. 


\title{
EXPLANATION
}

\author{
WATER BODIES
}

POSTGLACIAL DEPOSITS

ALLUVIUM OVERLYING SAND AND GRAVEL--Sand, gravel, silt, and some organic material on the flood plains of modern streams; overlie "sand and gravel" described below

SWAMP--Muck and peat that contain minor amounts of sand and silt accumulated in poorly drained areas. Generally less than 10 feet thick

\section{GLACIAL MELTWATER DEPOSITS}

All sorted and stratified sediments composed of gravel, sand, silt and clay laid down by flowing meltwater during retreat of the last ice sheet; includes minor lenses of flowtill and other diamict sediments

FINE DEPOSITS--Composed of fine sand, silt, and clay particles generally in well sorted, thin layers of alternating silt and clay and (or) very fine sand; locally may contain lenses of coarser material. Fines, if present, overlie sand and gravel described below

SAND AND GRAVEL--Composed of mixtures of sand and gravel within individual layers and as alternating layers. Sand and gravel layers generally range from 50-75 percent sand particles and from 25-50 percent gravel particles. Unit locally contains zones that are entirely sand

\section{GLACIAL ICE-LAID DEPOSITS}

TILL--Poorly sorted, generally nonstratified mixture of grain sizes ranging from clay to large boulders; the matrix of most tills is composed dominantly of sand and silt. Darker green areas indicate till 15 feet or greater in thickness 


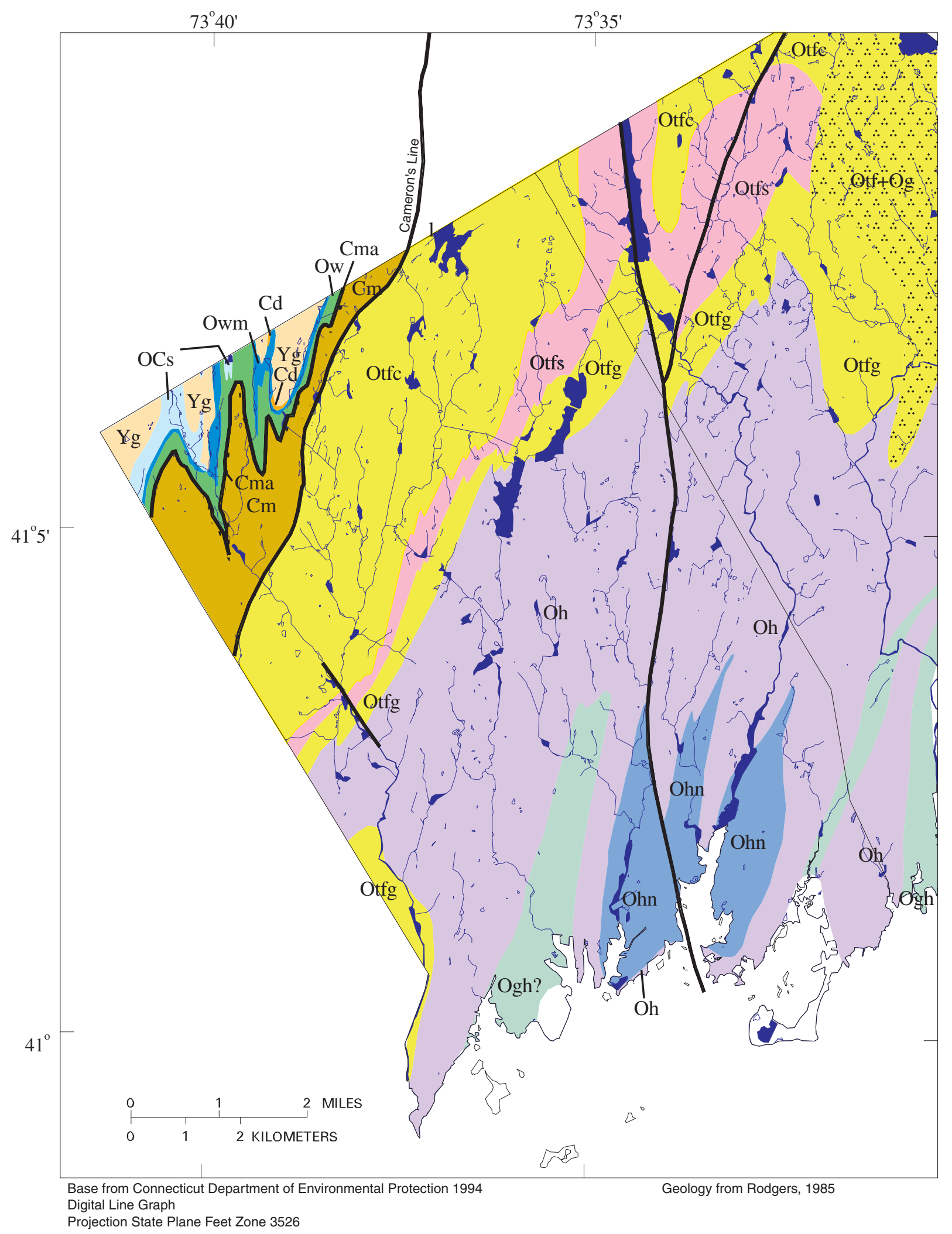

Figure 4. Generalized bedrock geology of the Greenwich area, Connecticut. 


\title{
EXPLANATION
}

\author{
Otfc Carringtons Pond Member of Trap Falls Formation \\ Otfs Shelton (white gneiss) Member of Trap Falls Formation \\ $0 \mathrm{t}+\mathrm{g}$ Trap Falls Formation and granitic gneiss \\ Otfg Schist and granulite member of Trap Falls Formation \\ Ohn Nodular member of Harrison Gneiss \\ Oh Harrison Gneiss \\ Ogh Golden Hill Schist \\ Owm Basal marble member of Walloomsac Schist \\ Ow Walloomsac Schist \\ OCs Stockbridge Marble \\ Cma Amphibolite-bearing unit of Manhattan Schist \\ Cm Manhattan Schist \\ Cd Dalton Formation \\ Yg Gneiss of Highlands masifs \\ $\Upsilon$ Faults
}

units are the gneisses of Highland Massifs and are Proterozoic in age. The shelf-sequence rocks (marble and schistose marble) are Cambrian and Ordovician in age. Bedrock in the area southeast of Cameron's line primarily includes schist, gneiss, and granitic gneiss. These rocks are lower to middle Ordovician in age.

Foliation of bedrock in the Greenwich area typically strikes N-NE and dips west at 34 to 80 degrees (Rodgers, 1985). The stream-drainage network apparently is strongly controlled by the underlying rock structure, and many streams are parallel to the strike of the foliation. Many high-angle fractures in the bedrock likely coincide with the direction of foliation. Another pattern in the stream-drainage network suggests structural features that strike N-NW; this could be another major direction of fractures in the underlying bedrock. Water moving through the crystalline bedrock, primarily through networks of interconnected fractures, supplies most private wells in Greenwich.

\section{Precipitation and Runoff}

The climate of the Greenwich area is humid, and the average annual precipitation during the 30 -year period 1967-96 was $49.9 \mathrm{in} / \mathrm{yr}$ as measured at Putnam Lake (fig. 2) (David Medd, Aquarion Water Company 
of Connecticut, written commun., 2002) (ig. 5 ).

During this period, precipitation ranged from 30.5 in. (in 1995) to 68.9 in. (in 1983). Median annual precipitation in the Greenwich area during 1951-80 ranged from 46 to 50 in. (Hunter and Meade, 1983). Smaller amounts of precipitation occur near the coast; the larger amounts occur at higher elevations in northern Greenwich and are the results of orographic uplift.

Mean annual runoff from streams in the Greenwich area during 1930-60 ranged from about 21 to 23 in. (Ryder and others, 1970). Annual mean runoff from two nearby USGS streamflow-gaging stations (01208950, 01208990, fig. 6) during 1967-01 ranged from 13 to 46 in. (fig. 7). The difference between precipitation and runoff represents water lost through evapotranspiration. The average difference between precipitation at Bridgeport, Connecticut, and annual mean runoff from Sasco Brook near Southport (station 01208950, fig. 6), Connecticut, during 1966-96 was 17.9 in. (fig. 8). This value is probably very similar to the evapotranspiration rate for the Greenwich area. Annual variations in the relation between precipitation and runoff can be attributed primarily to variations in ground-water storage and climatic factors such as temperature, humidity, wind speed, and cloud cover. Natural long-term differences in annual mean runoff are related primarily to long-term local differences in precipitation.

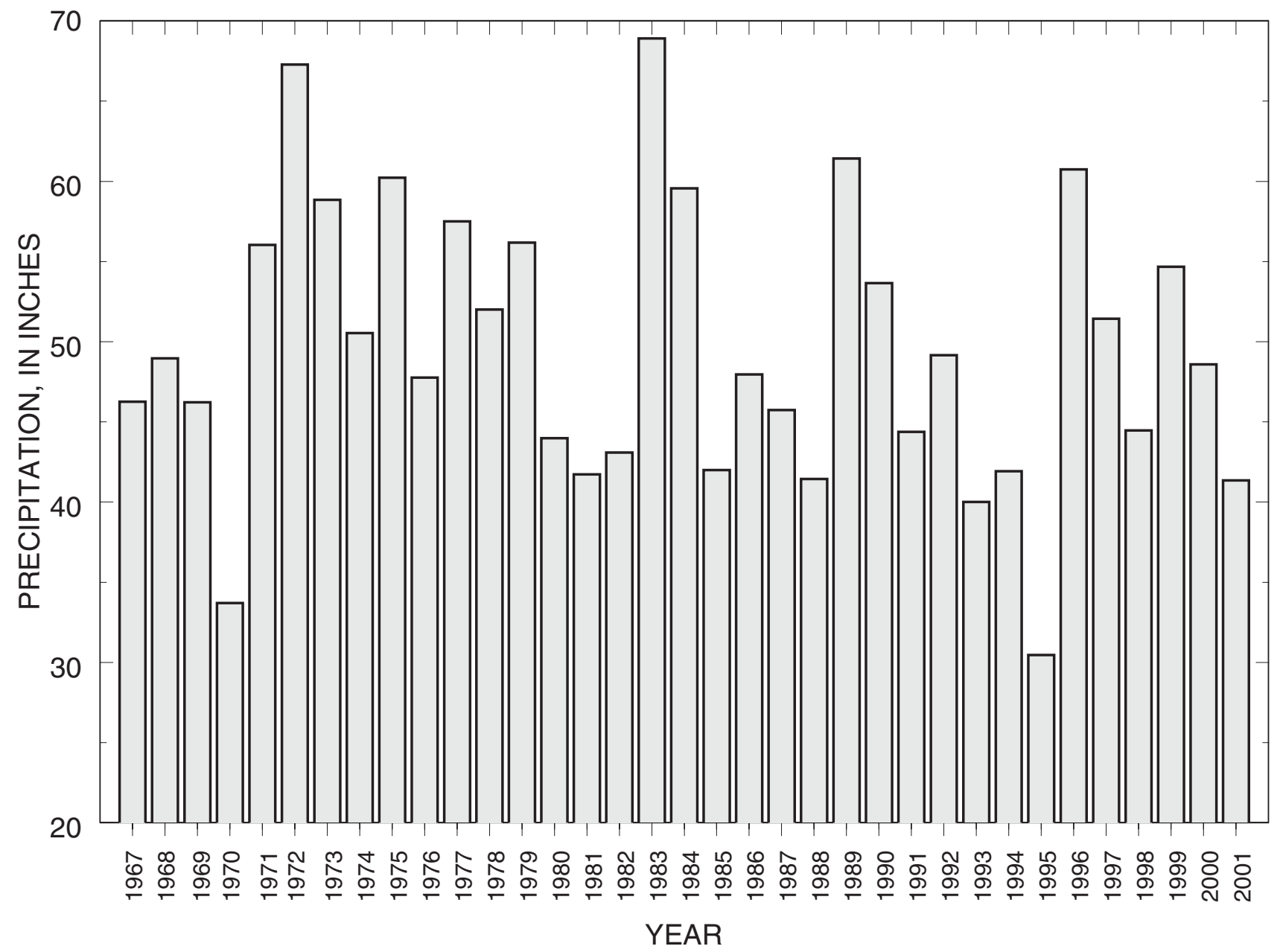

Figure 5. Precipitation at Putnam Lake, Greenwich, Connecticut, 1967-2001. 


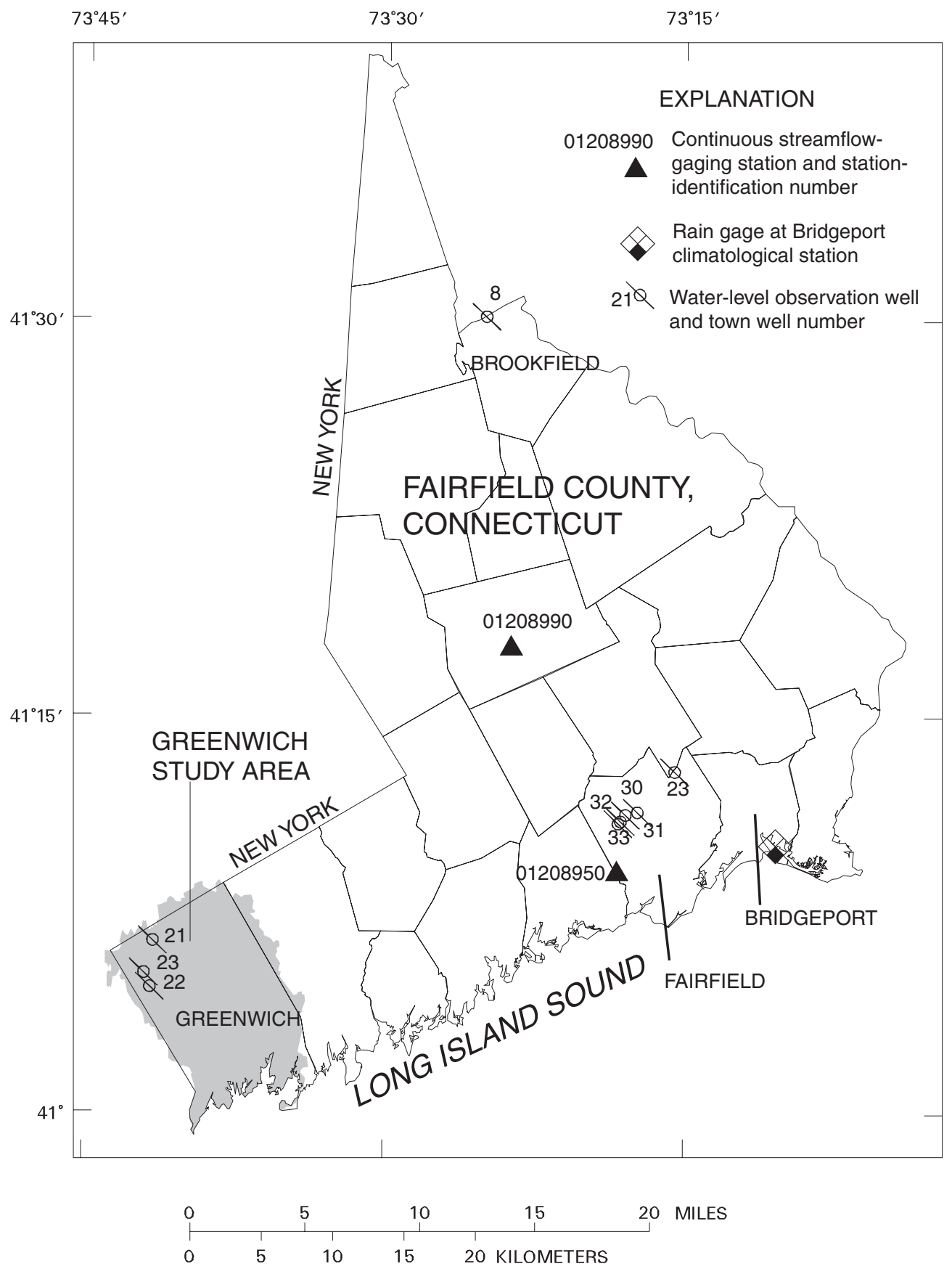

Figure 6. Additional data-collection sites in Fairfield County, Connecticut. 


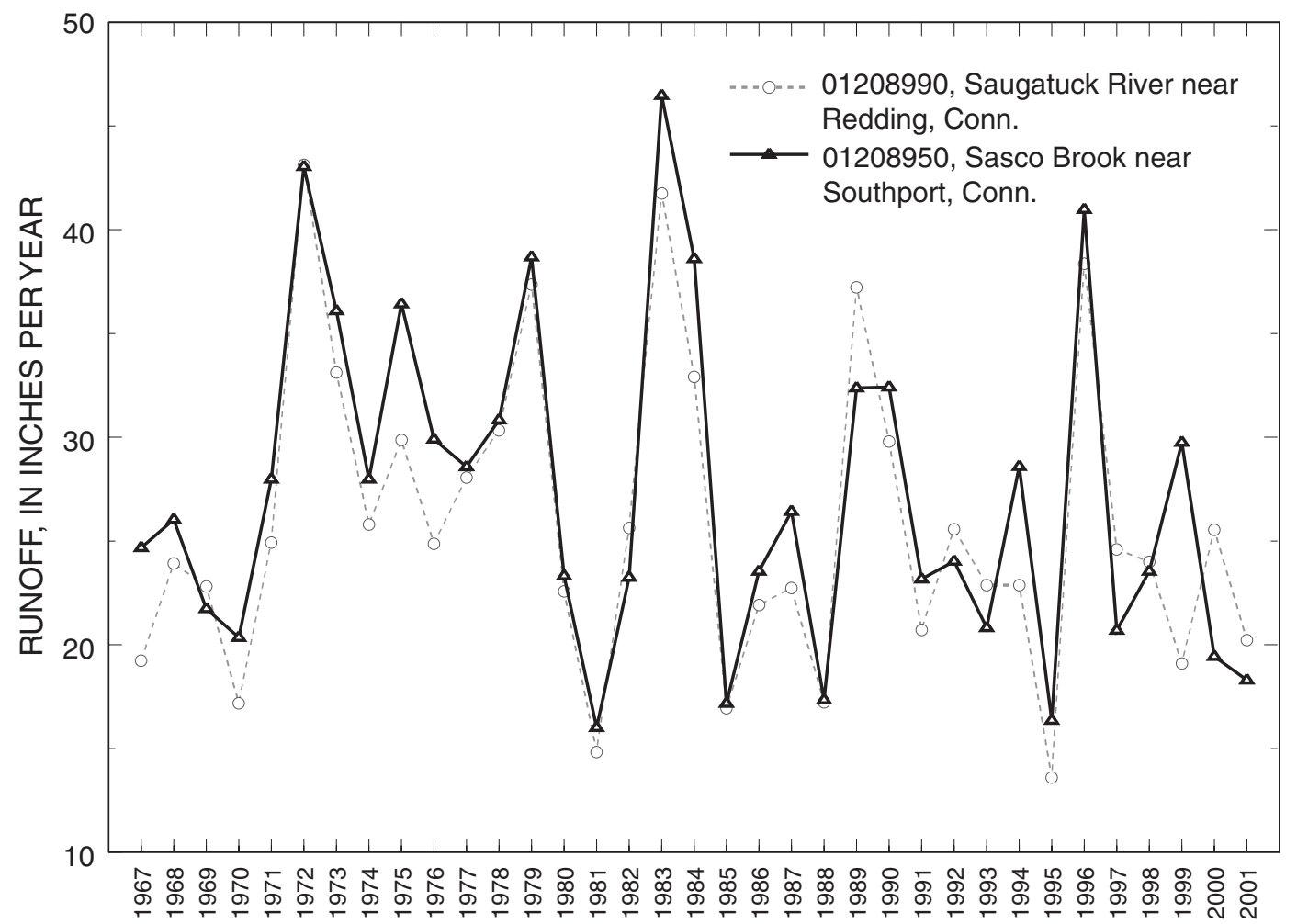

Figure 7. Annual mean runoff at two long-term streamflow-gaging stations near Greenwich, Connecticut, 1967-01.

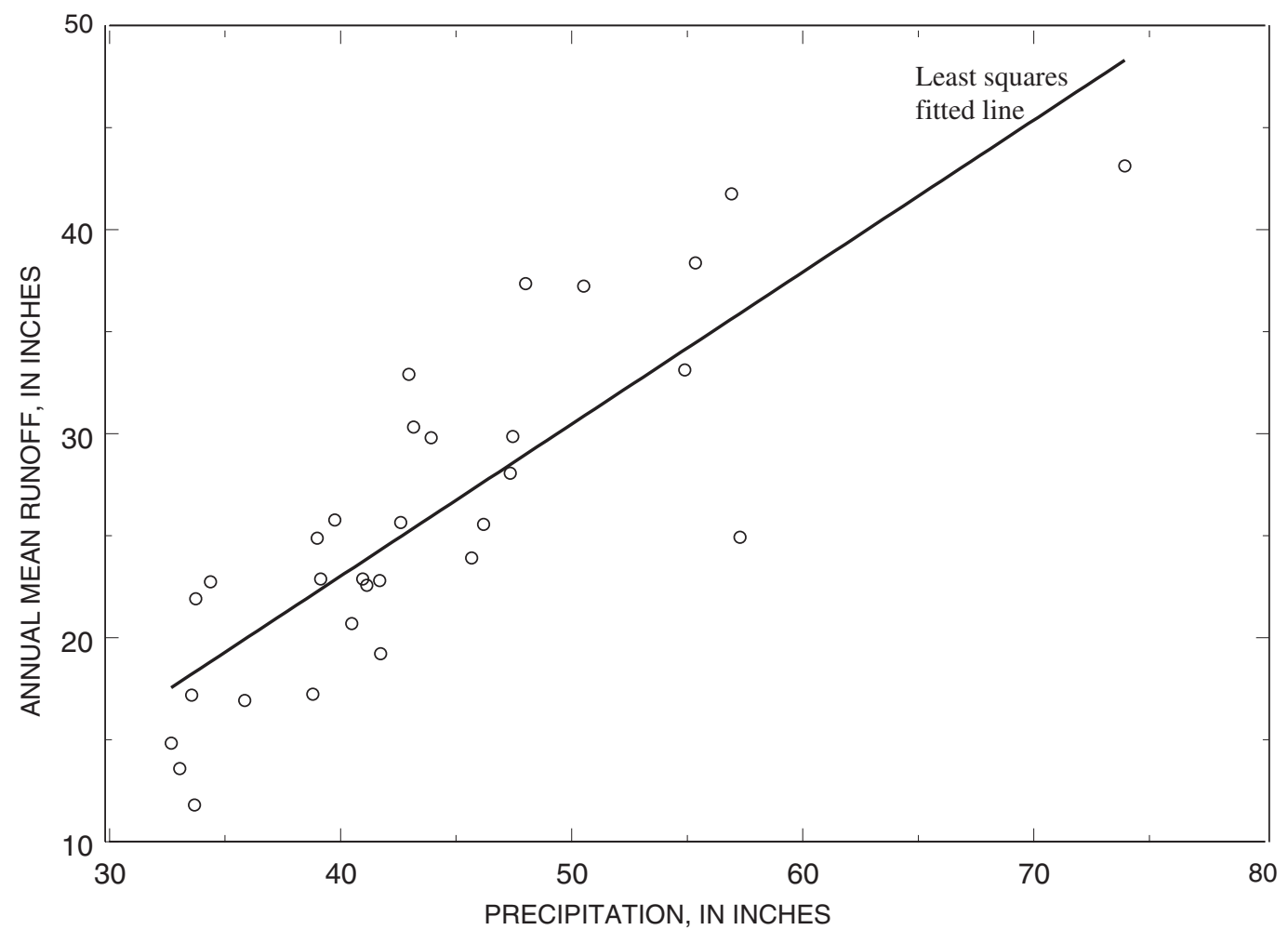

Figure 8. Precipitation at Bridgeport, Connecticut, and runoff at Sasco Brook near Southport, Connecticut (USGS station number 01208950), calendar years 1966-96. 


\section{METHODS OF DATA COLLECTION AND ANALYSIS}

Data collected for this study include (1) streamflow measurements at two continuous record streamflow-gaging stations (2) streamflow measurements at miscellaneous stations, (3) ground-water-level measurements, (4) water-quality samples, and (5) water-use data.

\section{Streamflow Measurements}

Continuous streamflow was measured at two locations (USGS stations 01211699 and 01211110) from February 2001 to September 2002 (fig. 2; table 1) to estimate ground-water recharge, to examine the difference in peak flows among primarily urbanized and primarily forested basins, and to assess the status of streamflow conditions during the study period (200102). Streamflow measurements at selected miscellaneous stations (table 1) were made on October 24-25, 2000 in conjunction with collection of water-quality samples and on April 24-25, 2002 to calibrate a finitedifference ground-water-flow model. Records of streamflow were computed using methods described by Rantz (1982a, b). Streamflow records from February 2001 to September 2002 for stations 01211699 and 01211110 (fig. 2) are in appendix 1.

Table 1. Streamflow measurements, Greenwich area, Connecticut, 2000-2002.

[USGS, U.S. Geological Survey; $\mathrm{mi}^{2}$, square miles; $\mathrm{ft}^{3} / \mathrm{s}$, cubic feet per second; mi, miles; ft, feet; lat., latitude; long, longitude; Type of station: C, continuous; M, miscellaneous. Purpose: QW, water-quality samples collected; C, measurement to calibrate ground-water-flow model; R, measurement to create/maintain rating curve at continuous measurement site]

\begin{tabular}{|c|c|c|c|c|c|c|c|}
\hline $\begin{array}{l}\text { USGS station } \\
\text { identification } \\
\text { number and } \\
\text { stream }\end{array}$ & Tributary to & Location & $\begin{array}{l}\text { Drainage } \\
\text { area } \\
\left(\mathrm{mi}^{2}\right)\end{array}$ & $\begin{array}{l}\text { Type of } \\
\text { station }\end{array}$ & Purpose & $\begin{array}{l}\text { Date of } \\
\text { measure- } \\
\text { ment }\end{array}$ & $\begin{array}{l}\text { Dis- } \\
\text { charge } \\
\left(\mathrm{ft}^{3} / \mathrm{s}\right)\end{array}$ \\
\hline $\begin{array}{l}01211010 \\
\text { Brothers } \\
\text { Brook }\end{array}$ & $\begin{array}{l}\text { Mianus } \\
\text { River }\end{array}$ & $\begin{array}{l}\text { Lat. } 41^{\circ} 03^{\prime} 26^{\prime \prime}, \text { long } 73^{\circ} 35^{\prime} 58^{\prime \prime}, \text { Fair- } \\
\text { field County, at Montgomery Pine- } \\
\text { tum Park (known in Greenwich as } \\
\text { Strickland Brook) }\end{array}$ & 1.39 & $\mathrm{M}$ & $\begin{array}{r}\text { QW } \\
\mathrm{C}\end{array}$ & $\begin{array}{l}10 / 25 / 00 \\
04 / 24 / 02\end{array}$ & $\begin{array}{l}0.173 \\
1.01\end{array}$ \\
\hline $\begin{array}{l}01211040 \\
\text { Greenwich } \\
\text { Creek }\end{array}$ & $\begin{array}{l}\text { Long Island } \\
\text { Sound }\end{array}$ & $\begin{array}{l}\text { Lat. } 41^{\circ} 03^{\prime} 56^{\prime}, \text {, long } 73^{\circ} 36^{\prime} 26^{\prime}, \text {, Fair- } \\
\text { field County, at bridge on Hill } \\
\text { Street near Cos Cob (known in } \\
\text { Greenwich as Beaver Brook) }\end{array}$ & 0.69 & M & $\mathrm{C}$ & $04 / 24 / 02$ & .538 \\
\hline $\begin{array}{l}01211110 \\
\text { Unnamed } \\
\text { tributary }\end{array}$ & $\begin{array}{l}\text { Greenwich } \\
\text { Creek }\end{array}$ & $\begin{array}{l}\text { Lat. } 41^{\circ} 02^{\prime} 34^{\prime \prime}, \text { long } 73^{\circ} 36^{\prime} 59^{\prime \prime}, \text { Fair- } \\
\text { field County, on Old Church Road, } \\
\text { at Cos Cob (known in Greenwich } \\
\text { as West Brothers Brook) }\end{array}$ & 2.19 & $\mathrm{C}$ & $\begin{array}{r}\text { QW } \\
\text { R } \\
\mathrm{R} \\
\mathrm{R} \\
\mathrm{R} \\
\mathrm{R} \\
\mathrm{R} \\
\mathrm{R} \\
\mathrm{R} \\
\mathrm{R} \\
\mathrm{R} \\
\mathrm{R} \\
\mathrm{R} \\
\mathrm{R} \\
\mathrm{R} \\
\mathrm{R} \\
\mathrm{R} \\
\mathrm{R} \\
\mathrm{R} \\
\mathrm{R} \\
\mathrm{R} \\
\mathrm{R} \\
\mathrm{R}\end{array}$ & $\begin{array}{l}10 / 25 / 00 \\
02 / 22 / 01 \\
03 / 13 / 01 \\
03 / 22 / 01 \\
03 / 31 / 01 \\
04 / 19 / 01 \\
05 / 09 / 01 \\
05 / 18 / 01 \\
06 / 04 / 01 \\
06 / 11 / 01 \\
09 / 07 / 01 \\
10 / 09 / 01 \\
10 / 11 / 01 \\
11 / 06 / 01 \\
11 / 30 / 01 \\
04 / 10 / 02 \\
04 / 20 / 02 \\
06 / 07 / 02 \\
06 / 13 / 02 \\
08 / 06 / 02 \\
09 / 24 / 02\end{array}$ & $\begin{array}{c}.389 \\
3.68 \\
37.0 \\
14.0 \\
23.1 \\
3.84 \\
.977 \\
.472 \\
5.27 \\
1.07 \\
.314 \\
.729 \\
.686 \\
.495 \\
1.15 \\
2.98 \\
6.21 \\
36.6 \\
1.85 \\
.040 \\
.842\end{array}$ \\
\hline
\end{tabular}


Table 1. Streamflow measurements, Greenwich area, Connecticut, 2000-2002.-Continued

[USGS, U.S. Geological Survey; $\mathrm{mi}^{2}$, square miles; $\mathrm{ft}^{3} / \mathrm{s}$, cubic feet per second; mi, miles; ft, feet; lat., latitude; long, longitude; Type of station: C, continuous; M, miscellaneous. Purpose: QW, water-quality samples collected; C, measurement to calibrate ground-water-flow model; R, measurement to create/maintain rating curve at continuous measurement site]

\begin{tabular}{|c|c|c|c|c|c|c|c|}
\hline $\begin{array}{l}\text { USGS station } \\
\text { identification } \\
\text { number and } \\
\text { stream }\end{array}$ & Tributary to & Location & $\begin{array}{l}\text { Drainage } \\
\text { area } \\
\left(\mathrm{mi}^{2}\right)\end{array}$ & $\begin{array}{l}\text { Type of } \\
\text { station }\end{array}$ & Purpose & $\begin{array}{l}\text { Date of } \\
\text { measure- } \\
\text { ment }\end{array}$ & $\begin{array}{l}\text { Dis- } \\
\text { charge } \\
\left(\mathrm{ft}^{3} / \mathrm{s}\right)\end{array}$ \\
\hline $\begin{array}{l}01211140 \\
\quad \text { Horseneck } \\
\text { Brook }\end{array}$ & $\begin{array}{l}\text { Long Island } \\
\text { Sound }\end{array}$ & $\begin{array}{l}\text { Lat. } 41^{\circ} 06^{\prime} 50^{\prime \prime}, \text { long } 73^{\circ} 38^{\prime} 00^{\prime \prime}, \text { Fair- } \\
\text { field County, at Lower Cross Road } \\
\text { near Stanwich }\end{array}$ & 0.52 & $\mathrm{M}$ & $\begin{array}{r}\mathrm{QW} \\
\mathrm{C}\end{array}$ & $\begin{array}{l}10 / 25 / 00 \\
04 / 24 / 02\end{array}$ & $\begin{array}{r}0.091 \\
.220\end{array}$ \\
\hline $\begin{array}{l}01211210 \\
\text { Horseneck } \\
\text { Brook }\end{array}$ & $\begin{array}{l}\text { Long Island } \\
\text { Sound }\end{array}$ & $\begin{array}{l}\text { Lat. } 41^{\circ} 05^{\prime} 41^{\prime \prime}, \text { long } 73^{\circ} 35^{\prime} 58^{\prime \prime}, \text { Fair- } \\
\text { field County, at Valley Drive near } \\
\text { Rock Ridge }\end{array}$ & 4.81 & M & QW & $10 / 25 / 00$ & .877 \\
\hline $\begin{array}{l}01211450 \\
\quad \text { Byram River }\end{array}$ & $\begin{array}{l}\text { Long Island } \\
\text { Sound }\end{array}$ & $\begin{array}{l}\text { Lat. } 41^{\circ} 03^{\prime} 26^{\prime \prime}, \text { long } 73^{\circ} 42^{\prime} 18^{\prime \prime}, \text { Fair- } \\
\text { field County, at bridge on Bedford } \\
\text { Road near North Greenwich }\end{array}$ & 9.10 & M & $\mathrm{C}$ & $04 / 25 / 02$ & 4.55 \\
\hline $\begin{array}{l}01211600 \\
\text { Byram River }\end{array}$ & $\begin{array}{l}\text { Long Island } \\
\text { Sound }\end{array}$ & $\begin{array}{l}\text { Lat. } 41^{\circ} 03^{\prime} 38^{\prime \prime}, \text { long } 73^{\circ} 40^{\prime} 41^{\prime \prime}, \text { Fair- } \\
\text { field County, at bridge on Sher- } \\
\text { wood Avenue, at Riversville }\end{array}$ & 11.7 & M & $\mathrm{C}$ & $10 / 24 / 00$ & 1.87 \\
\hline $\begin{array}{l}01211699 \\
\text { East Branch } \\
\text { Byram River }\end{array}$ & $\begin{array}{l}\text { Byram } \\
\text { River }\end{array}$ & $\begin{array}{l}\text { Lat. } 41^{\circ} 05^{\prime} 58^{\prime \prime}, \text { long } 73^{\circ} 41^{\prime} 02^{\prime \prime}, \text { Fair- } \\
\text { field County, below Lake Mead, } \\
200 \mathrm{ft} \text { upstream from John Street, } \\
\text { at Round Hill (known in Green- } \\
\text { wich as Middle Branch Byram } \\
\text { River) }\end{array}$ & 1.65 & $\mathrm{C}$ & $\begin{array}{r}\text { QW } \\
\mathrm{R} \\
\mathrm{R} \\
\mathrm{R} \\
\mathrm{R} \\
\mathrm{R} \\
\mathrm{R} \\
\mathrm{R} \\
\mathrm{R} \\
\mathrm{R} \\
\mathrm{R} \\
\mathrm{R} \\
\mathrm{R} \\
\mathrm{R} \\
\mathrm{R} \\
\mathrm{R}, \mathrm{C} \\
\mathrm{R} \\
\mathrm{R} \\
\mathrm{R} \\
\mathrm{R}\end{array}$ & $\begin{array}{l}10 / 24 / 00 \\
02 / 22 / 01 \\
03 / 13 / 01 \\
03 / 20 / 01 \\
04 / 19 / 01 \\
05 / 18 / 01 \\
06 / 04 / 01 \\
06 / 11 / 01 \\
09 / 07 / 01 \\
09 / 28 / 01 \\
11 / 06 / 01 \\
11 / 30 / 01 \\
01 / 03 / 02 \\
02 / 05 / 02 \\
04 / 10 / 02 \\
04 / 24 / 02 \\
05 / 20 / 02 \\
06 / 07 / 02 \\
08 / 06 / 02 \\
09 / 24 / 02\end{array}$ & $\begin{array}{c}.393 \\
3.83 \\
13.8 \\
4.64 \\
3.50 \\
.654 \\
2.89 \\
.839 \\
.029 \\
1.60 \\
.19 \\
.620 \\
.289 \\
.687 \\
1.98 \\
1.09 \\
5.53 \\
25.6 \\
.16 \\
.069\end{array}$ \\
\hline $\begin{array}{l}01212100 \\
\text { East Branch } \\
\text { Byram River }\end{array}$ & $\begin{array}{l}\text { Long Island } \\
\text { Sound }\end{array}$ & $\begin{array}{l}\text { Lat. } 41^{\circ} 03^{\prime} 39^{\prime}, \text {, long } 73^{\circ} 40^{\prime} 31^{\prime \prime}, \text { Fair- } \\
\text { field County, at bridge on } \\
\text { Riversville Road just downstream } \\
\text { from Merritt Parkway, } 0.2 \mathrm{mi} \\
\text { upstream from mouth }\end{array}$ & ${ }^{1} 7.4$ & M & QW & $10 / 24 / 00$ & 1.86 \\
\hline $\begin{array}{l}01212550 \\
\text { Unnamed } \\
\text { tributary }\end{array}$ & $\begin{array}{l}\text { Byram } \\
\text { River }\end{array}$ & $\begin{array}{l}\text { Lat. } 41^{\circ} 01^{\prime} 39^{\prime}, \text {, long } 73^{\circ} 39^{\prime} 41^{\prime}, \text {, Fair- } \\
\text { field County, upstream of bridge } \\
\text { on Pemberwick Road (known in } \\
\text { Greenwich as Pemberwick Brook) }\end{array}$ & 1.4 & M & $\mathrm{C}$ & $04 / 25 / 02$ & .839 \\
\hline $\begin{array}{l}01212600 \\
\text { Byram River }\end{array}$ & $\begin{array}{l}\text { Long Island } \\
\text { Sound }\end{array}$ & $\begin{array}{l}\text { Lat. } 41^{\circ} 01^{\prime} 38^{\prime \prime}, \text { long } 73^{\circ} 39^{\prime} 41^{\prime \prime}, \text { Fair- } \\
\text { field County, downstream of } \\
\text { unnamed tributary at Pemberwick }\end{array}$ & ${ }^{1} 23.6$ & M & $\mathrm{C}$ & $04 / 25 / 02$ & 13.6 \\
\hline
\end{tabular}

${ }^{1}$ Drainage area does not include basins diverted to Putnam Lake (fig. 2). 


\section{Water-Level Measurements}

Three wells (table 2) were installed in the East Branch of the Byram River Basin, using air-rotary drilling techniques, to monitor water levels and ground-water storage in the bedrock aquifer. The wells were installed at different topographic positions in the watershed to evaluate the magnitude of water-level fluctuations in different parts of the ground-water-flow system (GW-21 on the hilltop on the drainage divide, GW-23 on the hillside, and GW-22 in the bottom of the valley, figs. 2,99). This approach of installing wells in different parts of the ground-water-flow system was discussed by Melvin (1986) and has been implemented in many basins in Connecticut with USGS streamflowgaging stations. Water-level fluctuations generally are greater on hilltops and hillsides, where ground-waterflow gradients are low. Water-level fluctuations in the valley bottom typically are small, because these tend to be areas of ground-water discharge, and ground-waterflow gradients are high.

Water levels were measured sporadically beginning in September 2001; water levels were monitored continuously using submersible pressure transducers with data loggers from November 20, 2001, to October 2002. Data on daily water levels were published by Morrison and others (2003).

Water levels also were measured in 36 domestic wells on April 16-20, 2002 to calibrate the groundwater-flow model. Wells were selected from a list of voluntary homeowners who were interested in participating in the study. Wells were located using a global positioning system (GPS), and the altitude of the land surface was determined from 2-ft contour maps provided by the town of Greenwich. In addition, water levels measured by well drillers were obtained from
402 well-completion reports as part of calibrating the ground-water-flow model.

\section{Water-Quality Samples}

Water-quality samples were collected from seven sites (ig. 2; table 1) during base-flow conditions on October 24-25, 2000. Samples were collected during a base-flow period to ensure that streams contained primarily ground-water discharge. These samples represented an integrated sample of groundwater quality in basins with different land-use characteristics. Samples were collected using methods described by Wilde and Radtke (1998), Wilde and others (1998a-c), and Wilde and others (1999a, b) and were analyzed at the USGS laboratory in Denver, Colorado, for major ions, dissolved trace elements, nutrients, volatile organic compounds (VOCs), pesticides, and indicator bacteria. Water-quality analyses were reported in Morrison and others (2002). An additional sample was collected at site 01211110 (fig. 2) for experimental analysis of pharmaceuticals, hormones, and other organic wastewater contaminants, and analyzed using methods described in Kolpin and others (2002). This sample was collected to determine if compounds associated with septic-system waste were entering streams from ground water.

\section{Water-Use Data}

Water-use data were compiled from public water suppliers for calendar year 2000 (David Medd, Aquarion Water Company of Connecticut, written commun., 2002). These data were used to create a statistical model of water use at residences with private wells and to estimate return flow from private septic systems.

Table 2. Wells in the East Branch Byram River Basin, Greenwich, Connecticut.

[USGS, U.S. Geological Survey]

\begin{tabular}{cccccccc}
\hline $\begin{array}{c}\text { USGS local } \\
\text { well } \\
\text { identifier }\end{array}$ & $\begin{array}{c}\text { station identification } \\
\text { number }\end{array}$ & $\begin{array}{c}\text { Latitude } \\
\text { (NAD83) }\end{array}$ & $\begin{array}{c}\text { Longitude } \\
\text { (NAD83) }\end{array}$ & $\begin{array}{c}\text { Altitude } \\
\text { (feet) }\end{array}$ & $\begin{array}{c}\text { Depth of } \\
\text { well } \\
\text { (feet) }\end{array}$ & $\begin{array}{c}\text { Depth to } \\
\text { bedrock } \\
\text { (feet) }\end{array}$ & $\begin{array}{c}\text { Depth to } \\
\text { bottom of } \\
\text { casing }\end{array}$ \\
\hline CT-GW 21 & 410628073413301 & $41^{\circ} 06^{\prime} 28.4^{\prime \prime}$ & $73^{\circ} 41^{\prime} 32.6^{\prime \prime}$ & 465 & 350 & 11 & 18.7 \\
CT-GW 22 & 410443073414101 & $41^{\circ} 04^{\prime} 43.3^{\prime \prime}$ & $73^{\circ} 41^{\prime} 40.7^{\prime}$ & 222 & 250 & 14 & 18.6 \\
CT-GW 23 & 410515073415901 & $41^{\circ} 05^{\prime} 15^{\prime \prime}$ & $73^{\circ} 41^{\prime} 59.5^{\prime \prime}$ & 365 & 250 & 9 & 17.8 \\
\hline
\end{tabular}



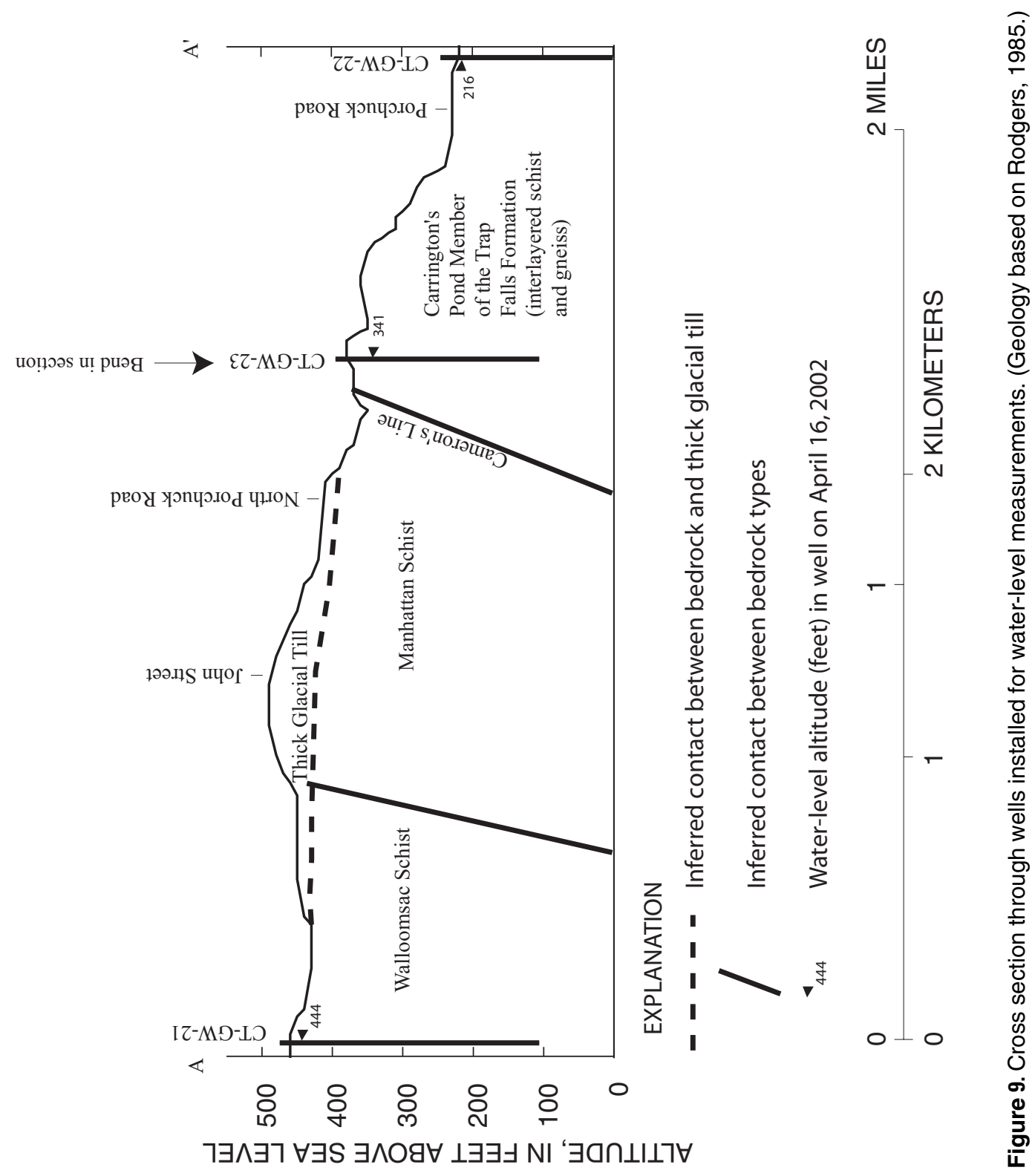


\section{GROUND-WATER RECHARGE IN THE GREENWICH AREA}

In the Greenwich area, natural ground-water recharge to bedrock aquifers is derived primarily from precipitation that infiltrates from the land surface to the water table. Other natural sources of recharge include loss of water from lakes, wetlands, and streams. Previous studies in Connecticut have shown that there are differences in ground-water recharge in areas covered with till compared to areas covered with glacial stratified deposits. These differences have been observed in the base-flow component of streamflow (ground-water runoff). Mazzaferro and others (1979) determined the following mathematical relation between geology and ground-water runoff based on work by Thomas (1966):

$$
Y=0.6 X+35
$$

where

$$
\begin{aligned}
& Y=\text { Ground-water runoff, as a ratio to } \\
& \text { total basin runoff, and } \\
& X=\text { Percentage of the basin underlain by } \\
& \text { coarse-grained stratified drift (glacial strati- } \\
& \text { fied deposits). }
\end{aligned}
$$

Recharge rates calculated with this equation represent the total recharge in the basin, but do not describe how much recharge actually infiltrates to the bedrock aquifer from the glacial material. For instance, a large percentage of recharge to till areas discharges directly from the till into small nearby streams and intermittent watercourses during wet periods. Under natural conditions, most recharge to glacial stratified deposits does not enter bedrock, because glacial stratified deposits are mostly in valley-bottom locations. These areas are associated with ground-water discharge; therefore, ground water is more likely to flow upward from the bedrock aquifer to the glacial stratified deposits than downward from the surficial deposits to the bedrock aquifer. Under stressed conditions, such as those that take place when wells in the bedrock aquifer are pumped, water in the till and glacial stratified deposits, which normally would have discharged to a local surface-water body, may be drawn into the bedrock aquifer and into wells.

\section{Factors Affecting Ground-Water Recharge}

Factors other than geologic properties may affect recharge rates locally and temporally. Annual and longterm variability and timing of precipitation and subsequent runoff from a basin are very important in determining recharge rates. In Connecticut, recharge takes place primarily during the nongrowing season from October to May (Melvin, 1986) although precipitation is generally distributed evenly throughout the year. In a typical year, ground-water levels begin to rise in October, because there is more recharge to the aquifer than discharge to streams. During the growing season, water levels typically follow a downward trend because of evapotranspiration and depletion of soil moisture, despite temporary peaks caused by large rainfall events. A lack of precipitation during the nongrowing season can cause lower than normal water levels in the aquifer even in a year with above-normal precipitation during the growing season. In addition, water-level fluctuations are likely to be larger in upland areas than in valley bottoms; therefore, the effects of drought conditions may be more pronounced in the upland areas.

In areas where the water table is at land surface, recharge is rejected as surface runoff (Kontis, 2001). Channelized or unchanneled surface runoff from till deposits may be another important source of recharge to glacial stratified deposits (Kontis, 2001). The natural drainage patterns, the degree to which channelized flow takes place, and the position of the water table during the nongrowing season may affect local recharge rates in any basin.

Other factors that may affect natural recharge include slope, vegetation cover, and local variations in geology and soil moisture. For example, Bauer and Mastin (1997) showed that areas with coniferous forest may have less ground-water recharge than areas with deciduous forest, due to retention and evaporation of rain and snow from the evergreen canopy.

In a developed area such as Greenwich, human activities can affect recharge rates and can change the ground-water budget of a particular basin. Development adds impervious surfaces that can impede natural recharge. Ground-water withdrawals can reduce the base flow of streams or increase the recharge from surface-water bodies and wetlands. Reduction in ground-water levels in areas where the water table is at land surface also may increase recharge from precipitation. The discharge of wastewater through septic 
systems can affect ground-water-flow patterns, and, in areas like Greenwich, can be an additional source of recharge if the water is imported from public watersupply reservoirs inside or outside the basin.

Additional recharge may be obtained from leaking water mains, storm sewers, and sanitary sewers, and ground-water withdrawals may occur from infiltration into sanitary sewer lines. The amount of water entering and leaving the ground-water system from these sources is difficult to quantify, but due to the aging water and sewer infrastructure in Greenwich, it is likely that some amount of water is gained or lost from these sources. A study of these issues would lead to enhanced understanding of the ground-water budget in the Greenwich area.

\section{Ground-Water Recharge and Discharge, 2001-02}

Ground-water recharge and discharge can be observed in the hydrographs of ground-water levels in wells GW-21, 22, and 23 (fig. 10), and in records of streamflow (appendix 1). Ground-water recharge during the winter of 2001-02 was delayed in wells GW 21 and 23 by a lack of precipitation. Ground-water levels began to rise in well GW-23 during November 2001, but did not rise in well GW-21 until February 2002 (fig. 10). The delay probably was caused by below-normal precipitation. Precipitation from October 2001 to February 2002 at nearby Putnam Lake was 8.11 in., compared to the 20 -year average of 18.58 in. for these months during 1982-01 (David Medd, Aquarion Water Company of Connecticut, written commun., 2002). The highest water levels in the three wells installed for this study were during May 2002.

Water levels generally declined in all three wells during the summer of 2002; however, only GW-23 responded to summer precipitation. It may be that some additional source of recharge in this part of the basin allows water into the aquifer. One hypothesis is that an intermittent stream about $50 \mathrm{ft}$ from this well affects ground-water recharge-during the spring, when this stream is flowing, it may be a conduit for ground-water discharge; when this stream dries up, it may become a source for ground-water recharge from upland surfacewater runoff collected during storms. Water-level fluctuations in well GW-22 (in the valley bottom of the basin) were much smaller than fluctuations in GW-21 or GW-23, as expected, due to ground-water inflow from upgradient areas.
Stream base flow can be equal to ground-water recharge during periods when there is no net change in ground-water storage. Ground-water discharge to a stream can be determined by the separation of base flow from a streamflow hydrograph. Streamflow was continuously monitored (appendix 1) at two locations (fig. 2) from March 2001 to September 2002. A baseflow separation was conducted at station 01211699 to determine the ground-water discharge from this basin during April 2001-September 2002. The computer hydrograph separation program "PART" developed by Rutledge (1997) was used to estimate the quarterly ground-water runoff. (fig. 11).

During April-December 2001, the total runoff calculated for station 01211699 was 8.48 in. This compares with $8.60 \mathrm{in}$. of runoff at nearby Sasco Brook (station 01208950; fig. 6) during the same period. The mean annual runoff for April-December at Sasco Brook from 1967-2001 was 16.2 in., indicating that most of 2001 was drier than average.

At station 01211699 in Greenwich, the results of hydrograph separation from "PART" (fig. 11) indicate that most ground-water discharge from this basin took place from April to June (4.5 in.) with a very small amount (1.5 in.) from July to December. Ground-water runoff (6.0 in.) represented 70 percent of the total runoff from April to December 2001.

Data from USGS streamflow-gaging stations commonly are reported by water year, ${ }^{1}$ which represents the annual water cycle. If the baseflow-separation data from 01211699 are calculated on the basis of water year 2002 (October 2001 to September 2002), the total base flow for this period was $7.81 \mathrm{in}$. and the total runoff was 12.21 in (fig 10); therefore, base flow was about 64 percent of the total annual runoff. In comparison, the mean annual runoff at Sasco Brook (station 01208950; fig. 6) was 25.7 in. from 1967-2001. There probably was more base flow than recharge for water year 2002 because ground water that was in storage before the water year began was discharged and because 2002 was drier than normal.

\footnotetext{
${ }^{1} \mathrm{~A}$ water year is defined as the 12 -month period October 1 through September 30. The water year is designated by the calendar year in which it ends and which includes 9 of the 12 months. Thus, the year ending September 30, 2002 is called the 2002 water year.
} 
PRECIPITATION, IN INCHES

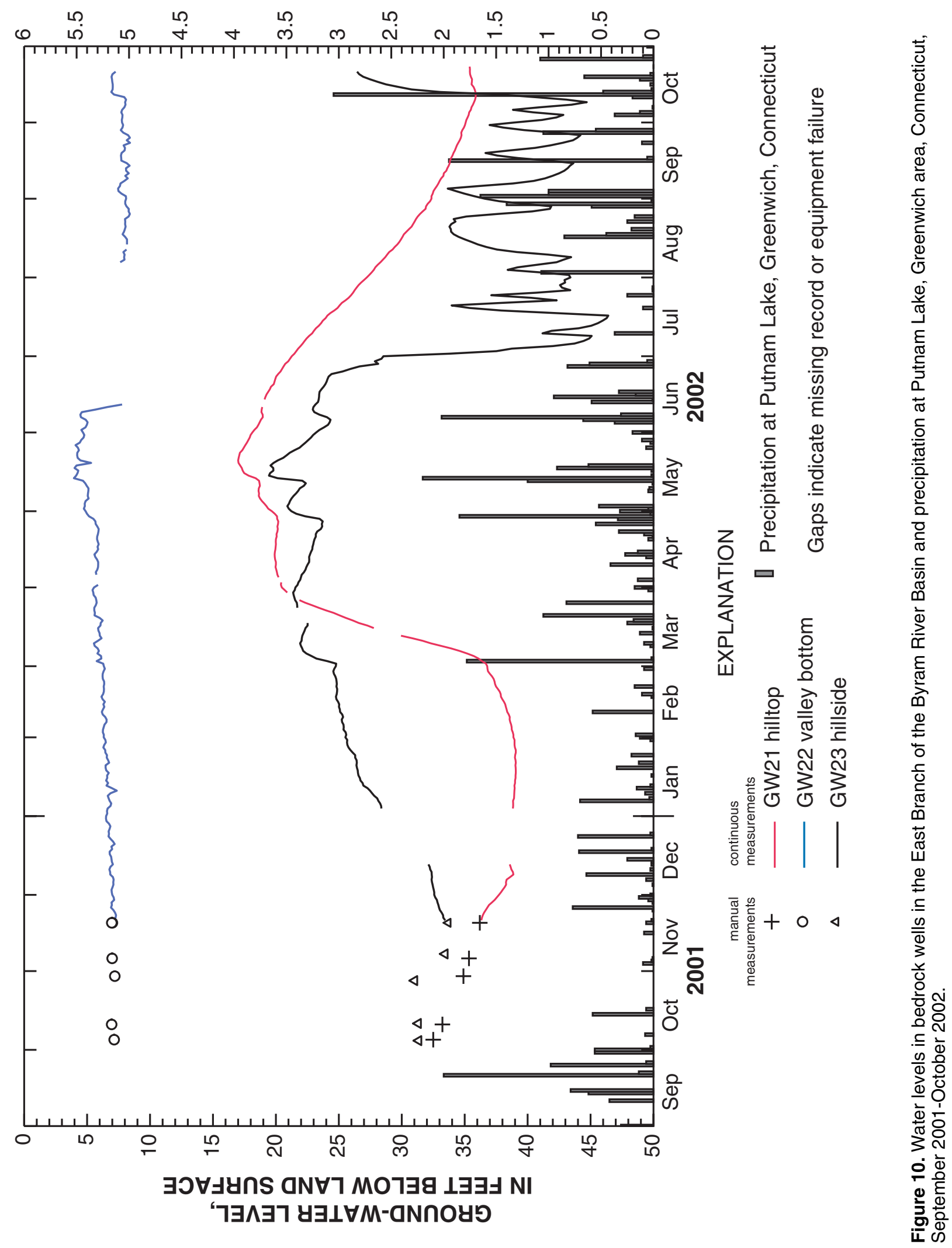




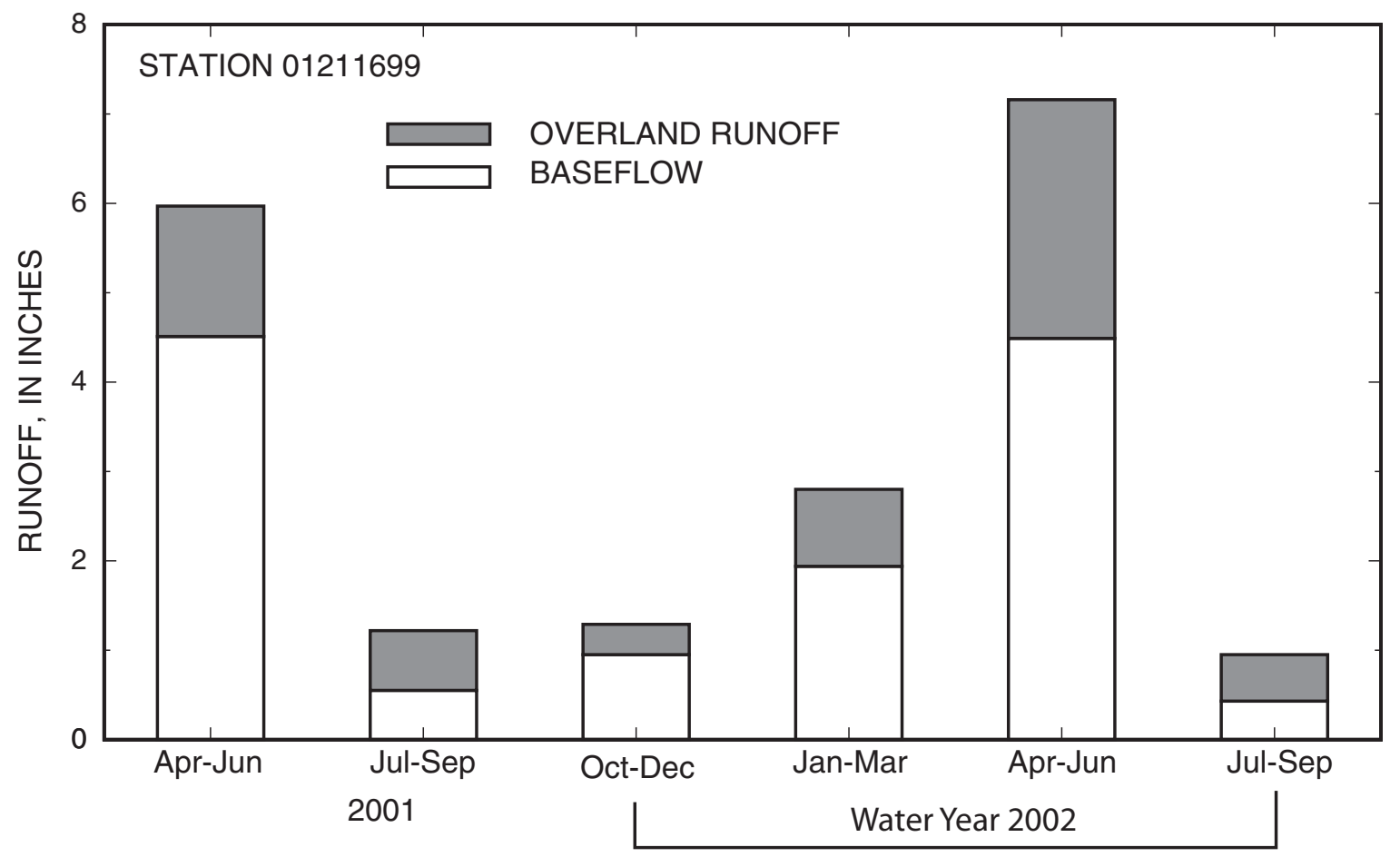

Figure 11. Quarterly base flow at U.S. Geological Survey streamflow-gaging station number 01211699, East Branch Byram River below Lake Mead at Round Hill, Connecticut.

\section{WATER USE IN THE GREENWICH AREA}

Residential water use was estimated for basins in Greenwich to (1) determine water-use patterns, (2) provide data for input into a finite-difference groundwater-flow model, as either water withdrawals from wells or as return flow in areas with septic systems and public water supply, and (3) estimate consumptive water use, with respect to average rates of ground-water recharge.

Ground-water withdrawals for residences with private wells in Greenwich were estimated by evaluating water-use data and geographic information system (GIS) characteristics of residences with public water supply for calendar year 2000 and creating loglinear ordinary least-squares (OLS) regression models to estimate average daily water use, average summer water use, and average daily winter water use. Predictions of water use and confidence intervals were aggregated by drainage basin (appendix 2).

Additional estimates of water use for golf courses, commercial buildings, schools, churches and other government or institutional buildings, which would be necessary to determine total water use for each basin, would be useful to understand the full effect of water use on downstream resources, but were beyond the scope of this study.

\section{Water Use at Residences with Public Water Supply}

The water-use data (meter readings) for individual domestic users obtained from Aquarion Water Company of Connecticut for calendar year 2000 were matched to addresses in the town of Greenwich property GIS database. Average daily water use was calculated for each property with public water supply by summing the quarterly (or more frequent) meter readings and dividing by 365 days. Average daily summer water use was calculated by summing meter readings from April to September, and values for average daily winter water use were calculated by summing readings from January to March and October to December. These values were divided by 182.5 days, or one-half of a year. A subset of these properties had data that could be extracted only seasonally, because of water billing cycles, or meter readings that were not recorded at least quarterly; therefore, a smaller number of observations were used to predict winter and summer water use than were used for average daily water use. Data were summarized initially by property size (table 3). 
Table 3. Median daily water use, and median daily seasonal water use by property size, in calendar year 2000 at selected residences with public water supply.

[gal/d, gallons per day; <, less than; >, greater than]

\begin{tabular}{|c|c|c|c|c|c|c|}
\hline \multirow[t]{2}{*}{$\begin{array}{l}\text { Residential } \\
\text { property size } \\
\text { (acres) }\end{array}$} & \multicolumn{2}{|c|}{$\begin{array}{l}\text { Median daily water use } \\
\text { calendar year } 2000 \\
\text { (based on average daily use at } \\
\text { individual properties) }\end{array}$} & \multicolumn{2}{|c|}{$\begin{array}{c}\text { Median daily water use, } \\
\text { April-September } 2000 \\
\text { (based on average daily } \\
\text { summer use at individual } \\
\text { properties) }\end{array}$} & \multicolumn{2}{|c|}{$\begin{array}{l}\text { Median daily water use, } \\
\text { January-March } 2000 \text { and } \\
\text { October-December } 2000 \\
\text { (based on average daily winter } \\
\text { use at individual properties) }\end{array}$} \\
\hline & (gal/d) & $\begin{array}{c}\text { Number of } \\
\text { households }\end{array}$ & (gal/d) & $\begin{array}{c}\text { Number of } \\
\text { households }\end{array}$ & (gal/d) & $\begin{array}{c}\text { Number of } \\
\text { households }\end{array}$ \\
\hline$<0.5$ & 219 & 309 & 230 & 240 & 204 & 240 \\
\hline$>.5-1$ & 295 & 342 & 324 & 251 & 225 & 251 \\
\hline$>1-2$ & 357 & 1,297 & 410 & 1,011 & 275 & 1011 \\
\hline$>2-4$ & 535 & 828 & 704 & 723 & 385 & 723 \\
\hline$>4$ & 1,082 & 112 & 1389 & 89 & 848 & 89 \\
\hline
\end{tabular}

Typical water use in Connecticut is estimated to be about $76 \mathrm{gal} /$ person/d (Solley and others, 1998). Based on data compiled for this report (table 3), it is apparent that water use in the Greenwich area may be larger than what is typical, depending on the type of development. In areas with less than 1-acre lot size, per capita use is about $113 \mathrm{gal} /$ person/d or less. In areas with larger lots, per capita use could be as high as 416 $\mathrm{gal} / \mathrm{person} / \mathrm{d}$ (based on table 3 values and assuming an average of 2.6 persons per household (U.S. Department of Commerce, 1991)).

\section{Log-Linear Regression Models of Residential Water Use}

The regression models that were used to predict water use for residences with private wells were of the form

$$
\begin{aligned}
& \ln (W U)=\beta_{0}+\beta_{1}\left(X_{1}\right)+\beta_{2}\left(X_{2}\right)+\beta_{3}\left(X_{3}\right) \ldots \\
& \beta_{n}\left(X_{n}\right)+E
\end{aligned}
$$

where

$W U$ is water use, in gallons per day,

$\beta_{0}$ is an intercept,

$\beta_{1}, \beta_{2}, \beta_{3}$ are coefficients,

$X$ is an independent variable, and

$E$ is a random error.
Information from the Greenwich GIS database that was compiled for each property included the presence and size of an outdoor swimming pool, the lot size, the number and total footprint of buildings, and the area of the lot that was forested. The area of forest cover was subtracted from the total lot area to create a variable related to lawn size. These variables were chosen because of their availability and the hypothesis that properties with large acreage, swimming pools, large or numerous buildings, and large lawns use more water. A study done by the American Water Works Association Research Foundation in several metropolitan areas in the United States determined that these are important factors in determining residential water use (American Water Works Association Research Foundation, 1999). A similar approach was undertaken in this study.

\section{Variable Selection}

The GIS information that was compiled was tested in different combinations as variables in a multiple linear-regression model to predict the natural $\log$ of average daily water use for each property with public water-supply information. A log-transformation of the response variable (water-use data) was necessary because the data appear to be log-normally distributed. Variables (tables 4, $\underline{5}$, and $\underline{6}$ ) were selected on the basis of physical plausibility, the evaluation of $\mathrm{R}^{2}$ (coefficient of determination), the distribution of residuals, 
and whether or not the variable was statistically significant at the 95-percent confidence interval. Regression models were created for average daily water use, average summer water use, and average winter water use.

Selected variables (tables $4, \underline{5}$, and $\underline{6}$ ) were similar for all three regression models. The variables as a group have some predictive ability and are highly significant, but the coefficients of determination $\left(\mathrm{R}^{2}\right)$ for each model are low and indicate that additional variables would be useful. For example, a variable for the number of residents per household would help explain additional error; however, many of the variables for predicting water use probably are socioeconomic and therefore are difficult to quantify or are unavailable. Model residuals are generally normally distributed (figs. 12A-C). This indicates that it is reasonable to apply confidence intervals to water-use predictions made with these models.

\section{Prediction of Residential Water Use in Areas with Domestic Wells}

A major assumption in using the regression method to predict water use for residences with private wells is that residences with wells use water at similar rates to similar residences with public water supply. It is possible that water use in homes with private wells may differ from those with public water supply. For instance, homeowners with wells may use less water indoors because of the lower water pressure that is sometimes associated with private domestic water systems, or may be more or less inclined to fill or top off swimming pools, to water lawns, or to use water for other landscaping purposes.

To use the OLS regression model described above for making water-use predictions, an algorithm was applied to correct for retransformation bias in converting the predictions from natural log space. Data that are retransformed from log space will not be normally distributed; therefore, predictions and the associated confidence intervals will be biased (Helsel and Hirsch, 1992). The method used to account for retransformation bias is the Minimum Variance Unbiased Estimator (MVUE) (Cohn and others, 1989).
A computer program was written (Gregory Schwarz, U.S. Geological Survey, written commun. 2002) to run the OLS regression model and make predictions using the MVUE. The program sorts predictions by water-use type (private well and septic system, or public water supply and septic system), aggregates data by basin (fig. 13), and computes the 90percent confidence interval of the aggregated values (_ 2). The program uses actual water-use data in areas with public water supply and private septic systems, or predicts water use for properties in the public watersupply area that were not matched to the GIS data. Return flow from septic systems (fig. 14) was assumed to be equivalent to the winter rate of water use. Return flow from septic systems in areas with public water supply were separated from return flow in areas with private wells, because this is generally an outside source of additional recharge to the aquifer.

Predictions for areas outside the Greenwich town boundaries were made using different methods because of the availability and comparability of GIS datasets. Water-use predictions were made for the Stamford part of the study area using the same water-use model as for Greenwich, because the City of Stamford has comparable GIS datasets to Greenwich, except for forest cover. The unforested part of each property in the study area in Stamford was digitized from high-resolution, digital aerial photographs. Water-use estimates for residential properties in the Westchester County part of the study area were made based on property size only, because GIS data layers were unavailable. The number of residential properties of each size in each basin were summarized from town of North Castle, New York assessor's records. Values from table 3 were applied to these properties. These estimates are subject to an unknown amount of error. The error will be less in basins where the estimate of water use for the Westchester part of the basin is within the 90-percent confidence interval for water use in the rest of the basin (appendix 2).

Average annual residential ground-water withdrawals from the study area are estimated to total 2.1 $\mathrm{Mgal} /$ year (appendix 2). Return flow from septic systems at residences served by public water supply was estimated using the winter water use model to total $1.4 \mathrm{Mgal} /$ year. 


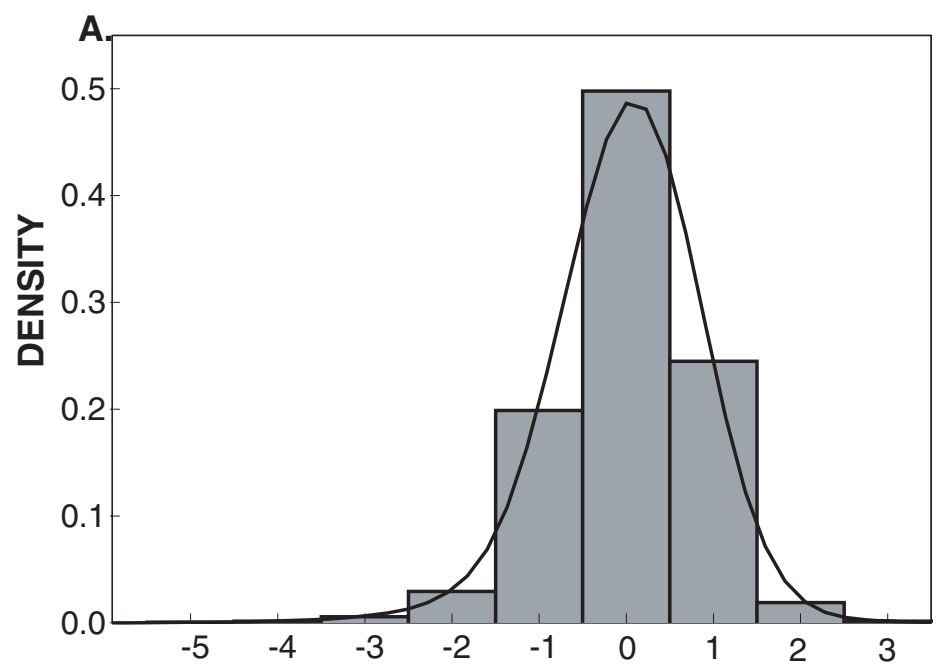

B.

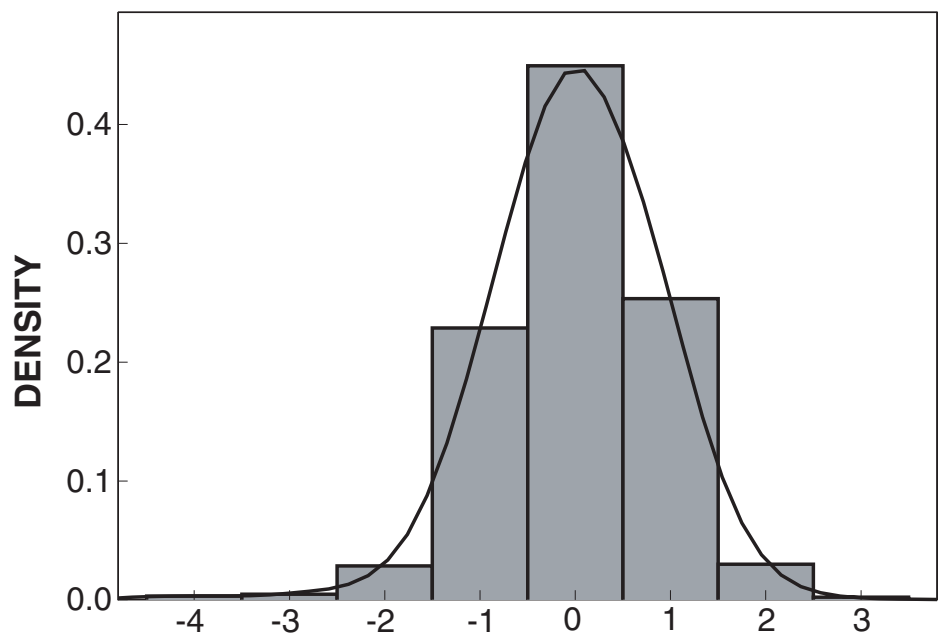

C.

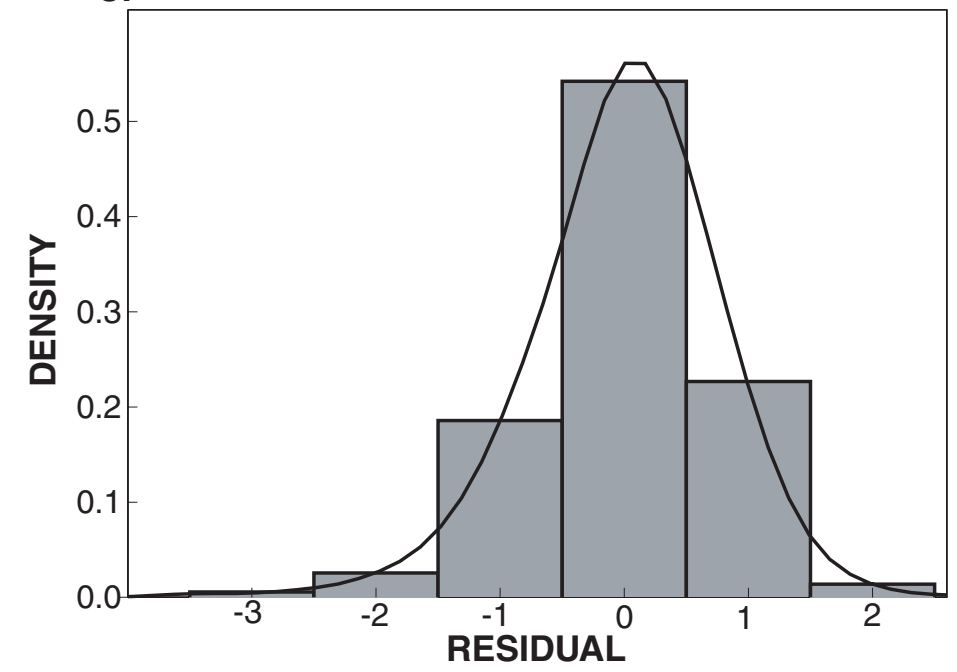

Figure 12. Frequency distribution for residuals and the "best-fit" normal distribution approximation for $(A)$ average daily water use, (B) average daily summer water use, and (C) average daily winter water use, Greenwich area, Connecticut. 
Table 4. Parameter estimates, standard errors, t-statistics, and p-values for multiple linear regression model of average daily water use at residences with public water supply, calendar year 2000, Greenwich, area, Connecticut.

[Coefficient of determination $\left(\mathrm{R}^{2}\right)=0.25$ ]

\begin{tabular}{llcccc}
\hline \multicolumn{1}{c}{ Variable } & \multicolumn{1}{c}{ Units } & $\begin{array}{c}\text { Parameter } \\
\text { estimate }\end{array}$ & Standard error & t-statistic & p-value \\
\hline Intercept & dimensionless & 8.75 & 0.167 & 52.3 & $<0.0001$ \\
$\begin{array}{l}\text { Log (unforested area) } \\
\begin{array}{c}\text { Outdoor swimming } \\
\text { pool size }\end{array}\end{array}$ & acres & .219 & .041 & 5.38 & $<.0001$ \\
$\begin{array}{c}\text { Log (total footprint of } \\
\text { buildings) }\end{array}$ & acres & 19.6 & 1.62 & 12.1 & $<.0001$ \\
$\begin{array}{c}\text { Log (total footprint of } \\
\text { buildings) squared }\end{array}$ & acres squared & 3.62 & .211 & 17.1 & $<.0001$ \\
\hline
\end{tabular}

Table 5. Parameter estimates, standard errors, $t$-statistics and $p$-values for multiple linear regression model of average daily summer water use at residences with public water supply, calendar year 2000, Greenwich area, Connecticut.

[Coefficient of determination $\left(\mathrm{R}^{2}\right)=0.26$ ]

\begin{tabular}{|c|c|c|c|c|c|}
\hline Variable & Units & $\begin{array}{l}\text { Parameter } \\
\text { estimate }\end{array}$ & Standard error & t-statistic & p-value \\
\hline Intercept & dimensionless & 9.23 & 0.210 & 44.0 & $<0.0001$ \\
\hline Log (unforested area) & acres & .258 & .050 & 5.20 & $<.0001$ \\
\hline $\begin{array}{l}\text { Outdoor swimming } \\
\text { pool size }\end{array}$ & acres & 22.4 & 1.99 & 11.3 & $<.0001$ \\
\hline $\begin{array}{l}\text { Log (total footprint of } \\
\text { buildings) }\end{array}$ & acres & 4.06 & .268 & 15.2 & $<.0001$ \\
\hline $\begin{array}{l}\text { Log (total footprint of } \\
\text { buildings) squared }\end{array}$ & acres squared & 1.05 & .078 & 13.6 & $<.0001$ \\
\hline
\end{tabular}

Table 6. Parameter estimates, standard errors, t-statistics and $p$-values for multiple linear regression model of average daily winter water use at residences with public water supply, calendar year 2000, Greenwich area, Connecticut.

[Coefficient of determination $\left(\mathrm{R}^{2}\right)=0.21$ ]

\begin{tabular}{llcccc}
\hline \multicolumn{1}{c}{ Variable } & \multicolumn{1}{c}{ Units } & $\begin{array}{c}\text { Parameter } \\
\text { estimate }\end{array}$ & Standard error & t-statistic & p-value \\
\hline Intercept & dimensionless & 7.73 & 0.200 & 38.7 & $<0.0001$ \\
Log (property size) & acres & .345 & .069 & 5.00 & $<.0001$ \\
Log (unforested area) & acres & .107 & .046 & 2.34 & .019 \\
$\begin{array}{c}\text { Outdoor swimming } \\
\text { pool size }\end{array}$ & acres & 12.5 & 1.73 & 7.25 & $<.0001$ \\
$\begin{array}{c}\text { Log (total footprint of } \\
\text { buildings) }\end{array}$ & acres & 2.80 & .246 & 11.4 & $<.0001$ \\
$\begin{array}{c}\text { Log (total footprint of } \\
\text { buildings) squared }\end{array}$ & acres squared & .757 & .069 & 11.0 & $<.0001$ \\
\hline
\end{tabular}






Base from Connecticut Department of Environmental Protection 1994 Digital Line Graph

Projection State Plane Feet Zone 3526

Figure 13. Estimates of average daily residential water use per square mile for small basins, Greenwich area, Connecticut. 


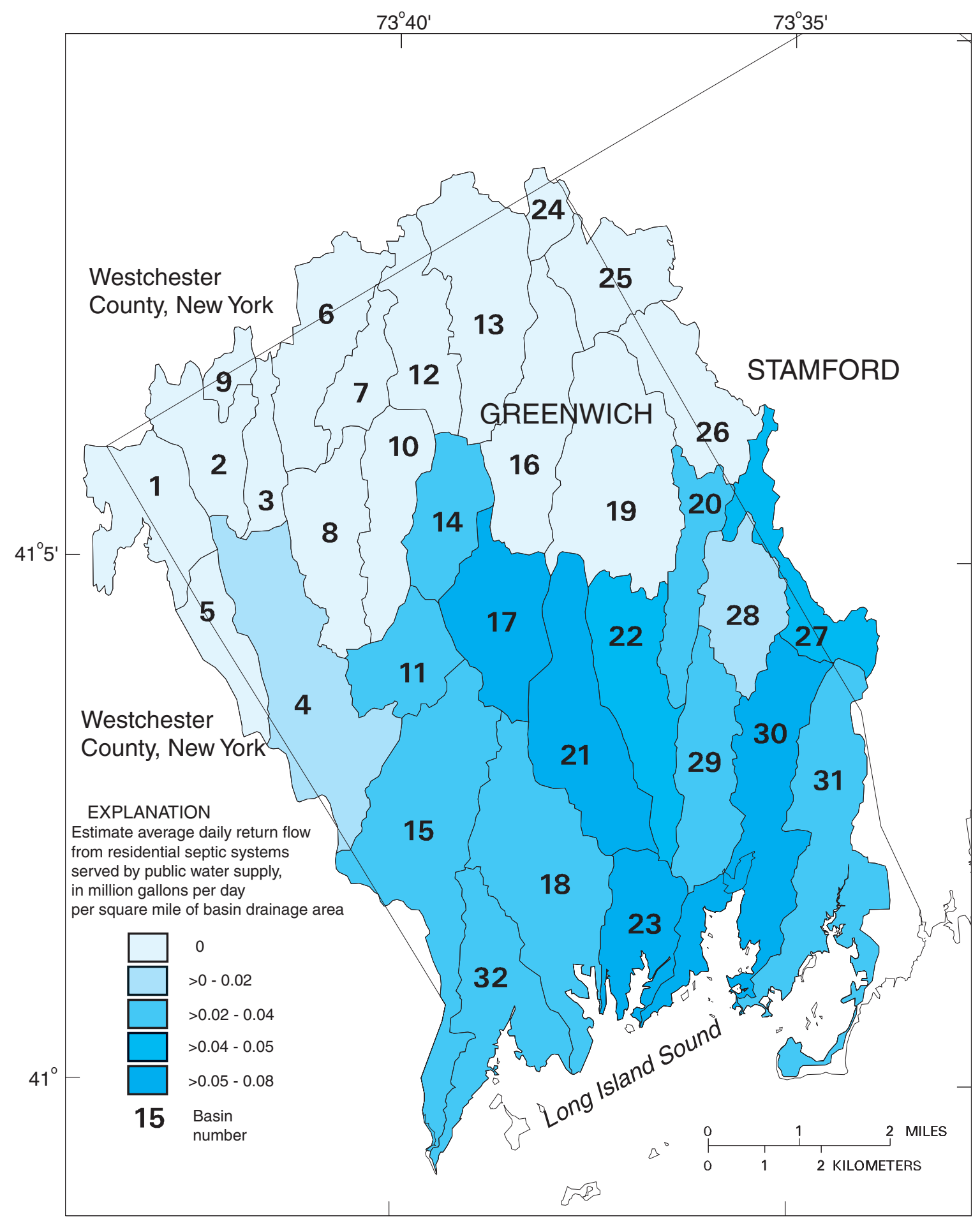

Base from Connecticut Department of Environmental Protection 1994 Digital Line Graph

Projection State Plane Feet Zone 3526

Figure 14. Estimates of average daily return flow per square mile from residential septic systems supplied by public water supply for small basins, Greenwich area, Connecticut. 


\section{Estimation of Consumptive Water Use}

Consumptive water use is the part of water withdrawn from the aquifer that is evaporated, transpired, incorporated into products or crops, consumed by humans or livestock, or otherwise removed from the immediate water environment. Estimates of consumptive water use are necessary to determine the amount of water withdrawn from the bedrock-aquifer system that is not returned, for comparison with available groundwater recharge and stream base flow. Estimates of consumptive use also are necessary to determine the amount of water imported from public water supply in Greenwich (surface-water sources) that is exfiltrated from septic systems and becomes an additional source of recharge.

The majority of consumptive water use is seasonal outdoor water use, including lawn or landscape watering, filling swimming pools, and washing vehicles. These uses are generally consumptive because water evaporates directly from surfaces or is taken up and transpired by plants to the atmosphere (U.S. Geological Survey, 1995).

Consumptive water use in Connecticut averages about 20 percent of water delivered by public water suppliers (Solley and others, 1998). In this report, consumptive use is estimated to be equal to outdoor water use. Indoor water use is probably returned to the aquifer or added as additional recharge to areas with public water supply and septic systems. Indoor water use is estimated to equal the winter water use.

Consumptive use in the study area was estimated by subtracting the winter water-use data from the average daily water use at properties that had seasonal use information. The estimated average consumptive use for 2,315 properties (with public water supply) in the Greenwich area with seasonal-use information for calendar year 2000 is 20 percent, the median is 19 , and the interquartile range is from 3 to 39 percent. This is consistent with published values for percentages of consumptive use (U.S. Geological Survey, 1995). Consumptive use estimated by the water-use models (tables 4 and $\underline{6}$, appendix 2) and aggregated by basin is higher than published values; consumptive use is estimated to average 29 percent.

\section{Water Use at Nonresidential Properties}

In addition to water use by residences, water also is withdrawn from wells for use at golf courses, country clubs, schools, churches, nurseries, and properties with commercial or institutional buildings. The determination of use for these properties is beyond the scope of this project and would require additional monitoring and willing participation from owners of these properties; however, if data were collected and analyzed, estimates of water use could be updated for each basin area shown in figure 13 . Five of the 32 basins might have a large amount ( 50 percent or more increase) of additional average daily water use due to nonresidential water uses (fig. 13); however, some of this water use (at least in the case of golf-course irrigation) may not be from ground-water sources. More information is needed to update water-use estimates for these basins.

Water use at golf courses probably represents the largest individual category of water use in Greenwich. Water generally is withdrawn from on-site ponds and wells at golf courses, and information is limited on the ratio of ground-water to surface-water supply. Golf courses can use water stored in ponds from earlier spring runoff, overland runoff of surface water from storms during the irrigation season, and by pumping of ground water. Because of these different sources, the total ground-water use and consumption would be difficult to estimate without metering wells and total system uses simultaneously.

Water use is variable among golf courses and from year to year, depending on annual or seasonal precipitation, soil type, or other localized conditions. Estimates of typical golf course irrigation rates were provided by several golf course superintendents in Greenwich (Jeffrey Scott, Tamarack Country Club; Gary Glazier, Burning Tree Country Club; Scott Niven, Stanwich Club, oral commun., 2002) and range from 60,000 to $150,000 \mathrm{gal} / \mathrm{d}$ during the growing season (May to September). This is equivalent to about 25,000 to $60,000 \mathrm{gal} / \mathrm{d}$ averaged for 1 year, assuming a 150 day irrigation season from May to September. Data from the Stanwich Club indicated that some irrigation also takes place during April and October (Aleksandra Moch, Greenwich Conservation and Inland Wetlands Department, written commun., 2002).

\section{SIMULATION OF GROUND-WATER FLOW IN THE GREENWICH AREA}

Ground-water flow in the Greenwich study area was simulated using MODFLOW-2000 (Harbaugh and others, 2000). MODFLOW-2000 is a three-dimensional, finite-difference ground-water-flow model that 
includes a nonlinear regression algorithm to find the best fit among model parameters and hydrologic observations. The purpose of the ground-water-flow model is to test hypotheses about hydrologic properties and provide a framework to estimate ground-water budgets and water availability in small basin-based zones in the Greenwich area. The calibrated model can be used to simulate hypothetical conditions involving variation in consumption of water, changes in recharge, or other changes to the hydrologic system. Two model simulations were run: (1) the first simulation was for calibration to conditions during late April 2002 using winter water-use rates, and (2) the second simulation used the calibrated model with ground-water withdrawal rates adjusted to average water-use conditions.

\section{Description of Flow Model and Model Assumptions}

The ground-water model uses a finite-difference grid with 57 rows and 46 columns (fig. 15). Individual cells in the model are 1,017 by $1,017 \mathrm{ft}$. The model has five layers of constant thickness (fig. 16). The uppermost two layers simulate the surficial aquifers that consist of thin till, thick till, glacial stratified deposits, and bedrock underlying areas with thin till (fig. 3). The top of layer 1 is the land surface. Layer 1 is $15 \mathrm{ft}$ thick, and layer 2 is $30 \mathrm{ft}$ thick. The lower three layers (each $200 \mathrm{ft}$ thick) simulate the bedrock aquifer to a depth of $645 \mathrm{ft}$ below land surface. The depth was selected because it is greater than the average depth of wells in Greenwich. The average depth of 400 wells compiled from well completion reports was about $450 \mathrm{ft}$. Model layers are assumed to be confined, including layer 1 , due to numerical instability in the model with thin uppermost layers. The model is a steady-state groundwater-flow model that is calibrated to a stable period (April 2002) when recharge and discharge were in balance and no major changes were taking place in ground-water storage. Steady-state ground-water-flow models are used to simulate long-term average conditions, or stable periods of increased or reduced recharge. The ground-water-flow model of the Greenwich area was calibrated to 34 ground-water levels measured during April 16-20, 2002; water levels from 402 well-completion reports (fig. 17); and streamflow measurements at 8 sites (table 2). Water levels that were measured during April 2002 were assumed to represent average conditions because water levels in wells from the USGS statewide-monitoring network with monthly measurements (table 7; fig. 6) were at average (period of record) conditions during this time period. Normally during April, water levels in wells would be at above-average conditions; however, the spring of 2002 was very dry, and water levels in wells in the USGS statewide-monitoring network in Fairfield County were close to average conditions. Groundwater levels and streamflow in Greenwich during April 16-25 were generally stable, with little change (fig. 18).

The model also was calibrated to streamflow measurements from eight locations (table 1) in the Greenwich area on April 24-25, 2002. Streamflow during this time period was stable and represents base flow (fig. 18). These observations included seven measurements of discharge, and one determination of discharge from a rating curve at a continuous streamflow-gaging station number 01211110 (fig. 2).

The bedrock aquifer is simulated in this model as homogeneous and isotropic. This model is designed primarily to understand the water budget and should not be used for studies that require detailed flow-path analysis. In reality, the frequency and spatial orientation of fractures in the bedrock are likely to affect local ground-water-flow directions and possibly groundwater budgets. A similar approach modeling the water budget and hydraulic properties of fractured crystalline bedrock aquifers as an equivalent porous medium was used by Tiedeman and others (1997) and Wolcott and Snow (1995).

The steady-state ground-water-flow model was calibrated to observations of ground-water levels and streamflow. The calibration process is a nonlinear regression to provide optimal estimates of parameters based on the best fit to measured (or observed) values of hydraulic head and streamflow. Model parameters were estimated using a nonlinear-regression method developed by Cooley and Naff (1990) and applied to MODFLOW 2000 by Hill and others (2000). 


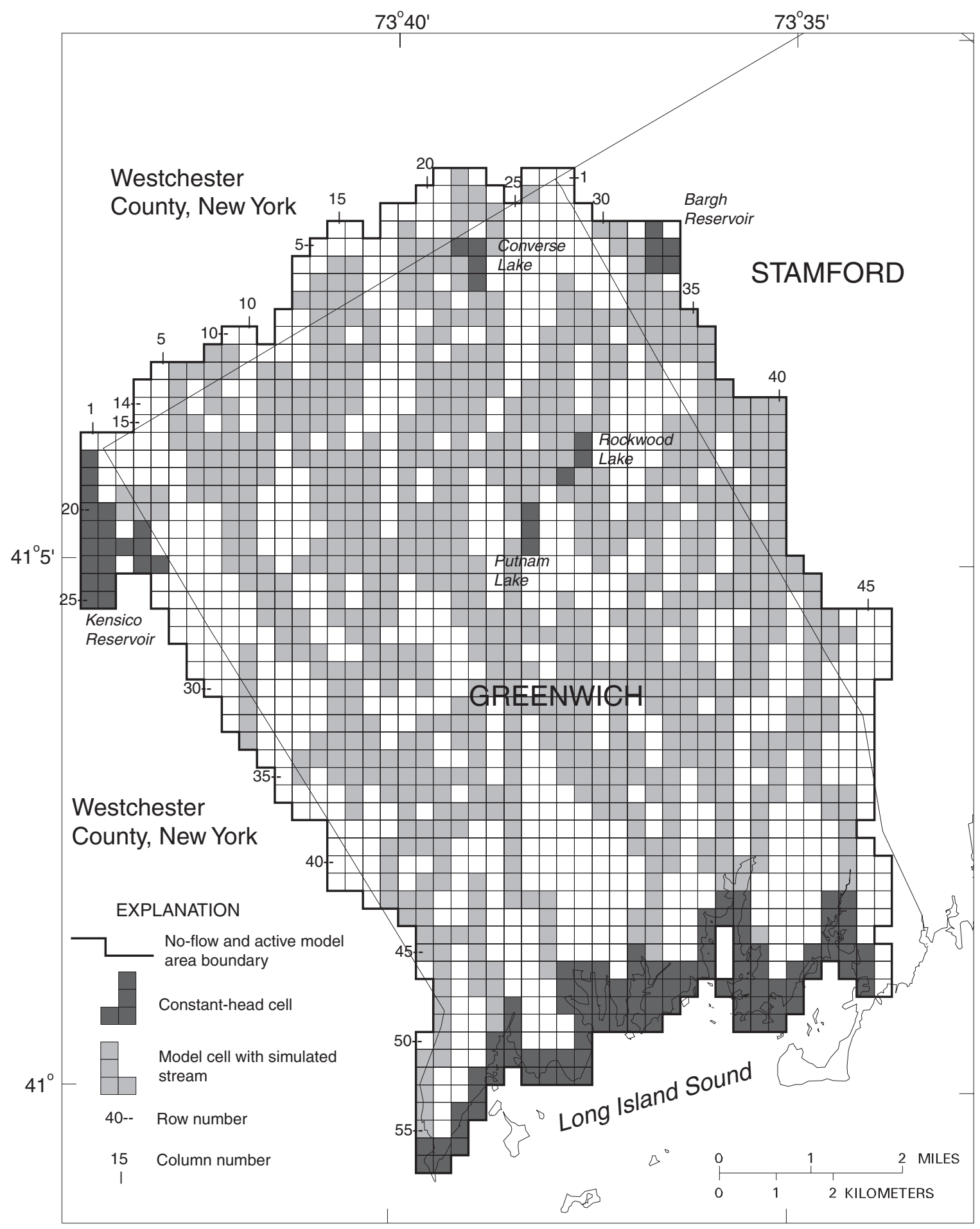

Base from Connecticut Department of Environmental Protection 1994

Digital Line Graph

Projection State Plane Feet Zone 3526

Figure 15. Extent of finite-difference ground-water-flow model grid, Greenwich area, Connecticut. 

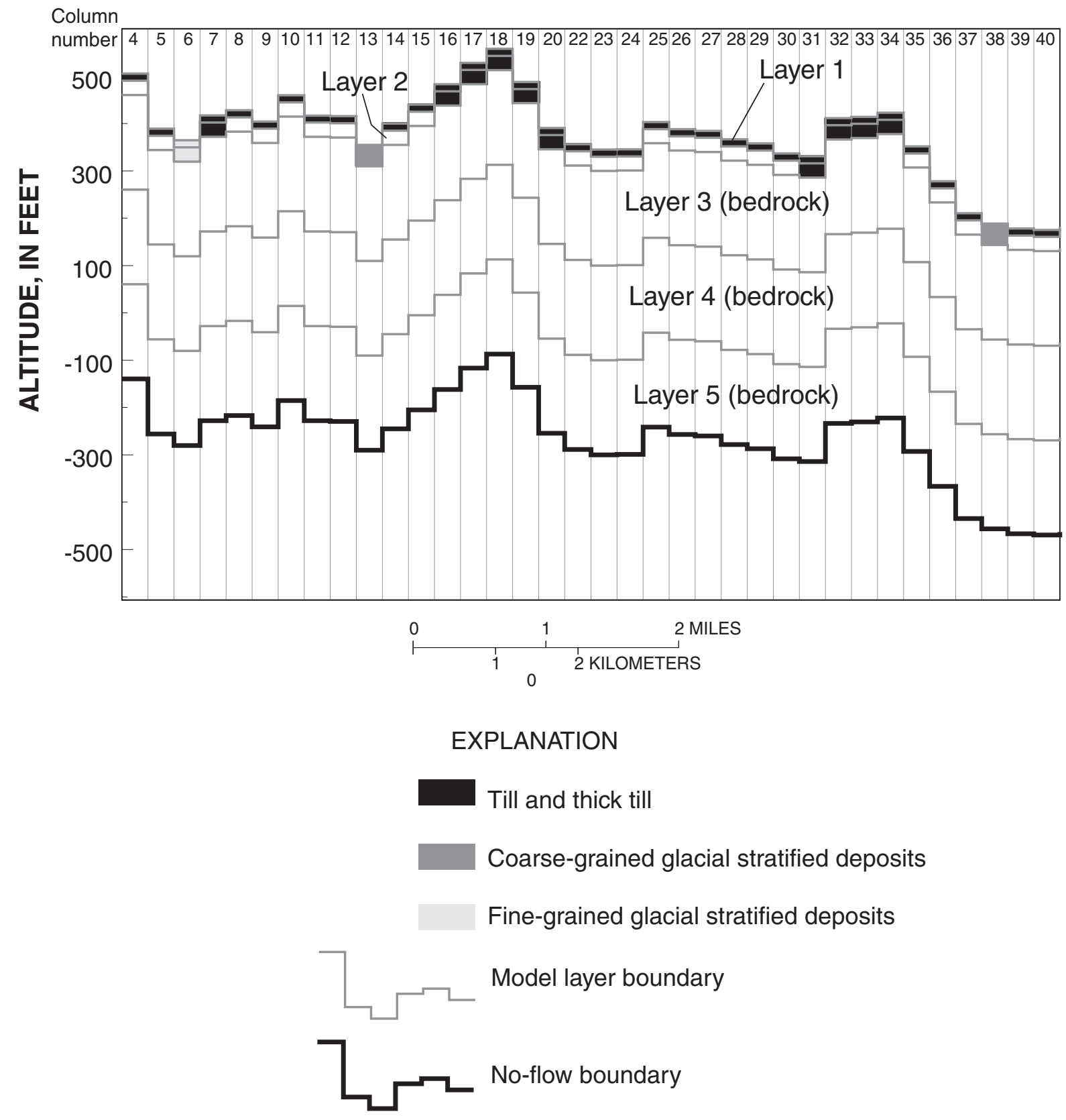

Figure 16. Cross section through row 14 (see fig. 15), in the finite-difference ground-water-flow model, Greenwich area, Connecticut. 


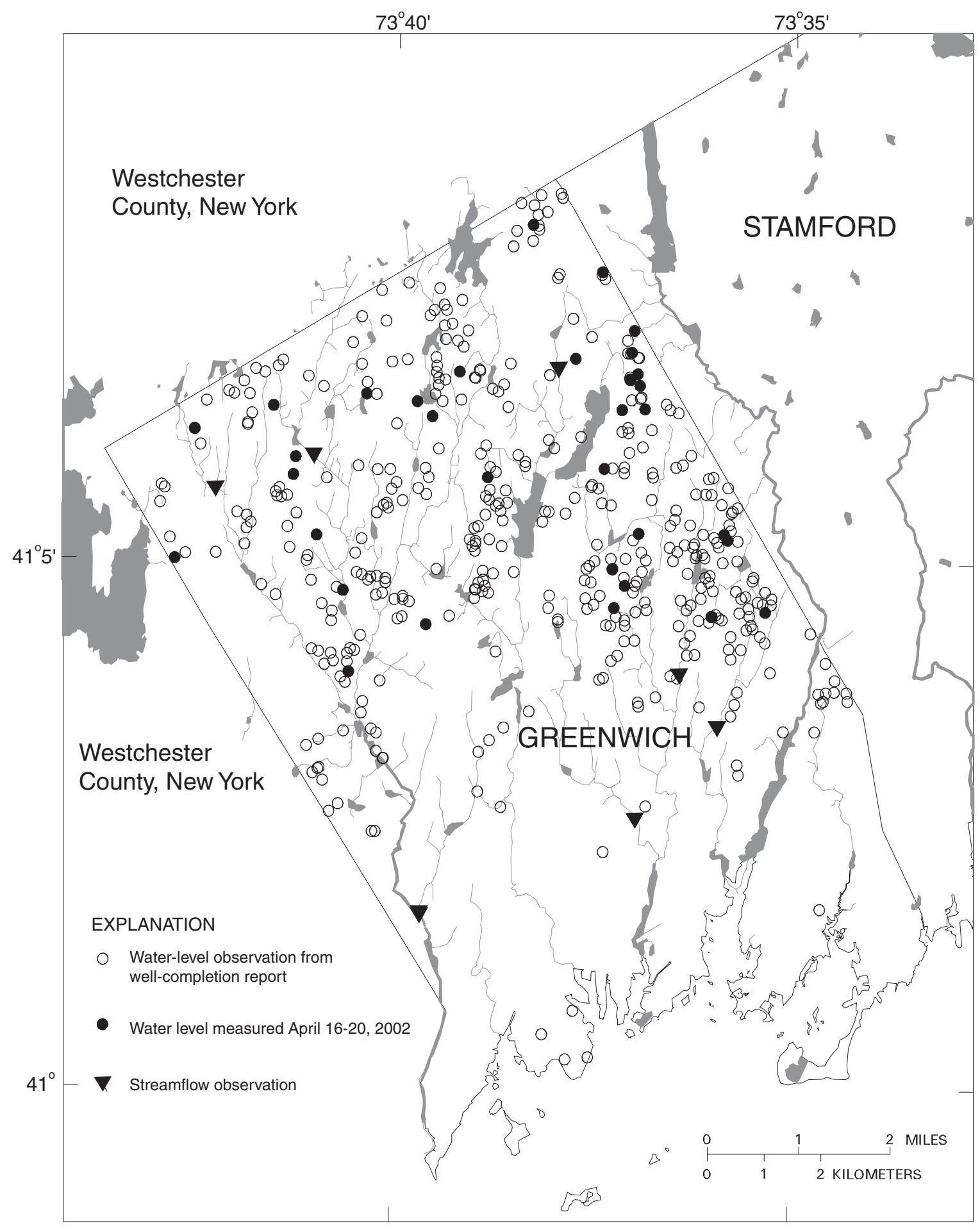

Base from Connecticut Department of Environmental Protection 1994 Digital Line Graph

Projection State Plane Feet Zone 3526

Figure 17. Location of observations for ground-water levels and streamflow, Greenwich area, Connecticut. 


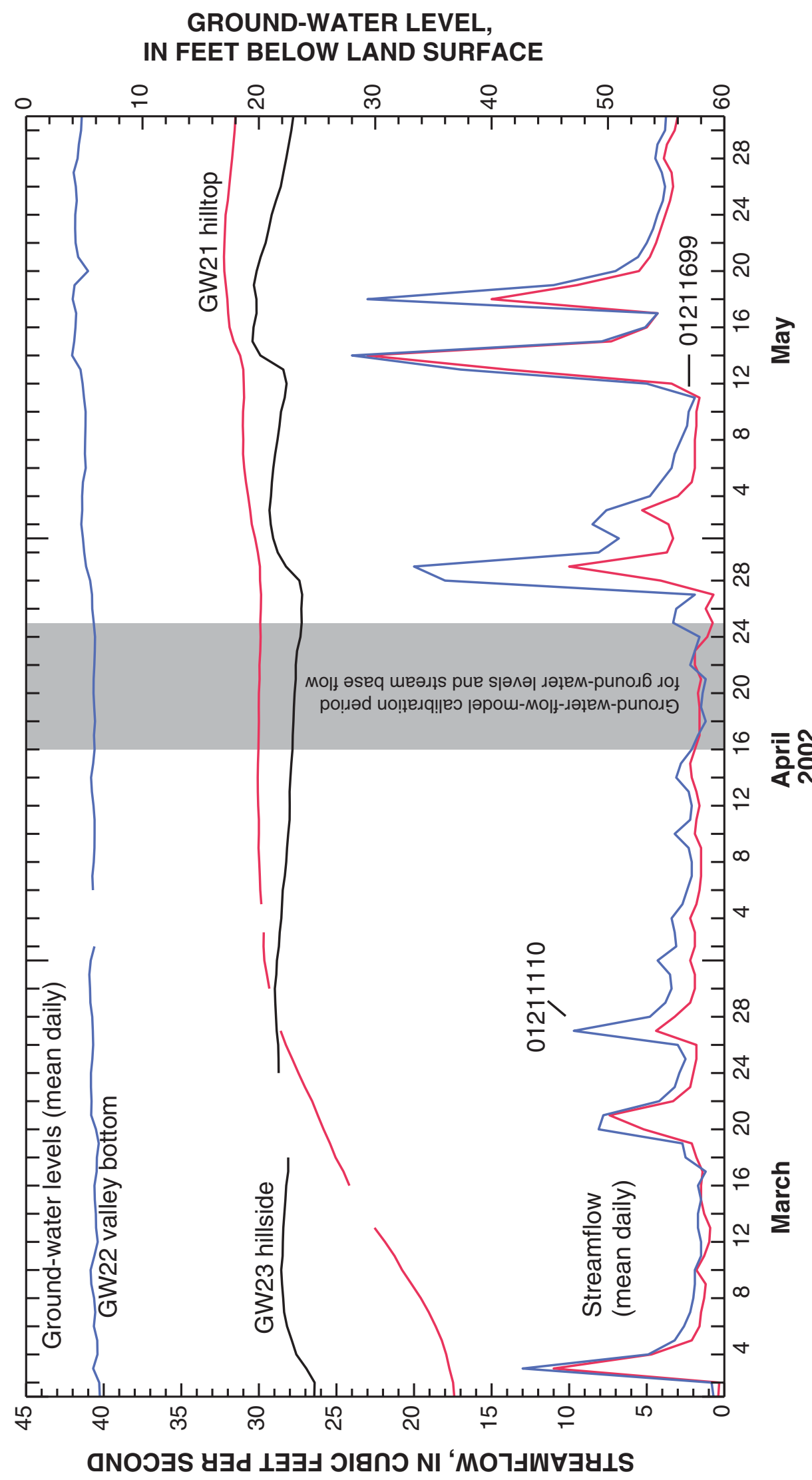

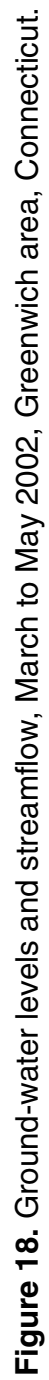


Table 7. Water levels in April 2002 and average water levels at selected U.S.Geological Survey network wells in Fairfield County, Connecticut.

[Water levels in feet below land surface; USGS, U.S. Geological Survey]

\begin{tabular}{llcccc}
\hline $\begin{array}{c}\text { USGS local well } \\
\text { identifier and } \\
\text { station number } \\
\text { (see fig. 6) }\end{array}$ & Town & $\begin{array}{c}\text { April 2002 } \\
\text { water level }\end{array}$ & $\begin{array}{c}\text { Average } \\
\text { water } \\
\text { level }\end{array}$ & $\begin{array}{c}\text { Period of } \\
\text { record used }\end{array}$ & Aquifer \\
\hline $\begin{array}{l}\text { FF23 } \\
411256073153101\end{array}$ & Fairfield & 8.13 & 7.89 & $1966-2002$ & Glacial stratified deposits \\
$\begin{array}{l}\text { FF30 } \\
411124073172201\end{array}$ & Fairfield & 4.87 & 4.94 & $1993-2002$ & Crystalline bedrock \\
$\begin{array}{l}\text { FF31 } \\
411118073175801\end{array}$ & Fairfield & 7.04 & 8.47 & $1993-2002$ & Crystalline bedrock \\
$\begin{array}{l}\text { FF32 } \\
411030073181301\end{array}$ & Fairfield & 6.31 & 7.71 & $1993-2002$ & Crystalline bedrock \\
$\begin{array}{l}\text { FF33 } \\
411058073182001\end{array}$ & Fairfield & 5.18 & 5.30 & $1993-2002$ & Till \\
$\begin{array}{l}\text { BD8 } \\
413007073250501\end{array}$ & Brookfield & 32.37 & 30.56 & $1966-2002$ & Glacial stratified deposits \\
\hline
\end{tabular}

\section{Boundary Conditions}

The lateral model boundaries are based mostly on physical boundaries of the Greenwich area, including basin boundaries and streams (ig. 15). Basin boundaries on the perimeter of the model are treated as no-flow boundaries, and streams near the model boundaries are treated as head-dependent boundaries simulated with the MODFLOW stream package (Prudic, 1989). Other model boundaries include Long Island Sound on the southern side of the model, simulated as a constant-head boundary with altitude zero; the Byram River (fig. 2) in the southwestern part of the model, simulated as a head-dependent boundary; and the Mianus River on the eastern side of the model (head-dependent boundary) (fig. 15). To limit the size of the active model, three areas of the model were terminated across basin boundaries at a narrow point. These areas include the northeastern corner of the model area, and the Blind Brook Basin (fig. 2) in Westchester County, where streamflow leaves the model. The model also is terminated across a narrow point in the Byram River Basin (fig. 2) where streamflow enters the model. The large reservoirs, including the Kensico Reservoir, part of the Bargh Reservoir, Putnam Lake, Rockwood Lake, and Converse Lake (figs. 2 and 14), were simulated as constant head boundaries, because of their large size and typically large quantities of water in storage at all times other than extreme drought periods.

The lower model boundary is a no-flow boundary that is $645 \mathrm{ft}$ below land surface. The upper boundary of the model is the land surface. Recharge is applied to layer 1 in the model and is considered a specified-flux boundary.

\section{Ground-Water Recharge}

Ground-water recharge to areas with glacial till was estimated using optimal values based on nonlinear regression modeling in MODFLOW. Ground-water recharge to glacial stratified deposits was held constant at previously estimated values (table 8). Recharge rates in the model are effective recharge rates and account for the effects of ground-water evapotranspiration. A recharge parameter was defined in the model using a zone array (fig. 19A) corresponding to surficial geology, and a multiplication array corresponding to the percent pervious area in the model cell. The recharge parameter multiplied by the percentage of pervious area in each model cell determined the recharge value for the model input. This was done because peak streamflows (normalized to drainage area) in urbanized basins are higher than in basins with less urban development (fig. 20). The increased overland runoff limits the amount of water available for recharge, ultimately reducing the base flow of streams. These recharge estimates are conservative, because not all impervious areas drain directly into watercourses. Water from rooftops and driveways may infiltrate onto lawns or other unpaved areas, and stormwater drainage from some areas may infiltrate to the water table if the stormwater is discharged to retention basins or is allowed to flow onto pervious areas. 


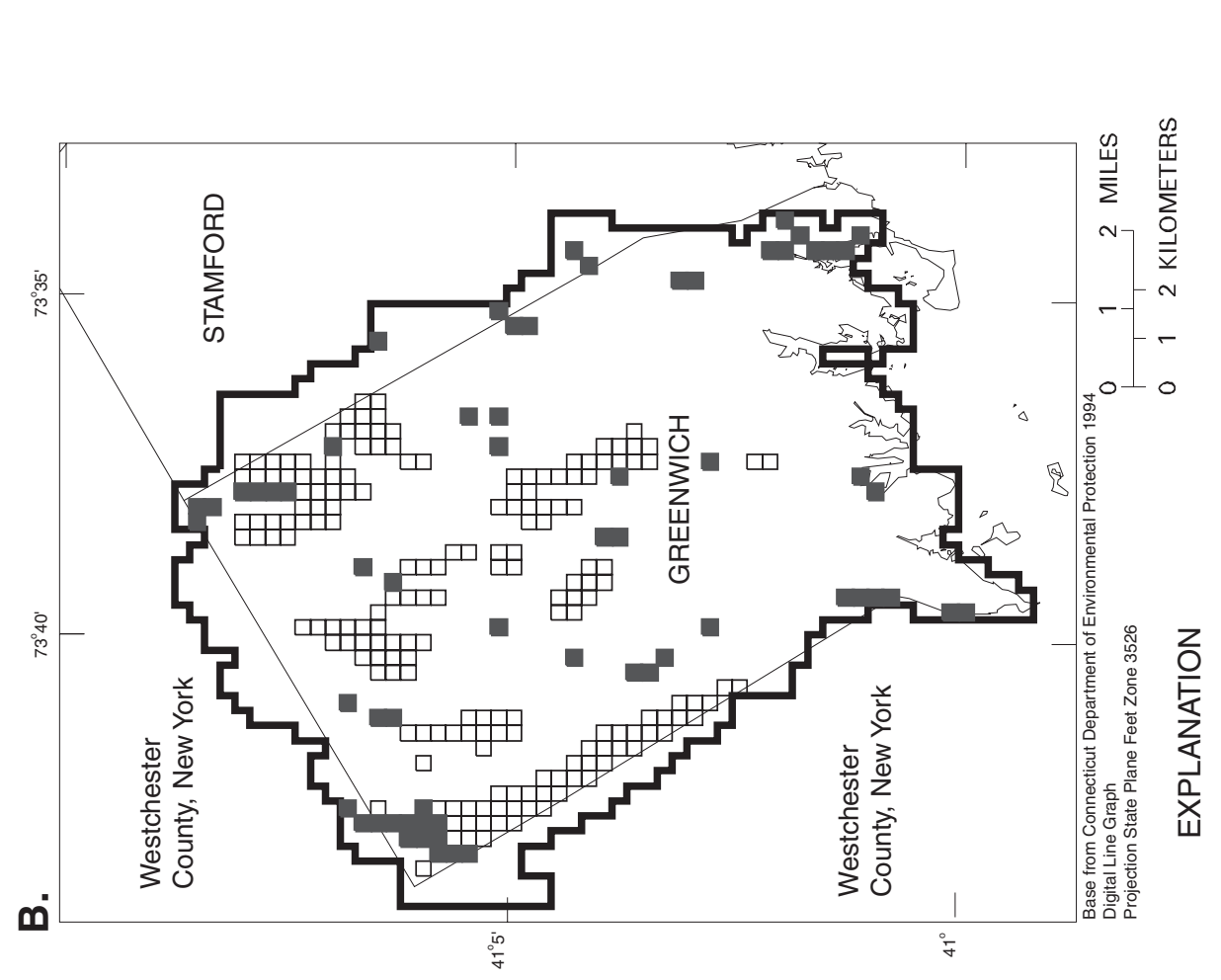

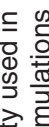

خ্

을

음은

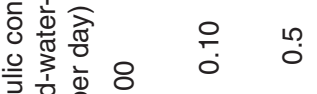

츤

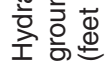

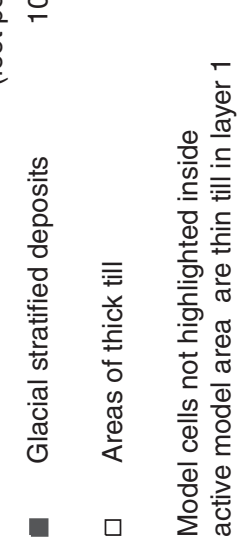

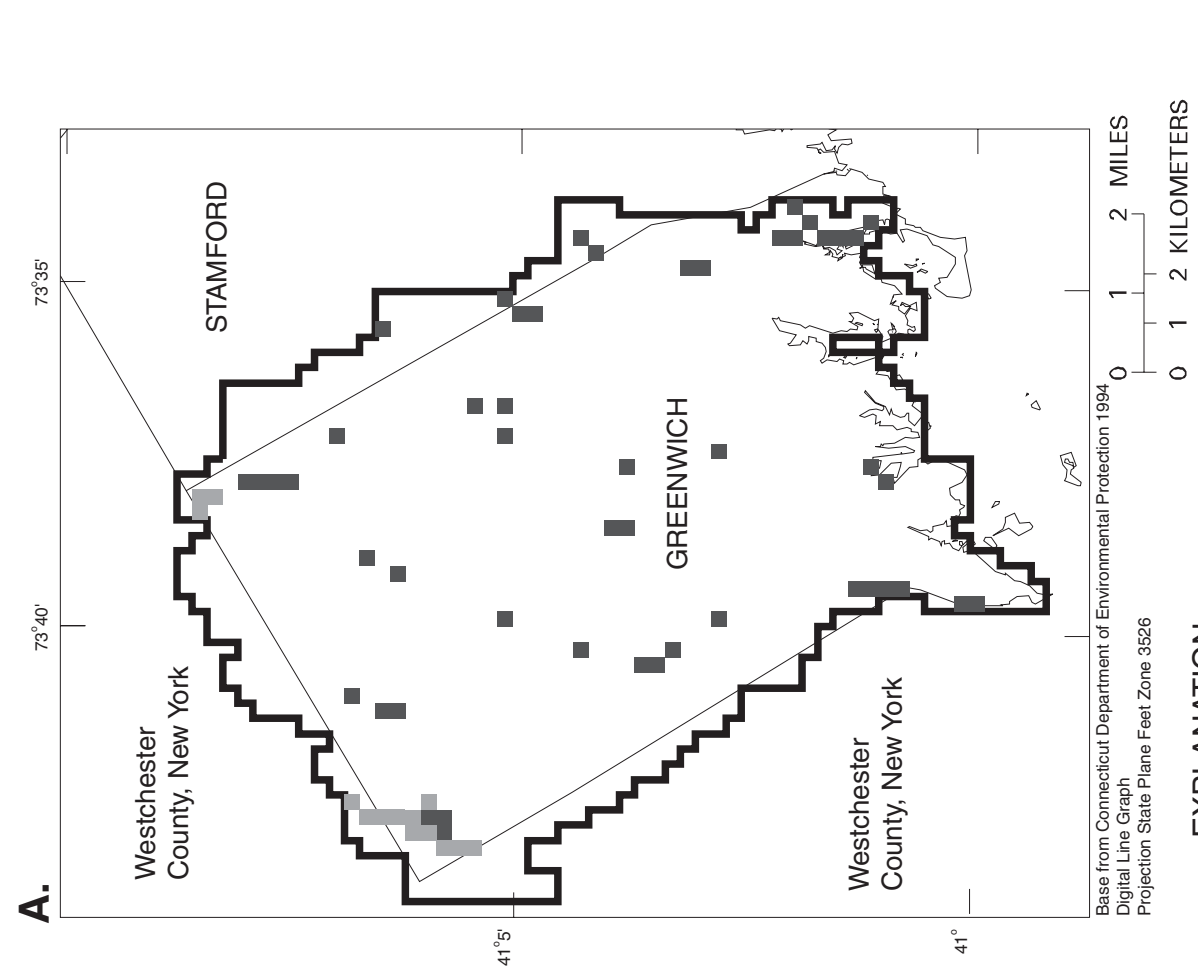

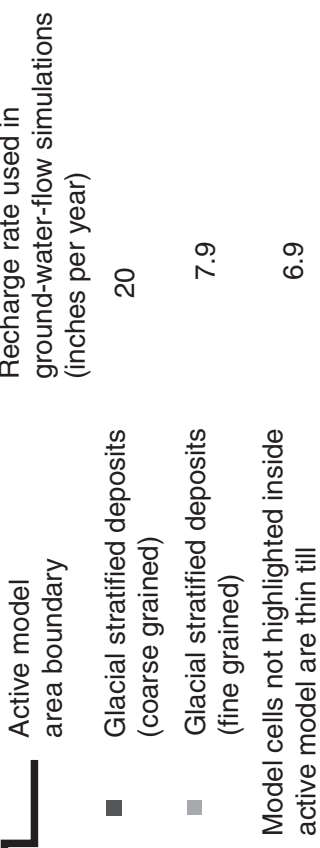


Table 8. Recharge estimates from historical values and nonlinear regression for April 2002 calibration.

$[*$, value presented in model calibration section of report]

\begin{tabular}{|c|c|c|}
\hline Recharge parameter & Method & $\begin{array}{c}\text { Recharge } \\
\text { (inches per } \\
\text { year) }\end{array}$ \\
\hline Till & $\begin{array}{l}\text { Nonlinear } \\
\text { regression }\end{array}$ & $*$ \\
\hline $\begin{array}{l}\text { Glacial stratified deposits, } \\
\text { coarse grained }\end{array}$ & $\begin{array}{l}\text { Historical } \\
\text { values }\end{array}$ & ${ }^{1} 20$ \\
\hline $\begin{array}{l}\text { Glacial stratified deposits, } \\
\text { fine grained }\end{array}$ & ${ }^{2}$ Estimated & 7.9 \\
\hline
\end{tabular}

${ }^{1}$ Value from Mazzaferro, 1986.

${ }^{2}$ The area of fine-grained glacial stratified deposits represents a very small area in the ground-water flow model; a recharge rate similar to those for glacial till was used because of the low permeability of these deposits.

The percentage of impervious area in each model cell was estimated by two methods. For model cells completely within the town of Greenwich, impervious areas were estimated from 1997 Greenwich GIS layers as the sum of paved roadway areas, building areas, and driveway and sidewalk areas. In Greenwich GIS layers, driveways and sidewalk areas are linear features and have no area associated with them. To estimate the areas of these features, the length was divided by 2 and multiplied by the estimated width (driveways-13 ft; sidewalks-5 ft).

For model cells in areas outside Greenwich, impervious areas were estimated from a grid of land use/land cover based on 1995 Landsat thematic mapper images interpreted by Civco and others (1998). A regression model (fig. 21) was used to relate landuse/land-cover characteristics from Civco and others (1998) (table 9) to the calculated impervious areas in each of 120 randomly selected model cells in the Greenwich part of the model area. Predictions based on the regression model were applied to the model area outside Greenwich. Significant variables in the regression at the 95-percent confidence level included the urban categories "Commercial/Industrial/Paved," "Residential and Commercial," and "Turf and Tree Complex." Other urban variables, including "Turf and Grass" and "Rural Residential" were not found to be significant predictors of impervious area. Model residuals were determined to be reasonably normally distributed (fig. 21).

Table 9. Parameter estimates, standard errors, t-statistics and p-values for multiple linear regression model of percentage of impervious area for randomly selected cells of the finite-difference ground-water-flow model, Greenwich area, Connecticut.

[Coefficient of determination $\left(\mathrm{R}^{2}\right)=0.87$ ]

\begin{tabular}{llccrr}
\hline \multicolumn{1}{c}{ Variable } & \multicolumn{1}{c}{ Units } & $\begin{array}{c}\text { Parameter } \\
\text { estimate }\end{array}$ & $\begin{array}{c}\text { Standard } \\
\text { error }\end{array}$ & t-statistic & p-value \\
\hline Intercept & Dimensionless & 2.0814 & 0.5464 & 3.8094 & 0.0002 \\
$\begin{array}{c}\text { Commercial/ } \\
\text { industrial/paved }\end{array}$ & $\begin{array}{c}\text { Percentage of model } \\
\text { cell area }\end{array}$ & 0.6631 & 0.0475 & 13.9696 & $<.0001$ \\
$\begin{array}{c}\text { Residential and } \\
\text { commercial }\end{array}$ & $\begin{array}{c}\text { Percentage of model } \\
\text { cell area }\end{array}$ & 0.3331 & 0.0167 & 19.9993 & $<.0001$ \\
$\begin{array}{c}\text { Turf and tree } \\
\text { complex }\end{array}$ & $\begin{array}{c}\text { Percentage of model } \\
\text { cell area }\end{array}$ & 0.1232 & 0.0166 & 7.4342 & $<.0001$ \\
\hline
\end{tabular}




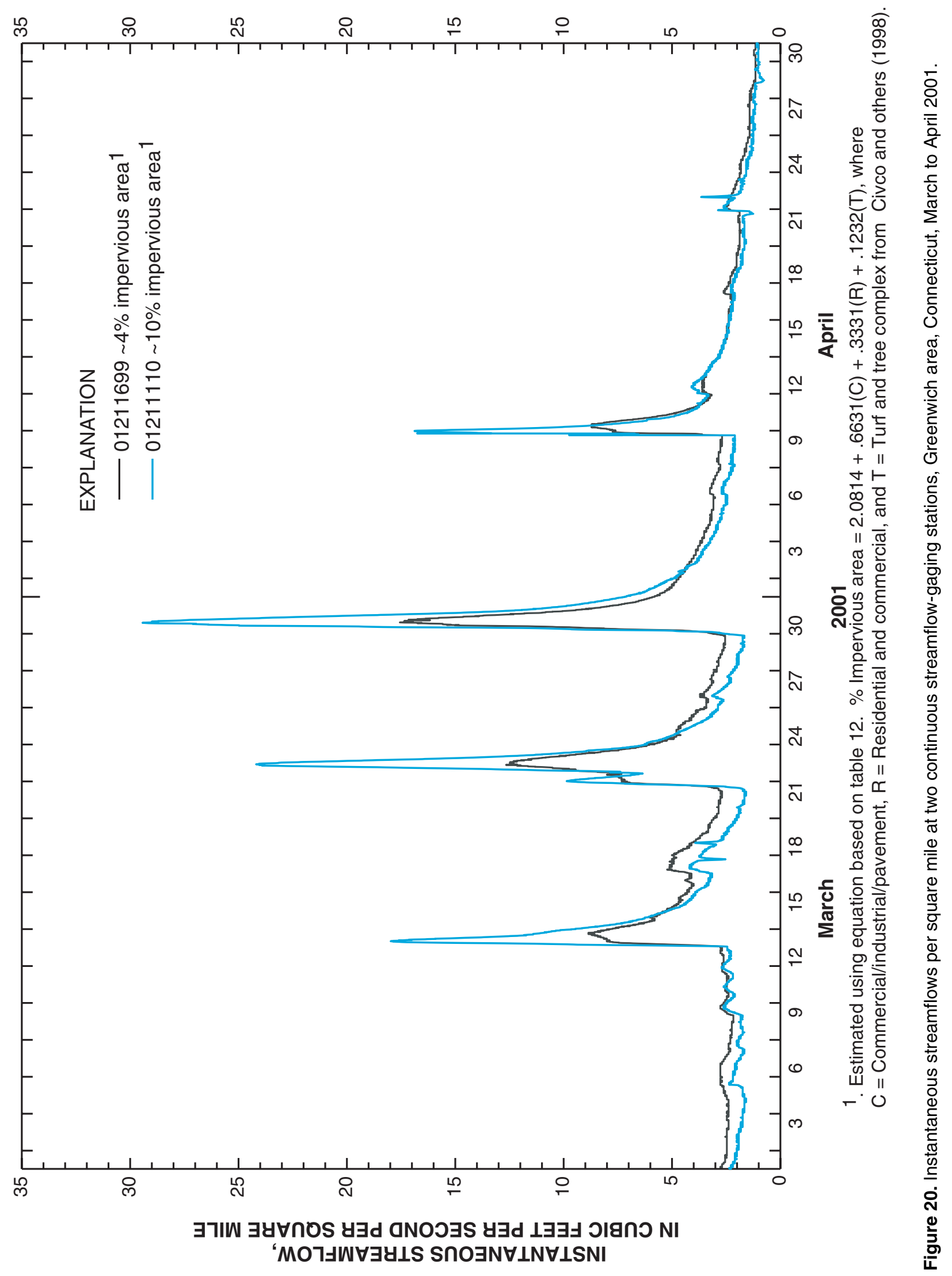




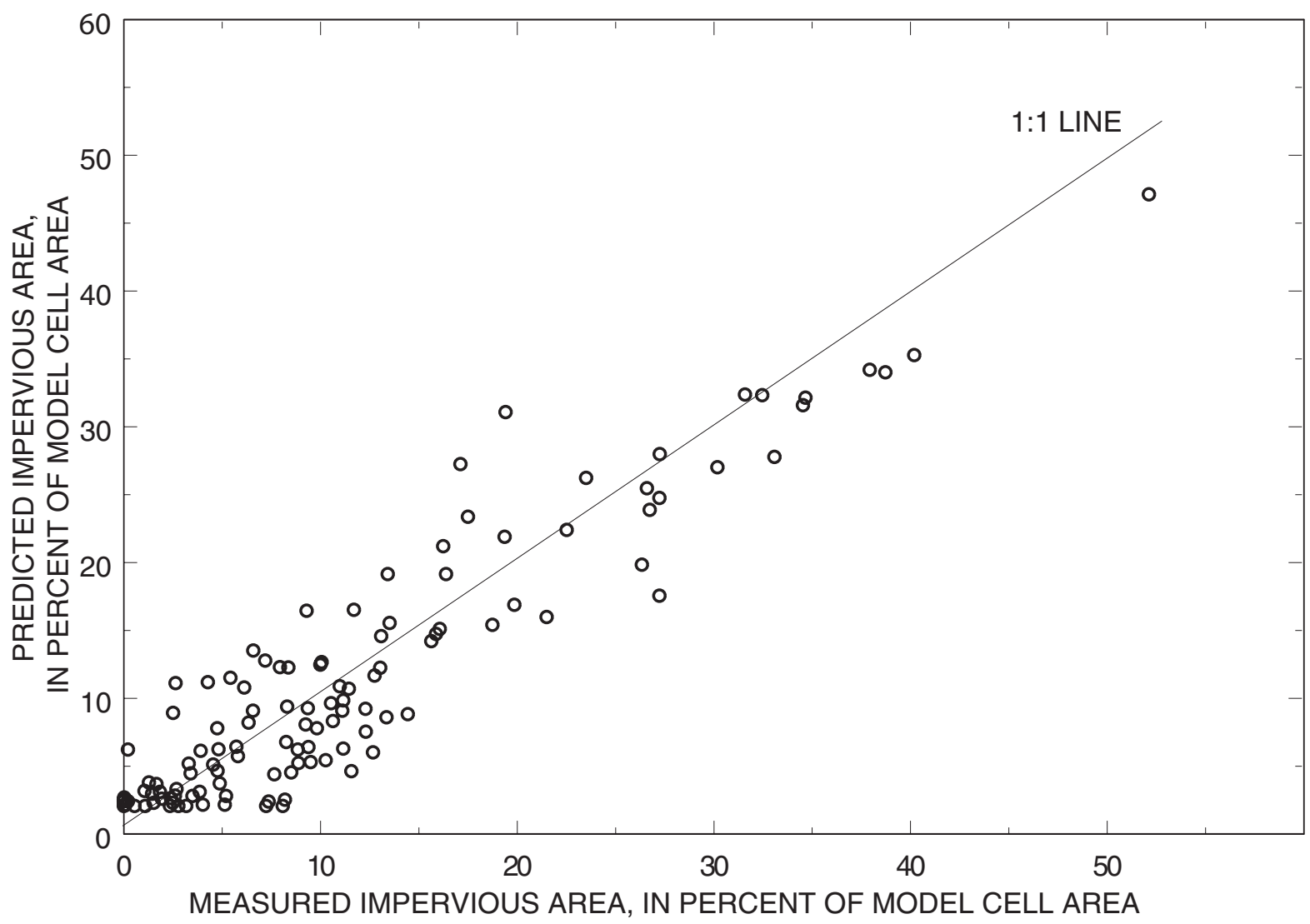

Figure 21. Measured and predicted impervious areas for a random sample of model cells, Greenwich area, Connecticut.

\section{Aquifer Properties}

Hydraulic conductivity of aquifer materials either was assigned based on information from previous investigations or was estimated using nonlinear regression. Hydraulic conductivity of the crystalline bedrock was estimated by nonlinear regression in MODFLOW 2000. Hydraulic conductivity of glacial stratified deposits, thin till, and thick till were based on values summarized in table 10. Values from table 10 were applied using zone arrays (fig. 19) for layers 1 and 2. Layers 3 to 5 were completely in bedrock, and a zone array was not used.

Table 10. Simulated values of hydraulic conductivity in finite-difference ground-water-flow model, Greenwich area, Connecticut.

[*, value presented in model calibration section of report]

\begin{tabular}{llcc}
\hline \multicolumn{1}{c}{ Aquifer material } & \multicolumn{1}{c}{ Method } & $\begin{array}{c}\text { Median values from } \\
\text { Hydraulic conductivity } \\
\text { (feet per day) }\end{array}$ & $\begin{array}{c}\text { Medical summary by } \\
\text { historical } \\
\text { Melvin and others (1992) } \\
\text { (feet per day) }\end{array}$ \\
\hline Thin till & Historical values & 0.5 & $0.6-2.7$ \\
Thick till (drumlin till) & Historical values & .10 & .06 \\
$\begin{array}{l}\text { Glacial stratified deposits } \\
\text { (combined coarse and fine grained) }\end{array}$ & Historical values & 100 & 170 \\
Crystalline bedrock & Nonlinear regression & $*$ & (coarse grained) \\
\hline
\end{tabular}




\section{Internal Sources and Sinks of Water}

Ground water is added (source) or removed (sink) from the modeled area through streams, reservoirs, wells, and septic systems. Simulation of these sources and sinks is described below.

\section{Streamflow}

Streams were simulated using the stream package created for MODFLOW by Prudic (1989). The stream package is an accounting program that tracks the flow in streams that interact with ground water. The package allows for diversions of water among basins and provides output for comparisons with streamflow measurements made for model calibration.

The active model area (fig. 15) contains 427 stream segments and 1,375 reaches. Streamflows are estimated for every cell in the ground-water-flow model that contains a stream reach and are accumulated in a downstream direction. Discharge between each stream reach and the adjacent aquifer is calculated using Darcy's Law and the equation from Prudic (1989):

$$
Q=C_{S T R}\left(H_{S}-H_{a}\right)
$$

where:

$Q \quad$ is leakage to or from the aquifer through the streambed

$H_{s}$ is head in the stream

$H_{a}$ is head in the aquifer

$C_{S T R}$ is conductance of the streambed, defined as $K L W / M$, where $K$ is the hydraulic conductivity of the streambed, $L$ is the length of the reach, $W$ is the width of the stream in the reach, and $M$ is the streambed thickness.

Streambed hydraulic conductivity was assumed to be $1 \mathrm{ft} / \mathrm{d}$, and streambed thickness was assumed to be $1 \mathrm{ft}$. Streambed altitude was determined for each reach from a grid of 3,652 points regularly spaced every 225 $\mathrm{ft}$ along all streams. The initial altitude of each point was determined using a digital elevation model. The values were then adjusted by visually inspecting each in comparison to USGS 10-ft contour quadrangle maps. Stream stage was assumed to be $2 \mathrm{ft}$ higher than streambed altitude.

Streamflows predicted by the stream package downstream from the large reservoirs (Putnam and
Rockwood Lakes) may be over- or underestimated because of the lack of information on daily diversions, withdrawals, and releases. Simulated streamflows for each zone represent the amount of water discharged from the ground-water system to the stream. Withdrawals from and diversions to these reservoirs will, in reality, affect the actual streamflow. Streamflows estimated for streams that are boundaries (fig. 15) in the model (that is, the mainstems of Mianus and Byram Rivers, fig. 2) do not include ground-water discharge or tributaries that may flow into these rivers from outside the model area.

\section{Reservoirs}

Reservoirs (Kensico, Converse Lake, Rockwood Lake, Putnam Lake, Bargh (figs. 2 and 14) were simulated as constant heads. This allows for an unlimited amount of water to enter the aquifer if heads in the aquifer are below those of the constant head. Another approach to simulating the reservoirs would be to use a general head boundary. Constant head boundaries were chosen for this simulation for the following reasons: (1) the discharge from reservoirs to the ground-water system was small, indicating that reservoirs were not a major source of recharge; (2) the hydraulic conductivity of the till deposits is small, and of the same order of magnitude or lower than reservoir bottom sediments, therefore it is likely that the flow of water to or from reservoirs is primarily controlled by the properties of the underlying aquifers; and (3) large quantities of water are stored at all times of year in these reservoirs.

\section{Ground-Water Withdrawals and Return Flow from Septic Systems}

In the calibration model simulation, groundwater withdrawals from residential land-use areas were summed for each model cell based on the water-use multiple-linear regression models described previously. The ground-water model was calibrated using streamflow and water-level data collected during midto late April 2002; therefore, ground-water withdrawals were assumed to represent nongrowing season conditions. Ground-water was withdrawn from layer 3 of the model, which represents the top of bedrock. Several recent studies have shown that a large percentage of the discharge from wells in fractured rock comes from shallow fractures near the surface of the bedrock (Mullaney and others, 1999; Wolcott and Snow, 1995). 
Return flow from septic systems was simulated as recharging wells summed for each model cell and was assumed to be equivalent to indoor water use; therefore, winter water-use rates were used. Return flow from septic systems includes water returned in areas with private wells and in areas with public water supply and septic systems. Water from septic systems was returned to layer 1 in the model. It should be noted that based on the assumptions described above, net ground-water consumption (in areas with wells and septic systems) is considered to be negligible during April 2002.

In the second simulation, in which average pumping conditions were simulated, the regression model estimates for average daily water use were applied to model cells; however, return flow was again assumed to be similar to winter water-use rates.

\section{Model Calibration}

The calibration process is a nonlinear regression to provide optimal estimates of parameters based on the best fit to measured (or observed) values of hydraulic head and streamflow. Two parameters in the model were estimated in this way-horizontal hydraulic conductivity of the bedrock aquifer and recharge to till deposits (table 11). These two parameters are important because the majority of ground-water flow takes place in the bedrock aquifer, and the majority of recharge takes place through till deposits. Other parameters that were not estimated using the nonlinear-regression method were based on values from previous investigations in Connecticut.

Table 11. Parameter estimates of hydraulic conductivity and recharge from nonlinear regression, finite-difference groundwater flow model, Greenwich area Connecticut.

\begin{tabular}{lcc}
\hline Estimated parameter & Value & Unit \\
\hline $\begin{array}{l}\text { Horizontal hydraulic } \\
\text { conductivity crystalline } \\
\text { bedrock }\end{array}$ & 0.05 & Feet per day \\
Recharge to till deposits & 6.9 & Inches per year \\
\hline
\end{tabular}

The ground-water-flow model of the Greenwich area was calibrated to 34 ground-water levels measured during April 16-20, 2002, water levels from 402 wellcompletion reports for wells (fig. 17) and streamflow measurements at 8 sites. Water levels from wellcompletion reports represent a wide range of waterlevel conditions. It is assumed that this range of conditions represents long-term average annual conditions.
Data from water-level measurements and well-completion reports are subject to errors, including inaccuracy in determining location and land-surface elevation. Data from wells measured during April 2002 were given a larger weighting in the calibration process.

The weighting process for water level and streamflow measurements was accomplished as follows. Data that have a higher degree of accuracy are given a larger weight. The weights reflect the possible measurement error in the data and are equal to the inverse of the variance of the measurement. The variance in the measurements for both streamflow and water-level measurements was determined subjectively, based on an assessment of, in the case of water level measurements, the accuracy of the location and the land-surface elevation. The measurement error was assumed to be half the contour interval of the topographic map provided by the town of Greenwich ( $2 \mathrm{ft})$. This translates to a variance in water level measurements for wells measured in April 2002 that was estimated to be $0.37 \mathrm{ft}^{2}$ at the 90 -percent confidence level. Measurements obtained from well-completion reports were assumed to be less accurate because the wells were not located in the field. The weight of these measurements was assumed to be one, which translates to a measurement error of $1.65 \mathrm{ft}$ at the 90 -percent confidence interval. The methods of estimating model observation weights are described by Hill (1998).

The weighting of the streamflow measurements in the calibration process was dependent on the assignment of whether the measurement was determined to be good, fair, or poor based on width of the river and stream cross-section characteristics. This weighting process for observations of streamflow loss or gain is described by Hill (1998).

A plot of the weighted simulated equivalents and weighted observations is shown in figure 21. This plot contains information on the fit among the observations and values predicted by the calibrated ground-water model. The model residuals appear to be normally distributed (fig. 22), but there are some wells with water-level observations in the ground-water-flow model where predicted water levels are much higher or lower than observed. There does not appear to be a geographic bias in water-level residuals. The average weighted error in the water-level measurements was $1.9 \mathrm{ft}$ (table 12). There was generally good agreement among streamflow observations (weighted and unweighted) and predictions (table 13, fig. 22). 
Table12. Summary of error statistics and comparison of observed and simulated ground-water levels, Greenwich area, Connecticut, April 16-20, 2002.

\begin{tabular}{ll}
\multicolumn{1}{c}{ Statistic } & \multicolumn{1}{c}{ Value } \\
& \\
\hline $\begin{array}{l}\text { Sum of squared weighted errors } \\
\text { Average weighted error } \\
\quad \text { (ground-water level measurements) } \\
\text { Average unweighted error } \\
\quad \text { (ground-water level measurements) }\end{array}$ & $1.90 \mathrm{feet}$ \\
\hline
\end{tabular}

Table 13. Observed and simulated streamflows, Greenwich area, Connecticut, April 24-25, 2002.

[USGS, U.S. Geological Survey; $\mathrm{ft}^{3} / \mathrm{s}$, cubic feet per second]

\begin{tabular}{|c|c|c|c|}
\hline $\begin{array}{c}\text { USGS station identification } \\
\text { number } \\
(\underline{\text { table 1 }}, \underline{\text { fig. } 2)})\end{array}$ & $\begin{array}{l}\text { Observed } \\
\text { streamflow } \\
\quad\left(\mathrm{ft}^{3} / \mathrm{s}\right)\end{array}$ & $\begin{array}{l}\text { Simulated } \\
\text { streamflow } \\
\left(\mathrm{ft}^{3} / \mathrm{s}\right)\end{array}$ & $\begin{array}{c}\text { Difference } \\
\quad\left(\mathrm{ft}^{3} / \mathrm{s}\right)\end{array}$ \\
\hline 01211010 & 1.01 & 0.99 & 0.02 \\
\hline 01211040 & 0.54 & 0.71 & -.17 \\
\hline 01211110 & 1.60 & 1.63 & -.03 \\
\hline 01211140 & .22 & .25 & -.03 \\
\hline 01211699 & 1.09 & 1.28 & -.19 \\
\hline 01212550 & .84 & .75 & .08 \\
\hline $\begin{array}{l}01212600 \text { excluding the contribu- } \\
\text { tions from } 01211450,01212550, \\
\text { and } 01211699\end{array}$ & 7.12 & 5.79 & 1.33 \\
\hline
\end{tabular}




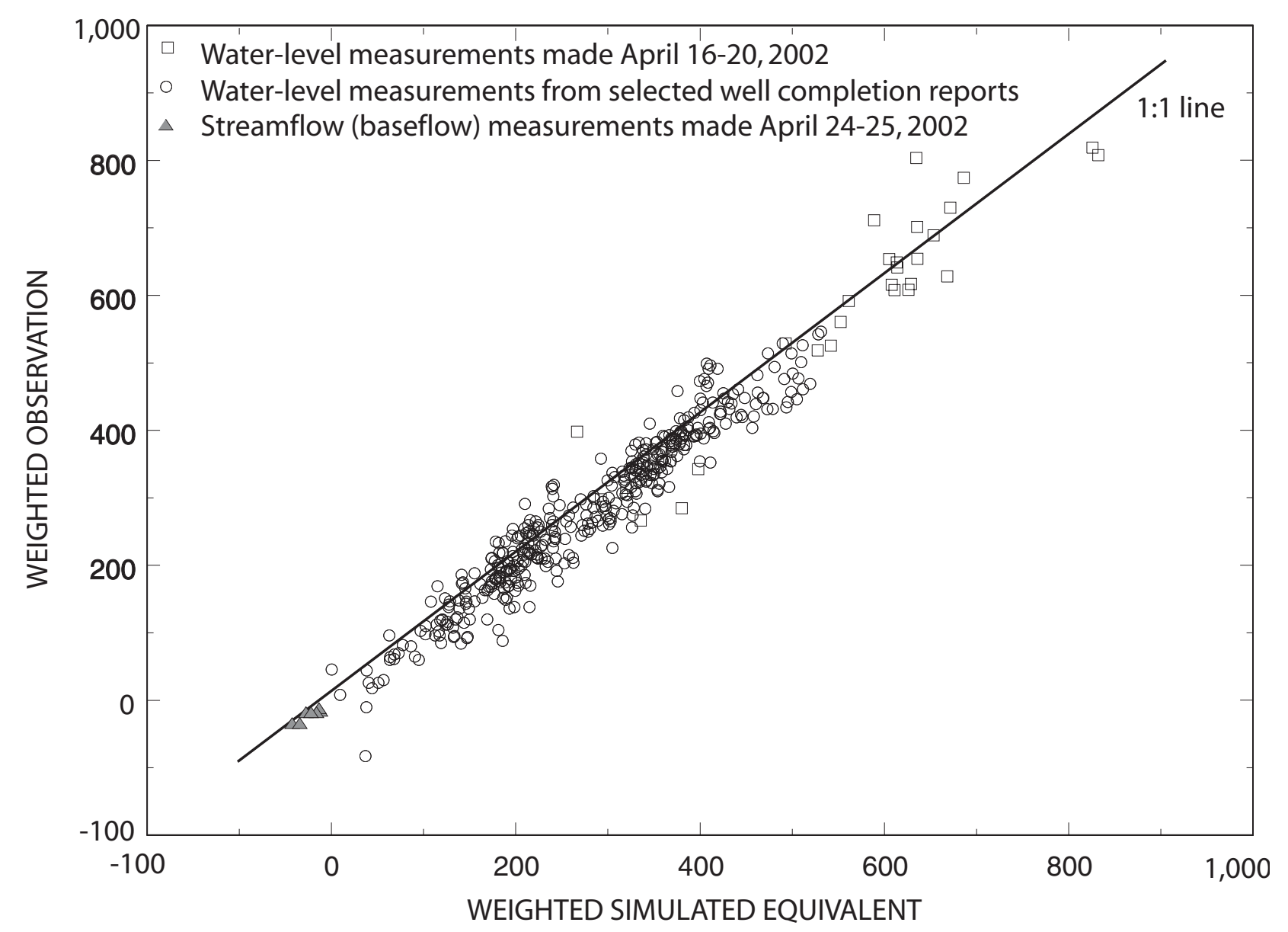

Figure 22. Weighted simulated equivalent plotted against weighted observations of hydraulic head and streamflow for model simulation of the Greenwich area, Connecticut, April 16-24, 2002.

\section{Hydrologic Budget}

The ground-water budget was summarized for two simulations. The first simulation was the modelcalibration phase, based on measurements of water levels and streamflow collected during mid- to late April 2002. For the second simulation, the calibrated model was used with residential ground-water withdrawals adjusted to average daily residential withdrawal rates (tables 14 and 15). The ground-water budget for each basin-based zone (first shown in fig. 13) (tables 14 and 15) was summarized using ZONEBUDGET (Harbaugh, 1990), a computer program that summarizes ground-water budgets for specific zones from MODFLOW-2000 output. Groundwater budgets for this report only include residential withdrawals. Further information is necessary on nonresidential properties.

Components of the ground-water budget for each basin include inputs and outputs. Inputs of water to each basin include recharge from precipitation, discharge from streams and reservoirs to the aquifer, discharge from residential septic systems to the aquifer, and underflow from other basins. Outputs of water from each basin include underflow to other basins, discharge to reservoirs or to Long Island Sound, discharge to streams, and ground-water withdrawals. Consumptive use of ground-water withdrawn from the bedrock aquifer was considered to be negligible during April 2002; therefore, estimates of the residential net consumption of ground water are included only in the model adjusted to average daily ground-water withdrawals (table 15).

Recharge rates from precipitation ranged from 3.9 to $7.5 \mathrm{in} / \mathrm{yr}$ for zones in the model (fig. 23) and are based on the surficial geology and percentage of pervious area of each zone. Leakage from reservoirs or streams to the aquifer was small, and added 0.1$0.8 \mathrm{in} / \mathrm{yr}$ of recharge to the aquifer in some zones. 
Table 14. Annual ground-water budget for modeled zones, based on calibration data from April 18-25, 2002, Greenwich area, Connecticut.

[Based on calibration data from April 16-25, 2002; all values in inches per year; $\mathrm{mi}^{2}$, square miles]

\begin{tabular}{|c|c|c|c|c|c|c|c|c|c|c|}
\hline $\begin{array}{c}\begin{array}{c}\text { Zone } \\
\text { (fig. 23) }\end{array}\end{array}$ & $\begin{array}{l}\text { Area } \\
\left(\mathrm{mi}^{2}\right)\end{array}$ & $\begin{array}{l}\text { Recharge } \\
\text { from pre- } \\
\text { cipitation }\end{array}$ & $\begin{array}{l}\text { Inflow from } \\
\text { reservoirs }\end{array}$ & $\begin{array}{l}\text { Inflow from } \\
\text { streams }\end{array}$ & $\begin{array}{l}\text { Inflow from } \\
\text { residential } \\
\text { septic sys- } \\
\text { tems }\end{array}$ & $\begin{array}{c}\text { Inflow from } \\
\text { other } \\
\text { basins }\end{array}$ & $\begin{array}{c}\text { Outflow to } \\
\text { other } \\
\text { basins }\end{array}$ & $\begin{array}{l}\text { Outflow to } \\
\text { reservoirs } \\
\text { or Long } \\
\text { Island } \\
\text { Sound } \\
\end{array}$ & $\begin{array}{l}\text { Outflow to } \\
\text { streams }\end{array}$ & $\begin{array}{l}\text { Residential } \\
\text { ground-water } \\
\text { withdrawals }\end{array}$ \\
\hline 1 & 1.6 & 5.3 & 0.8 & 0.0 & 0.4 & 2.9 & 2.9 & 0.6 & 5.5 & 0.4 \\
\hline 2 & 1.2 & 6.5 & 0 & .5 & .8 & 2.0 & 2.7 & 0 & 6.2 & .8 \\
\hline 3 & .6 & 6.8 & 0 & 0 & 1.2 & 1.0 & 2.9 & 0 & 4.9 & 1.2 \\
\hline 4 & 3.1 & 6.4 & 0 & 0 & .9 & 2.1 & .9 & 0 & 7.9 & .6 \\
\hline 5 & .9 & 5.9 & 0 & 0 & .1 & 1.2 & 4.9 & 0 & 2.2 & .1 \\
\hline 6 & 1.7 & 7.5 & 0 & .5 & .8 & 2.9 & .3 & 0 & 10.6 & .8 \\
\hline 7 & .8 & 6.4 & 0 & 0 & 1.5 & 1.2 & 4.3 & 0 & 3.3 & 1.5 \\
\hline 8 & 1.6 & 6.4 & 0 & 0 & .9 & 1.9 & 1.0 & 0 & 7.2 & .9 \\
\hline 9 & .3 & 5.5 & 0 & 0 & 1.1 & 1.3 & 1.9 & 0 & 4.9 & 1.1 \\
\hline 10 & 1.4 & 6.6 & 0 & .2 & 1.4 & 1.5 & 2.2 & 0 & 6.2 & 1.4 \\
\hline 11 & 1.1 & 6.9 & 0 & .9 & 1.0 & .7 & 3.8 & 0 & 5.1 & .5 \\
\hline 12 & 1.4 & 6.6 & 0 & 0 & 1.4 & 1.8 & 1.1 & 0 & 7.3 & 1.4 \\
\hline 13 & 2.3 & 6.3 & 0 & 0 & .7 & 1.4 & .5 & .4 & 6.7 & .7 \\
\hline 14 & 1.2 & 6.8 & 0 & 0 & 1.7 & 2.0 & .5 & 0 & 8.9 & 1.1 \\
\hline 15 & 3.5 & 6.7 & 0 & .1 & .9 & 1.2 & .9 & 0 & 8.0 & 0 \\
\hline 16 & 2 & 6.8 & 0 & 0 & .9 & 2.0 & 1.6 & .5 & 6.8 & .9 \\
\hline 17 & 1.7 & 6.7 & 0 & 0 & 1.9 & 1.4 & 1.3 & 0 & 8.5 & .3 \\
\hline 18 & 3 & 4.3 & 0 & 0 & .5 & .8 & .9 & .5 & 4.3 & 0 \\
\hline 19 & 3 & 6.7 & .1 & 0 & 1.2 & .8 & .8 & 0 & 7.0 & 1.1 \\
\hline 20 & 1 & 6.1 & 0 & 0 & 2.1 & 1.5 & 1.3 & 0 & 7.0 & 1.5 \\
\hline 21 & 2.3 & 6.7 & 0 & 0 & 1.8 & 1.1 & 1.5 & 0 & 7.9 & .2 \\
\hline 22 & 1.8 & 6.2 & 0 & 0 & 1.5 & 1.1 & 1.0 & 0 & 7.3 & .5 \\
\hline 23 & 1.2 & 4.1 & 0 & 0 & 1.0 & .7 & .4 & .8 & 4.5 & 0 \\
\hline 24 & .4 & 7.1 & 0 & 0 & 2.6 & 2.0 & 2.2 & 0 & 6.9 & 2.6 \\
\hline 25 & 1.3 & 6.7 & .1 & 0 & 6 & 3.0 & 2.6 & .6 & 6.6 & .6 \\
\hline 26 & 1.5 & 7.0 & 0 & .2 & .9 & .9 & 1.6 & 0 & 6.6 & .9 \\
\hline 27 & 1.1 & 5.7 & 0 & .1 & 1.5 & 3.7 & 1.9 & 0 & 8.4 & .7 \\
\hline 28 & 1.2 & 7.2 & 0 & 0 & 1.9 & 1.4 & .9 & 0 & 8.0 & 1.6 \\
\hline 29 & 1.6 & 5.5 & 0 & 0 & 1.0 & 1.0 & 1.0 & 0 & 6.2 & .2 \\
\hline 30 & 2.7 & 4.9 & 0 & 0 & 1.4 & .9 & 1.6 & .4 & 4.9 & .3 \\
\hline 31 & 2.7 & 4.6 & 0 & 0 & .5 & 1.3 & 1.1 & 1.2 & 3.9 & .1 \\
\hline 32 & 1.8 & 3.6 & 0 & 0 & .5 & .4 & 1.4 & 1.3 & 1.8 & 0 \\
\hline
\end{tabular}


Table 15. Annual ground-water budget for modeled zones, based on calibration data from April 18-25, 2002 and adjusted to average residential water withdrawals, Greenwich area, Connecticut.

[All values in inches per year; $\mathrm{mi}^{2}$, square miles]

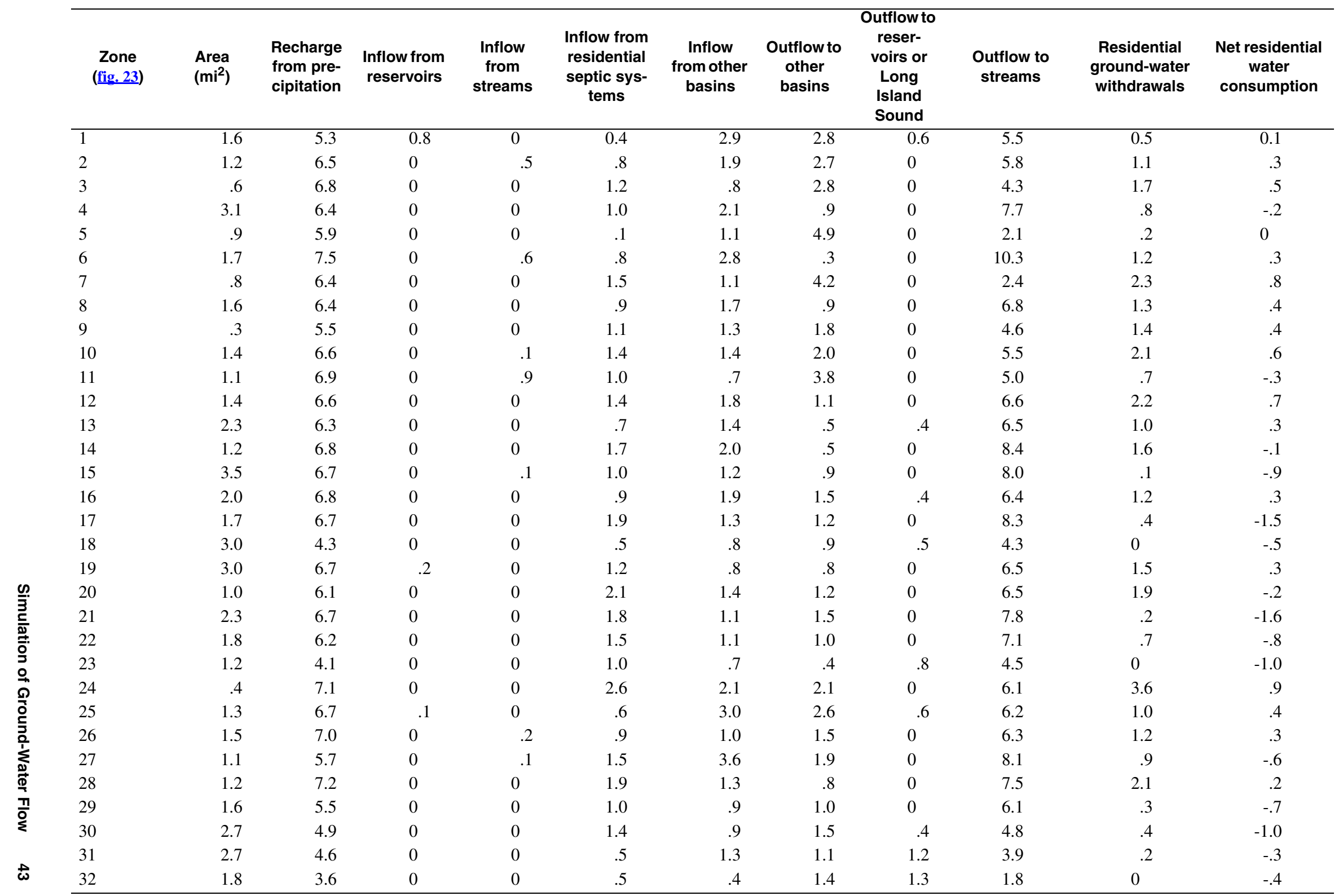




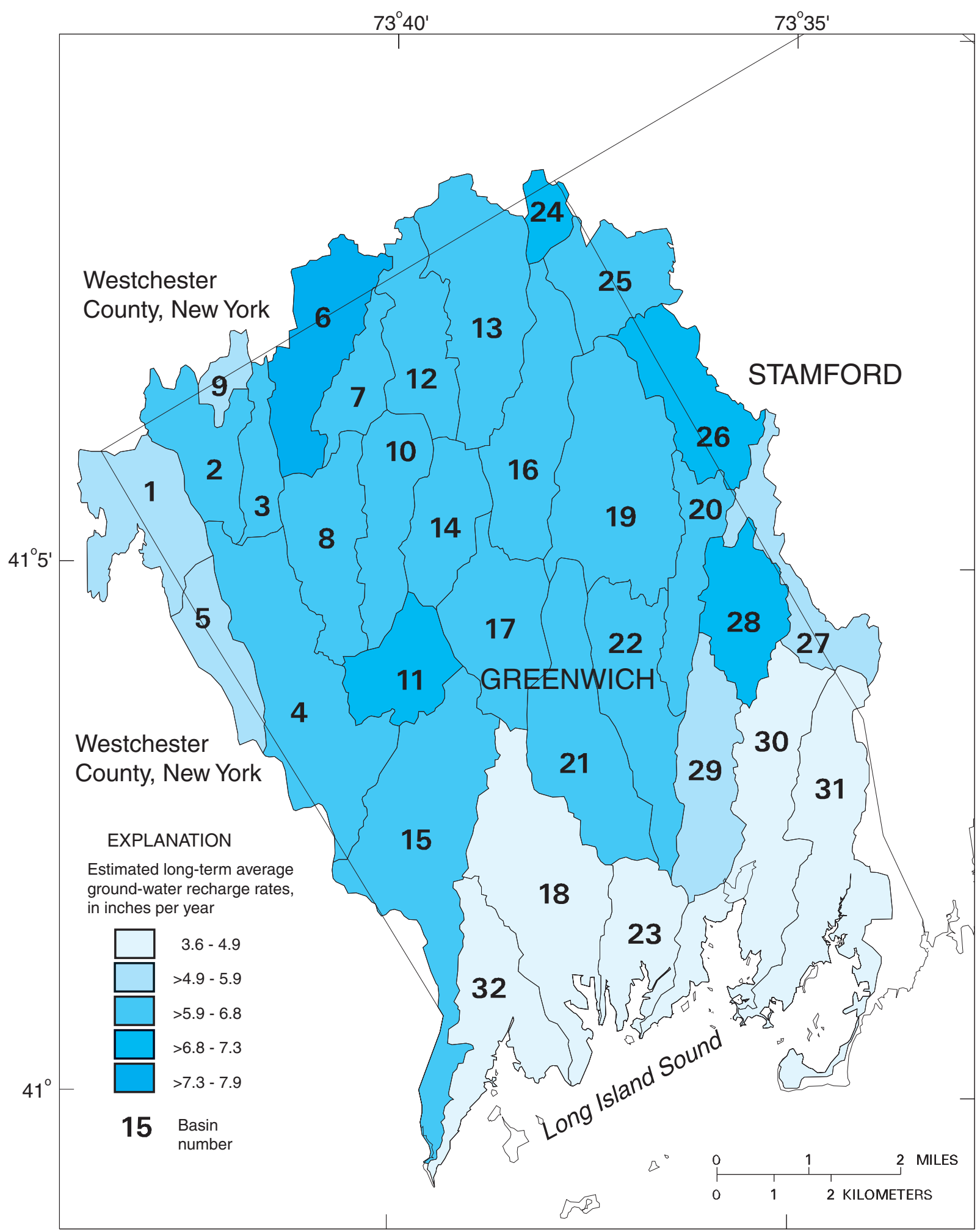

Base from Connecticut Department of Environmental Protection 1994

Digital Line Graph

Projection State Plane Feet Zone 3526

Figure 23. Simulated long-term, average annual ground-water recharge from precipitation aggregated by zones, Greenwich area, Connecticut. 
Inflow from residential septic systems is derived from ground-water withdrawals in the northern part of the Greenwich area and is not a net additional source of recharge over long-term average conditions. The redistribution of this water may be hydrologically important, because it is withdrawn from the deeper aquifer and discharged near the land surface, and therefore may change ground-water flow patterns. For instance, the water may discharge more quickly to a nearby surfacewater body.

In parts of basins with public water supply and septic systems, the discharge from septic systems represents an additional source of recharge. The net amount of additional recharge can be obtained from table 14 or 15 by subtracting residential ground-water withdrawals from inflow from residential septic systems in the calibration model.

In many cases, the outflow to streams in the calibration model (table 14) does not balance with the input of recharge from precipitation. Differences in these two values can be attributed to (1) input of additional sources of recharge described above, (2) underflow among basins, and (3) discharge of water to reservoirs or to Long Island Sound. In the simulation that was adjusted to average residential ground-water withdrawals, differences also can be attributed to consumptive use of ground water. Water-use totals may differ slightly compared to those in the water-use section because of discrepancies in delineating basin boundaries in the model grid and assigning a zone/basin code to each model cell.

Net annual consumptive residential water use was determined by subtracting the simulated input from septic systems from the average annual groundwater withdrawals in each zone (table 15). Some basins that have withdrawals of ground water have greater input from septic systems supplied by public water supply; therefore, the net residential consumption of ground water is zero (fig. 24) or is shown as a negative number in table 15. 


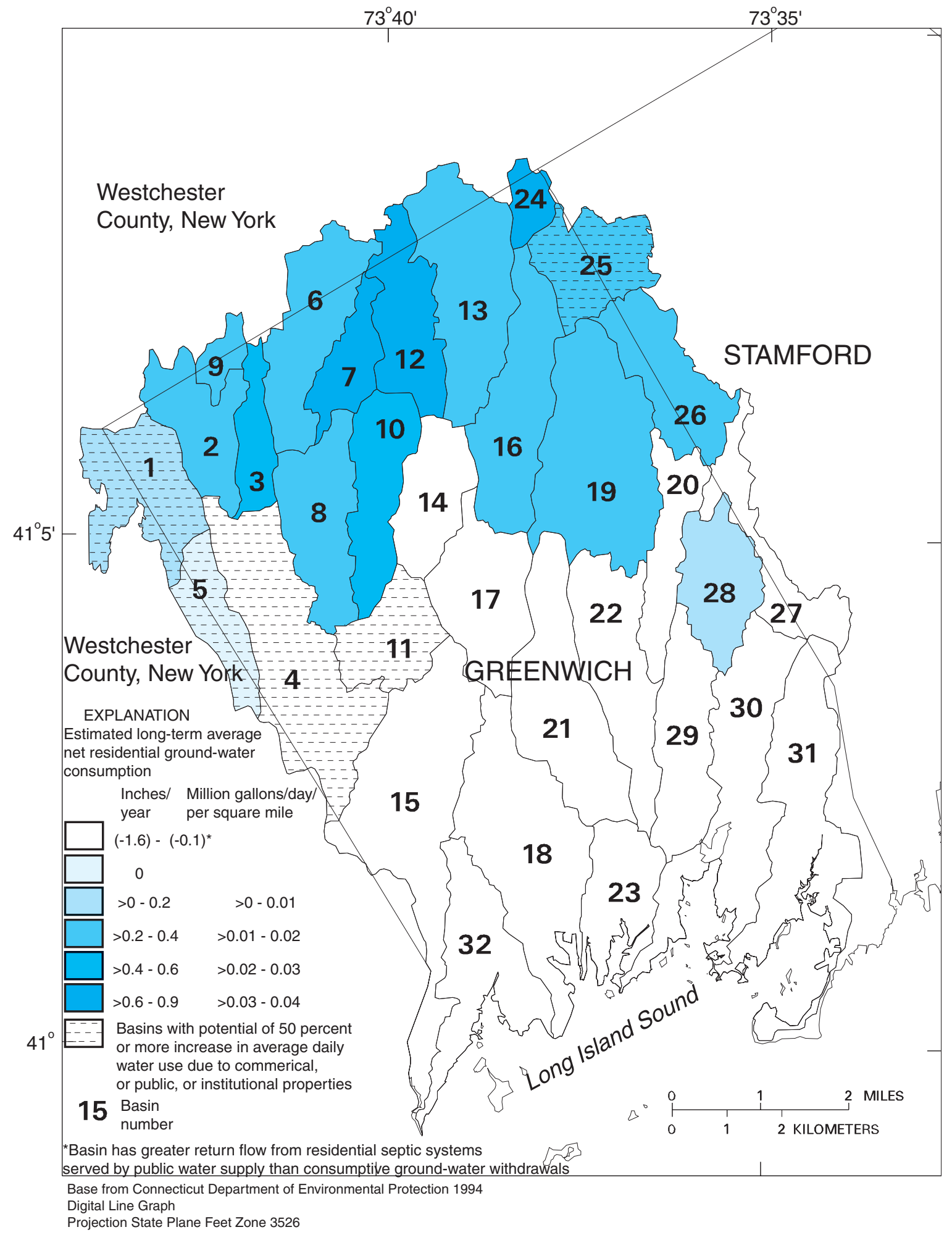

Figure 24. Simulated long-term average net residential consumptive water use for zones, Greenwich area, Connecticut. 


\section{GROUND-WATER AVAILABILITY IN THE GREENWICH AREA}

Ground water is an important part of the water budget in Greenwich providing, at minimum, an estimated 35 percent of the annual streamflow (see eq. 1). This base flow contributes to maintaining river habitat and aquatic life, providing inflow to public watersupply reservoirs, and providing water to ponds used for fire protection during periods of little overland runoff.

Determination of ground-water availability should consider what changes to the water budget of a particular basin might be acceptable. Changes to the water budget due to withdrawals may include decrease in base flow of streams, increase in the recharge from surface-water bodies, or the capture of ground water that would have originally been lost through groundwater evapotranspiration in wetlands and other areas with shallow water tables. One method to determine the status of each basin is to examine various streamflow criteria in comparison to the current water budget. To show this current status, several equations that predict statistical low streamflows were compared to the conditions described in the above section on groundwater budgets.

Weiss (1983) produced equations based on streamflow statistics in Connecticut to determine the 7day 10-year low flow $\left(\mathrm{Q}_{7,10}\right)$, the 7-day 2-year low flow $\left(\mathrm{Q}_{7,2}\right)$, and the 30-day 2-year low flow $\left(\mathrm{Q}_{30,2}\right)$. The $\left(\mathrm{Q}_{7,10}\right)$ is the lowest flow for 7 consecutive days with a recurrence interval of 10 years, the $\left(Q_{7,2}\right)$ is the lowest flow for 7 consecutive days with a recurrence interval of 2 years, and the $\left(Q_{30,2}\right)$ is the lowest flow for 30 consecutive days with a recurrence interval of 2 years.

The $\left(\mathrm{Q}_{7,10}\right)$ in Connecticut is considered to be the minimum amount of water required to assimilate wastewater (Connecticut Department of Environmental Protection, 1997). The $\left(\mathrm{Q}_{7,2}\right)$ and $\left(\mathrm{Q}_{30,2}\right)$ are statistical determinations of the typical summer flows of streams in Connecticut and probably represent periods of typical annual low base flow.
Equations for these streamflows from Weiss (1983) are:

$$
\begin{aligned}
& \left(\mathrm{Q}_{7,10}\right) / \mathrm{A}=0.0065(\% \mathrm{Asd}+1)-0.001 \\
& \left(\mathrm{Q}_{7,2}\right) / \mathrm{A}=0.0104(\% \mathrm{Asd}+1)-0.001 \\
& \left(\mathrm{Q}_{30,2}\right) / \mathrm{A}=0.0124(\% \mathrm{Asd}+1)-0.001
\end{aligned}
$$

where

$$
Q \text { is the specified discharge, in cubic }
$$
feet per second,

$A$ is basin drainage area, in square miles, and

$\%$ Asd is the percentage of the basin containing coarse-grained glacial stratified deposits (glacial stratified deposits).

The specified flows are larger for basins containing larger percentages of glacial stratified deposits because of the greater recharge rates and the ability to store and transmit water.

Long-term average base flows predicted by the ground-water-flow simulation based on residential ground-water withdrawals are, in most cases, substantially greater than the low streamflow statistical criteria (fig. 25). The water budget for many of the basins probably is different now compared to pre-development conditions because of ground-water consumption and increasing urbanization.

In general, basins with consumptive residential use of ground water have long-term estimated average base flows that are lower than basins with little or no consumptive use. Some of the basins with little or no consumptive use of ground water (for example, basins 31 and 32; fig. 21), however, are estimated to have reduced recharge rates due to urbanization, and therefore the estimated base flows approach low-streamflow criteria. 

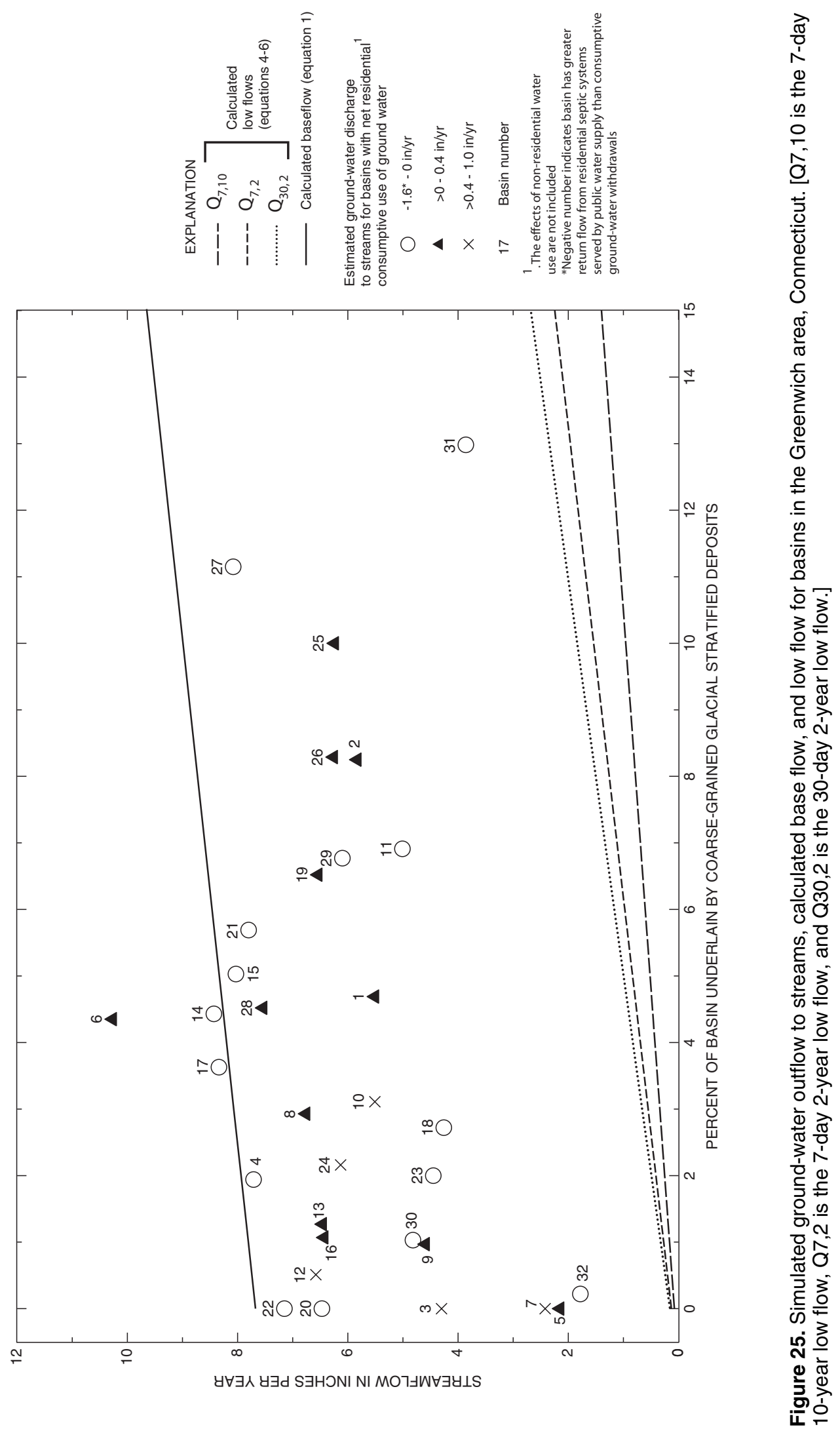
When current estimated net residential groundwater consumptive use is compared to recharge rates for each zone in the study area (table 16), it can be seen that ground-water consumption is, in most cases, small. One criteria that might be used to make comparisons among zones in the Greenwich area is to subtract the $\mathrm{Q}_{30,2}$ from the recharge (from precipitation) for each basin normalized to drainage area. This sample criteria is conservative in the respect that it does not include additional recharge from septic systems or underflow from other basins. The basins with the largest relative estimated net residential consumptive water use include zones 7, 10, 12, and 24. It is estimated that for these zones, about 10 percent or more of the difference between long-term average recharge and the $\mathrm{Q}_{30,2}$ is being used (table 16).

This sample criteria, although useful on a comparative basis, does not take into account other issues including (1) the additional nonresidential water use; (2) the physical plausibility of being able to capture the difference between the recharge and the $\mathrm{Q}_{30,2}$ by pumping; (3) the localized effects of lowering the water table on nearby wells, or on the habitat contained within wetlands and watercourses; and (4) the effects on summer streamflows (for example, if the average base flow is lowered to the $\mathrm{Q}_{30,2}$, summer base flow also will be substantially lower).

Output data from these ground-water models can be used to determine the current status of ground-water use relative to recharge or other water-budget criteria. In order for this data to be used properly, several qualifications and assumptions should be discussed.

In the ground-water flow simulations conducted for this study, it was assumed that impervious areas do not receive any recharge. Estimates of recharge from the nonlinear parameter estimation algorithm in MODFLOW were matched to streamflow observations and water levels to obtain the best fit for recharge to till deposits assuming no recharge beneath impervious areas. The recharge to urbanized basins is therefore reduced. It is believed that these estimates are conservative and that more research is needed in this area to determine the effects of impervious cover and alternative stormwater management on recharge and base flow.

Table 16. Estimated net annual residential consumptive water use and the difference between estimated long-term average recharge and the 30-day 2-year low flow.

[Zones not shown in this table are estimated to have no net consumptive residential use of water; $\mathrm{Q}_{30,2}$, 30-day 2-year low flow]

\begin{tabular}{cccccc}
\hline $\begin{array}{c}\text { Zone } \\
\text { (fig. 22) }\end{array}$ & $\begin{array}{c}\text { Recharge } \\
\text { (inches) }\end{array}$ & $\begin{array}{c}\text { Water consump- } \\
\text { tion (inches) }\end{array}$ & $\begin{array}{c}\mathbf{Q}_{\mathbf{3 0 , 2}} \\
\text { (inches) }\end{array}$ & $\begin{array}{c}\text { Difference between } \\
\text { recharge and } \mathbf{Q}_{\mathbf{3 0 , 2} 2} \\
\text { (inches) }\end{array}$ & $\begin{array}{c}\text { Percentage of } \\
\text { difference consumed }\end{array}$ \\
\hline 1 & 5.3 & 0.13 & 0.9 & 4.4 & 2.9 \\
2 & 6.5 & 0.33 & 1.5 & 4.9 & 6.6 \\
3 & 6.8 & 0.49 & 0.2 & 6.7 & 7.4 \\
5 & 5.9 & 0.03 & 0.2 & 5.8 & 0.6 \\
6 & 7.5 & 0.33 & 0.9 & 6.6 & 13.0 \\
7 & 6.4 & 0.81 & 0.2 & 6.2 & 6.7 \\
8 & 6.4 & 0.38 & 0.6 & 5.7 & 6.8 \\
9 & 5.5 & 0.35 & 0.3 & 5.2 & 10.6 \\
10 & 6.6 & 0.63 & 0.7 & 6.0 & 11.6 \\
12 & 6.6 & 0.74 & 0.2 & 6.3 & 5.7 \\
13 & 6.3 & 0.34 & 0.4 & 5.9 & 5.0 \\
16 & 6.8 & 0.32 & 0.3 & 6.5 & 5.6 \\
19 & 6.7 & 0.31 & 1.3 & 5.5 & 14.3 \\
24 & 7.1 & 0.94 & 0.5 & 6.6 & 8.0 \\
26 & 6.7 & 0.38 & 1.8 & 4.8 & 6.4 \\
\hline
\end{tabular}


Residential water use was documented for this study, but there may be additional substantial groundwater withdrawals for commercial, institutional, and public buildings and golf courses. As shown in figure 12, additional water is used in some basins that requires further research.

Water that has been returned to the aquifer by septic systems is assumed to remain in the basin as part of the water budget. In reality, some of this water may never recharge the bedrock aquifer, and may discharge to a nearby surface-water body and not be available for reuse. In the model simulations, return flow from septic systems was greater than ground-water withdrawals in nearly half of the basins studied (because of input from private septic systems at properties served by public water supplies), indicating that this is an important component of the water budget in the Greenwich area.

Wells drilled into the bedrock underlying glacial stratified deposits may have more water available under pumping stresses, if there is a good hydraulic connection between these coarse-grained deposits and the underlying bedrock, due to the storage characteristics of this aquifer.

Data and interpretation of the water budget are provided for 32 basin-based zones (tables 14, 15). Human activities, including new development and ground-water withdrawals, may have different effects depending on their location in these basins. For instance, concentrated development with ground-water withdrawals near the headwaters of a basin may have a more localized effect on the water budget (that is, streamflow reduction or reduction in ground-water levels) than the same development if farther downstream in the basin, even though the overall change in pumping might not be large relative to the water budget for the entire basin. The potential for large fluctuation in water levels is greater in the hilltop setting and is less apparent in the valley bottom, due to ground-water contributions from upgradient parts of the basin (fig. 10).

Recharge rates and water budgets presented in this report are not fixed numbers, and the ground-water budget for any basin is dynamic. Changes in development in a particular basin may have consequences in addition to changes caused by increased withdrawal and use of ground-water. These changes include changes to recharge rates caused by impervious surfaces, changes to the water budgets of other basins (in the case where underflow from one basin to another is important), and the possibility of increased recharge if new development takes place in areas with public water supply and septic systems. The addition of sanitary sewers to areas with private wells can export water from a basin, and therefore affect ground-water availability. Other changes to the water budget include longterm changes in annual precipitation, changes in the seasonal variability of precipitation, or prolonged drought.

\section{WATER QUALITY IN THE GREENWICH AREA}

Analyses of seven surface-water-quality samples collected during base flow showed that concentrations of some indicators of water-quality degradation were higher in more urbanized basins than in less urbanized basins (fig. 26; table 17). Concentrations of total nitrogen, total phosphorus, chloride, indicator bacteria, and the number of different pesticide detections were generally higher with increasing urbanization of the basin. Samples from one site (USGS station number 01211210), collected below a point of water diversion and storage, may not be entirely representative of the base-flow conditions of the lower part of Horseneck Brook (fig. 2).

The U.S. Environmental Protection Agency (USEPA) has set regional nutrient-criteria guidelines for State governments for determination of impaired waters (U.S. Environmental Protection Agency, 2000; 2001). The criteria for total nitrogen for Ecoregion XIV (which includes Connecticut) is $0.7 \mathrm{mg} / \mathrm{L}$ for rivers and streams and $0.32 \mathrm{mg} / \mathrm{L}$ for lakes and reservoirs. The criteria for total phosphorus is $0.031 \mathrm{mg} / \mathrm{L}$ for rivers and streams and $0.008 \mathrm{mg} / \mathrm{L}$ for lakes and reservoirs. These criteria are considered a starting point in determining problem areas, and State governments may set more stringent criteria.

Nitrogen and phosphorus concentrations above ambient concentrations may originate from atmospheric deposition, septic systems, lawn fertilizers, waterfowl, and from point-source discharges. Elevated nitrogen concentrations are of concern for eutrophication and hypoxia in Long Island Sound (Long Island Sound Study, 1998) because nitrogen is the limiting nutrient in saltwater bodies. Data interpreted from Mullaney and others (2002) indicate that concentrations of total nitrogen in mostly forested basins range on average from 0.35 to $0.5 \mathrm{mg} / \mathrm{L}$. As basins become 


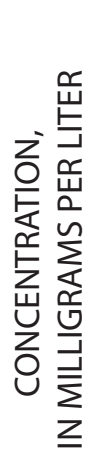
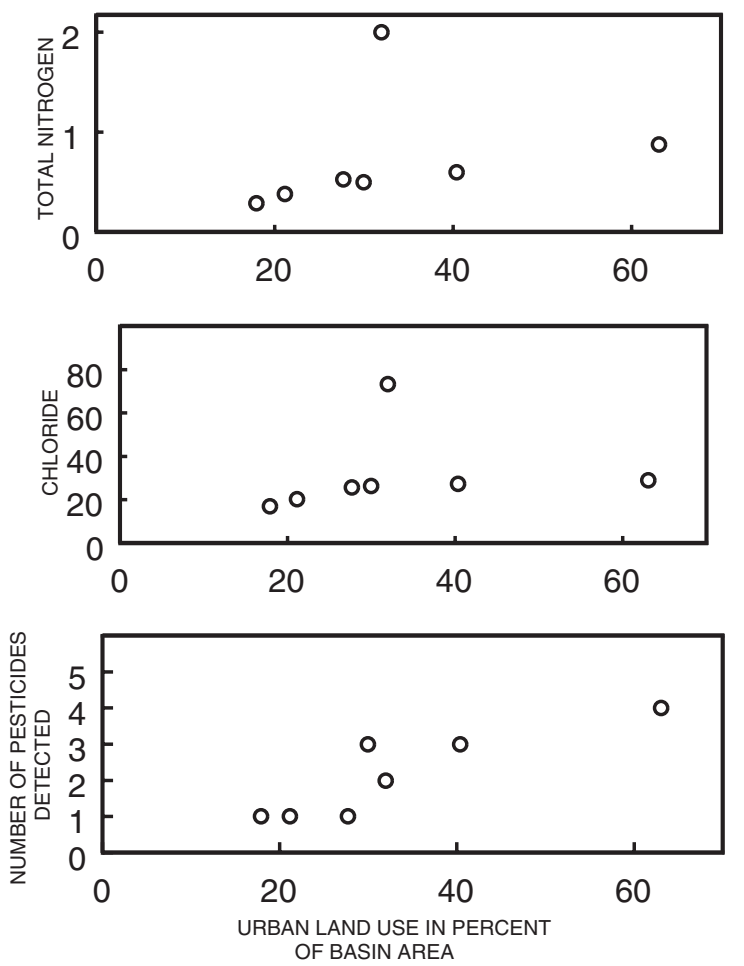
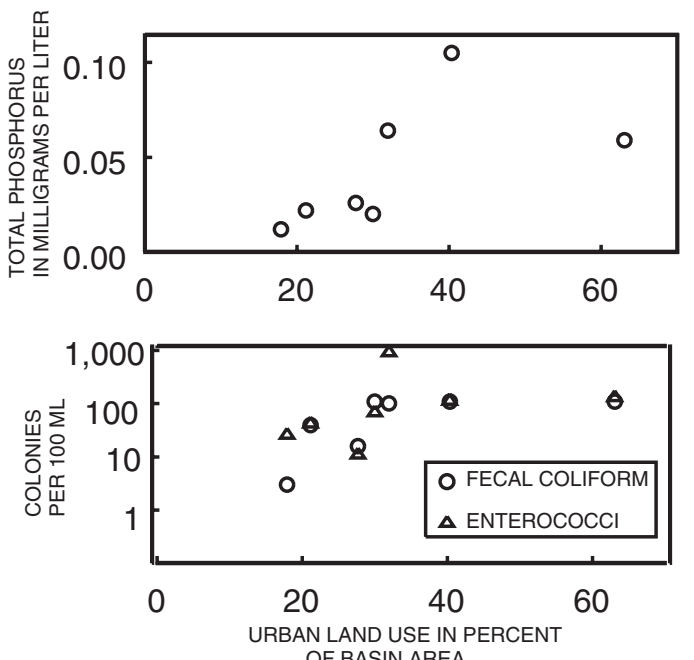

Figure 26. Percentage of urban land use and concentrations of selected water-quality constituents, Greenwich area, Connecticut.

Table 17. Percentage of urban land use and concentration of selected water-quality constituents in surface-water base-flow samples collected October 2000, Greenwich area, Connecticut.

[Urban land use determined from Civco and others (1998) by summing total area of each basins from the following land use/land cover categories: "Commercial, industrial, pavement; residential and commercial; rural residential; turf and tree complex; and turf and grass; USGS, U.S. Geological Survey; $\mathrm{mg} / \mathrm{L}$, milligrams per liter; $\mathrm{mL}$, milliliters]

\begin{tabular}{|c|c|c|c|c|c|c|c|}
\hline $\begin{array}{c}\text { USGS } \\
\text { station } \\
\text { identification } \\
\text { number } \\
\text { (fig. 2) }\end{array}$ & $\begin{array}{c}\text { Urban land } \\
\text { use } \\
\text { (percentage } \\
\text { of } \\
\text { basin area) }\end{array}$ & $\begin{array}{c}\text { Total } \\
\text { nitrogen } \\
\text { concentration } \\
(\mathrm{mg} / \mathrm{L})\end{array}$ & $\begin{array}{c}\text { Total } \\
\text { phosphorus } \\
\text { concentration } \\
(\mathrm{mg} / \mathrm{L})\end{array}$ & $\begin{array}{c}\text { Chloride } \\
\text { concentration } \\
(\mathrm{mg} / \mathrm{L})\end{array}$ & $\begin{array}{c}\text { Fecal } \\
\text { coliform bac- } \\
\text { teria } \\
\text { (colonies per } \\
100 \mathrm{~mL} \text { ) }\end{array}$ & $\begin{array}{c}\text { Enterococci } \\
\text { bacteria } \\
\text { (colonies per } \\
100 \mathrm{~mL} \text { ) }\end{array}$ & $\begin{array}{c}\text { Number of } \\
\text { different } \\
\text { pesticides } \\
\text { detected }\end{array}$ \\
\hline 01211600 & 32.0 & 2.00 & 0.064 & 73.2 & 100 & 920 & 2 \\
\hline 01211140 & 21.1 & .380 & .022 & 20.4 & 40 & 42 & 1 \\
\hline 01211210 & 40.3 & .600 & .105 & 27.4 & 110 & 112 & 3 \\
\hline 01211010 & 27.7 & .530 & .026 & 25.7 & 16 & 11 & 1 \\
\hline 01211699 & 17.9 & .290 & .012 & 17.0 & 3 & 26 & 1 \\
\hline 01211110 & 63.1 & .880 & .059 & 29.0 & 110 & 132 & 4 \\
\hline 01212100 & 30.0 & .500 & .020 & 26.4 & 110 & 68 & 3 \\
\hline
\end{tabular}


more urbanized, concentrations of total nitrogen due to nonpoint sources of nitrogen may range from less than $0.5 \mathrm{mg} / \mathrm{L}$ to $2.0 \mathrm{mg} / \mathrm{L}$. Basins containing municipal wastewater-treatment facilities may have total nitrogen concentrations as high as $5 \mathrm{mg} / \mathrm{L}$ or more if the wastewater is a large part of the total streamflow. Grady and Mullaney (1998) and Grady (1994) determined that median nitrate (the most common form of nitrogen in ground water) plus nitrite nitrogen concentrations in shallow ground-water beneath urbanized areas ranged from 1.1 to $2.4 \mathrm{mg} / \mathrm{L}$, as compared with 0.11 to 0.14 $\mathrm{mg} / \mathrm{L}$ in shallow ground water beneath forested areas. Heisig (2000) determined that nitrate nitrogen concentrations in stream base flow were positively correlated to unsewered housing density in the nearby Croton Basin in New York.

Elevated phosphorus concentrations are of concern for algal blooms and eutrophication in freshwater bodies, where phosphorus is the limiting nutrient. Concentrations of total phosphorus in excess of $0.1 \mathrm{mg} / \mathrm{L}$ in moving water in streams may cause algal blooms or excessive nuisance plant growth (Litke, 1999). Concentrations lower than $0.1 \mathrm{mg} / \mathrm{L}$ may be able to cause algal blooms in lakes and ponds.

A water sample from an unnamed tributary to Greenwich Creek (USGS station number 01211110, fig. 2) was analyzed using an experimental procedure for wastewater compounds (Kolpin and others, 2002) to determine if this location (the most urbanized basin sampled) showed signs of input from septic systems. The compounds that were detected were present at very low concentrations-at, near, or below the reporting limits. Concentrations of most of the compounds are estimated due to the experimental nature of the analysis. The compounds detected (table 18) indicate that wastewater from septic systems or leaking sanitary sewer lines has entered this stream. The same compounds were detected in a national survey of pharmaceuticals, hormones, and other organic wastewater compounds (Kolpin and others, 2002).

Table 18. Wastewater compounds detected on October 25, 2000 at station number 01211110 , Greenwich Connecticut.

[E, estimated concentration]

\begin{tabular}{lcl}
\hline \multicolumn{1}{c}{ Wastewater compound } & $\begin{array}{c}\text { Concentration } \\
\text { (micrograms per liter) }\end{array}$ & \multicolumn{1}{c}{ Use or indication } \\
\hline Para-nonylphenol-total & E 0.223 & Nonionic detergent metabolite \\
Nonylphenol monoethoxylate- (NPEO1) (total) & E 0.531 & Nonionic detergent metabolite \\
Nonylphenol diethoxylate- (NPEO2) (total) & E 0.933 & Nonionic detergent metabolite \\
Triclosan & 0.051 & Anti-bacterial/disinfectant \\
3-beta-coprostanol & E 0.428 & Fecal indicator \\
\hline
\end{tabular}




\section{SUMMARY AND CONCLUSIONS}

Water use, ground-water availability, and quality of water were studied by the U.S. Geological Survey (USGS) in cooperation with the town of Greenwich, Connecticut, during 2000-02. The study area is 52.8 square miles and includes Greenwich, part of Stamford, Connecticut, and adjacent parts of Westchester County, New York. Increasing development and the lack of large glacial stratified aquifers for public water supply have led to a need to study groundwater availability and water use in basins in the Greenwich area. Self-supplied ground water from a fractured crystalline-bedrock aquifer is the source of water supply to about 12 percent of the households in the Greenwich area.

Households with public water supply (from a surface-water source) in Greenwich used from 219 to $1,082 \mathrm{gal} / \mathrm{d}$ of water during 2000 . Water use at these properties was less during the winter season (204 to $848 \mathrm{gal} / \mathrm{d}$ ) and more during the summer season (230 to $1,389 \mathrm{gal} / \mathrm{d})$. Water use was strongly dependent on the type and size of the residential property. Three multiple-linear regression models were used to estimate self-supplied water use (from a ground-water source) for average daily, winter, and summer conditions in 32 basin-based zones. The winter water-use model also was used to estimate return flow in areas with public water supply and septic systems. The regression models were developed with GIS characteristics of properties that were matched to a database of public water-supply information. Statistically significant predictors of water use included the amount of unforested area, the area of outside swimming pools, the sum of areas covered with buildings, and lot size. Estimates of average residential daily ground-water withdrawals by basin ranged from 0 to 0.16 million gallons per day per square mile $\left(\mathrm{Mgal} / \mathrm{d} / \mathrm{mi}^{2}\right)$, and totaled about 2.1 million gallons per day $(\mathrm{Mgal} / \mathrm{d})$. The estimated return flow from residential septic systems on properties served by public water supply ranged from 0 to $0.08 \mathrm{Mgal} / \mathrm{d} / \mathrm{mi}^{2}$, and totaled $1.4 \mathrm{Mgal} / \mathrm{d}$.

Residential consumptive water use in Greenwich was estimated to be about 20 percent of average daily water use, based on comparison of data aggregated by basin for seasonal regression models. Additional water use at nonresidential properties, including golf courses, churches, schools, and commercial properties, may amount to a 50-percent or more increase in average daily ground-water use in 5 of the 32 basin areas studied.

A steady-state finite-difference ground-waterflow model was used to study the water budgets of the 32 basins in the study area. The ground-water-flow model was calibrated to streamflow measurements, water levels measured in private wells during April 2002, and additional water levels reported on wellcompletion reports. Optimal values for hydraulic conductivity of the bedrock aquifer and recharge to till were estimated in the model using nonlinear regression. Ground-water recharge was not applied to impervious areas in the model. Impervious areas were estimated for each model cell from GIS information provided by the town of Greenwich, or from extrapolation of this information using interpreted LANDSAT imagery. The ground-water recharge to till deposits that cover most of the study area was estimated to be 6.9 inches per year. Average (bulk) hydraulic conductivity of the bedrock was estimated to be 0.05 feet per day.

The calibrated ground-water-flow model was used to simulate average daily residential ground-water withdrawals, and water budgets were summarized by basin. Simulated long-term ground-water recharge by basin ranged from 3.9 to $7.9 \mathrm{in} / \mathrm{yr}$. Basins with the smallest amount of recharge were primarily along the coastal sections of Greenwich where the degree of urbanization is greatest. Net consumptive residential ground-water use ranged from 0 to $0.9 \mathrm{in} / \mathrm{yr}$. The largest net consumptive residential ground-water use was from small basins in the upper reaches of the East Branch of the Byram River Basin and in part of the Mianus River Basin in the Banksville section of Greenwich.

Water-budget components were compared to statistically based calculations of average base flow and several low flows, including the 30-day 2-year flow $\left(\mathrm{Q}_{30,2}\right)$, the 7-day 2-year flow $\left(\mathrm{Q}_{7,2}\right.$, and the 7-day 10year $\left(Q_{7,10}\right)$ so that relative comparisons could be made among basins. A criteria of subtracting the $\mathrm{Q}_{30,2}$ from the estimated recharge for each basin was used as one possible estimate of ground-water availability. Based on this criteria, net residential ground-water consumption ranged from 0 to 14.3 percent of available water. Simulated streamflows (long-term average base flows) for each basin also were compared to the statistical calculation of base flow and low flow to determine if any of the long-term average simulated base flows approached these criteria. Possible reductions in base 
flow were noted in many basins that had either relatively large ground-water withdrawals or in basins with a high degree of urbanization. Two coastal basins and one basin in north-central Greenwich had simulated streamflows of less than 3 in/yr and approached statistical low flows.

Users of this information should note that a percentage of the recharge in each basin (including, for example, artificial recharge from septic systems) may never enter the bedrock aquifer and may be unavailable for use. Changes to the water budget caused by new development in any basin may be more pronounced in the headwaters of a basin than in the downstream valley bottom, in terms of the localized effect on streamflow and ground-water levels.

The water budgets estimated in this report are not fixed because the aquifer is a dynamic system. Changes in development in one basin may have effects on the water budgets of other basins, or may not be apparent for many years. New and existing development may have effects, in addition to ground-water withdrawals, on the water budget, such as loss of recharge, change in recharge patterns, or re-routing ground water through septic systems.

Results of the limited base-flow water-quality sampling indicate that the water quality is related to the degree of urbanization. Concentrations of nitrogen, phosphorus, chloride, and indicator bacteria appear to be related to the percentage of urban land in each of the basins sampled. More urbanized basins had detections of a larger number of pesticides, but concentrations were very low. In three basins, phosphorus concentrations were higher than regional nutrient criteria for rivers and streams and may cause excess algal growth. Total nitrogen concentrations exceeded regional nutrient criteria for lakes and ponds in water samples from six of seven basins sampled, indicating concentrations above ambient levels.

\section{REFERENCES CITED}

American Water Works Association Research Foundation, 1999, Residential end uses of water: Denver, Colorado, $310 \mathrm{p}$.

Bauer, H.H, and Mastin, M.C., 1997, Recharge from precipitation in three small glacial-till mantled catchments in the Puget Sound Lowland, Washington: U.S. Geological Survey Water-Resources Investigations Report 964219, $119 \mathrm{p}$.
Civco, D.L., Arnold, C.L., Hurd, J.D., 1998, Land use and land cover mapping for the Connecticut and New York portions of the Long Island Sound Watershed: Office of Long Island Sound Programs, Connecticut Department of Environmental Protection, Research Project CWF 330-R Technical Completion Report, unpaginated.

Cohn, T.A., DeLong, L.L., Gilroy, E.J., Hirsch, R.M., and Wells, D.K., 1989, Estimating constituent loads: Water Resources Research, v. 25, no. 5, p. 937-942.

Cooley, R.L., and Naff, R.L., 1990, Regression modeling of ground-water flow: U.S. Geological Survey Techniques of Water Resources Investigations, book 3, chap. B4, $232 \mathrm{p}$.

Grady, S.J., 1994, Effects of land use on quality of water in stratified-drift aquifers in Connecticut-Chapter B, Analysis of nonpoint-source ground-water contamination in relation to land use: U.S. Geological Survey Water-Supply Paper 2381, 56 p.

Grady, S.J., and Mullaney, J.R., 1998, Natural and human factors affecting shallow water quality in surficial aquifers in the Connecticut, Housatonic, and Thames River Basins: U.S. Geological Survey Water-Resources Investigations Report 98-4042, 81 p.

Gregory, H.E., and Ellis, A.J., 1916, Ground water in the Hartford, Stamford, Salisbury, Willimantic, and Saybrook areas, Connecticut: U.S. Geological Survey Water-Supply Paper 374, $150 \mathrm{p}$.

Harbaugh, A.W., 1990, A computer program for calculating subregional water budgets using results from the U.S. Geological Survey modular three-dimensional groundwater flow model: U.S. Geological Survey Open-File Report 90-392, 46 p.

Harbaugh, A.W., Banta, E.R., Hill, M.C., and McDonald, M.G., 2000, MODFLOW-2000, The U.S. Geological Survey modular ground-water model-User guide to modularization concepts and the ground-water flow process: U.S. Geological Survey Open-File Report 0092, $121 \mathrm{p}$.

Heisig, P.M., 2000, Effects of residential and agricultural land uses on the chemical quality of baseflow of small streams in the Croton watershed, southeastern New York: U.S. Geological Survey Water-Resources Investigations Report 99-4173, 15 p.

Helsel, D.R., and Hirsch, R.M., 1992, Statistical methods in water resources: Amsterdam, Elsevier, 529 p.

Hill, M.C., Banta, E.R., Harbaugh, A.W., and Anderman, E.R., 2000, MODFLOW-2000, The U.S. Geological Survey modular ground-water model-User guide to the observation, sensitivity, and parameter-estimation processes and three post-processing programs: U.S. Geological Survey Open-File Report 00-184, 209 p.

Hill, M.C., 1998, Methods and guidelines for effective model calibration: U.S. Geological Survey Water Resources Investigations Report 98-4005, 90 p. 
Hunter, B.D., and Meade, D.B., 1983, Precipitation in Connecticut, 1951-80: Connecticut Department of Environmental Protection Bulletin 6, 92 p.

Kolpin, D.W., Furlong, E.T., Meyer, M.T., Thurman, E.M., Zaugg, S.D., Barber, L.B., and Buxton, H.T., 2002, Pharmaceuticals, hormones, and other organic wastewater contaminants in U.S. streams, 1999-2000-A national reconnaissance: Environmental Science and Technology, v. 36, no. 6, p. 1202-1211.

Kontis, A.L., 2001, Computer program for simulation of variable recharge with the U.S. Geological Survey modular finite difference ground-water flow model (MODFLOW): U.S. Geological Survey Open-File Report 00-173, 75 p.

Litke, D.W., 1999, Review of phosphorus control measures in the United States and their effects on water quality: U.S. Geological Survey Water-Resources Investigations Report 99-4007, 38 p.

Long Island Sound Study, 1998, Phase III actions for hypoxia management: U.S. Environmental Protection Agency, 28 p.

Mazzaferro, D.L., 1986, Ground-water availability and water quality in Southbury and Woodbury, Connecticut: U.S. Geological Survey Water-Resources Investigations Report 84-4221, 105 p.

Mazzaferro, D.L., Handman, E.H., and Thomas, M.P., 1979, Water resources inventory of Connecticut, part 8, Quinnipiac River Basin: Connecticut Water Resources Bulletin 27, 88 p.

Melvin, R.L., 1986, Connecticut observation wells-Guidelines for network modification: U.S. Geological Survey Water-Resources Investigations Report 85-4079, 24 p.

Melvin, R.L., Stone, B.D., Stone, J.R., and Trask, N.J., 1992, Hydrogeology of thick till deposits in Connecticut: U.S. Geological Survey Open-File Report 92-43, 43 p. (Reprinted as part of Connecticut Department of Environmental Protection Bulletin 20.)

Morrison, Jonathan, Davies, B.S., 3rd, Martin, J.W., Norris, J.R., 2003, Water resources data, Connecticut, water year 2002: U.S. Geological Survey Water-Data Report CT-02-1, 377 p.

Morrison, Jonathan, Provencher, P.L., Martin, J.W., Norris, J.R., 2002, Water resources data, Connecticut, water year 2001: U.S. Geological Survey Water-Data Report CT-01-1, 353 p.

Mullaney, J.R., Mondazzi, R.A., and Stone, J.R., 1999, Hydrogeology and water quality of the Nutmeg Valley area, Wolcott and Waterbury, Connecticut: U.S. Geological Survey Water-Resources Investigations Report 99-4081, 90 p.

Mullaney, J.R., Schwarz, G.E., and Trench, E.C.T., 2002, Estimation of nitrogen yields and loads from basins draining to Long Island Sound, 1988-98: U.S. Geological Survey Water-Resources Investigations Report 024044, 84 p.
Prudic, D.E., 1989, Documentation of a computer program to simulate stream-aquifer relations using a modular, finite-difference, ground-water flow model: U.S. Geological Survey Open-File Report 88-729, 113 p.

Rantz, S.E., 1982a, Measurement and computation of streamflow_-Volume 1. Measurement of stage and discharge: U.S. Geological Survey Water-Supply Paper 2175, p. 1-284. (Online at http://water.usgs.gov/pubs/wsp/wsp2175/)

Rantz, S.E., 1982b, Measurement and computation of streamflow-Volume 2. Computation of discharge: U.S. Geological Survey Water-Supply Paper 2175, p. 285-631. (Online at http://water.usgs.gov/pubs/wsp/wsp2175/)

Rodgers, John (compiler), 1985, Bedrock geological map of Connecticut: Connecticut Geological and Natural History Survey, Natural Resources Atlas Series Map, 2 sheets, scale 1:125,000.

Rutledge, A.T., 1998, Computer programs for describing the recession of ground-water discharge and for estimating mean ground-water recharge and discharge from streamflow records-Update: U.S. Geological Survey Water-Resources Investigations Report 98-4148, 43 p.

Ryder, R.B., Cervione, M.A., Jr., Thomas, C.E., Jr., and Thomas, M.P., 1970, Water resources inventory of Connecticut, part 4, southwestern coastal river basins: Connecticut Water Resources Bulletin 17, 54 p.

Solley, W.B., Pierce, R.R., Perlman, H.A., 1998, Estimated water use in the United States, 1995: U.S. Geological Survey Circular 1200, 71 p.

Stone, J.R., Schafer, J.P., London, E.H., and Thompson, W.B., 1992, Surficial materials map of Connecticut: U.S. Geological Special Map, scale 1:125,000, 2 sheets.

Thomas, M.P., 1966, Effect of glacial geology upon the time distribution of streamflow in eastern and southern Connecticut, in Geological Survey Research 1966: U.S. Geological Survey Professional Paper 550-B, p. B209B212.

Tiedeman, C.R., Goode, D.J., and Hsieh, P.A., 1997, Numerical simulation of ground-water flow through glacial deposits and crystalline bedrock in the Mirror Lake area, Grafton County, New Hampshire: U.S. Geological Survey Professional Paper 157250 p.

U.S. Department of Commerce, 1991, 1990 census of population and housing, summary population and housing characteristics, Connecticut: Washington D.C., Bureau of the Census, publication 1990/CPH-1-8. 64 p.

U.S. Environmental Protection Agency, 2000, Ambient water quality criteria recommendations-Information supporting the development of State and Tribal nutrient criteria; rivers and streams in nutrient ecoregion XIV: U.S. Environmental Protection Agency, Office of Water EPA 822-B00-022, 84 p. 
2001, Ambient water quality criteria recommendations-Information supporting the development of State and Tribal nutrient criteria; lakes and reservoirs in nutrient ecoregion XIV: U.S. Environmental Protection Agency, Office of Water EPA 822-B01-011, 123 p.

U.S. Geological Survey, 1995, National handbook of recommended methods for water-data acquisition. Chap. 11-Water use: U.S. Geological Survey Office of Water Data Coordination, Available online at http://water.usgs.gov/pubs/chapter11/ accessed February 20, 2003.

Weiss, L.A., 1983, Evaluation and design of a streamflowdata network for Connecticut: Connecticut Water Resources Bulletin no. 36, 31 p.

Wilde, F.D., and Radtke, 1998, National field manual for the collection of water quality data--Field measurements: U.S. Geological Survey Techniques of WaterResources Investigations, book 9, chap. A6, variously paginated.

Wilde, F.D., Radtke, D.B., Gibs, Jacob, and Iwatsubo, R.T., 1998a, National field manual for the collection of water quality data--Preparation for water sampling: U.S. Geological Survey Techniques of Water-Resources Investigations, book 9, chap. A1, 47 p.
Wilde, F.D., Radtke, D.B., Gibs, Jacob, and Iwatsubo, R.T., 1998b, National field manual for the collection of water quality data--Selection of equipment for water sampling: U.S. Geological Survey Techniques of Water-Resources Investigations, book 9, chap. A2, 94 p.

Wilde, F.D., Radtke, D.B., Gibs, Jacob, and Iwatsubo, R.T., 1998c, National field manual for the collection of water quality data--Cleaning of equipment for water sampling: U.S. Geological Survey Techniques of Water-Resources Investigations, book 9, chap. A3, 75 p.

Wilde, F.D., Radtke, D.B., Gibs, Jacob, and Iwatsubo, R.T., 1999a, National field manual for the collection of water quality data--Collection of water samples: U.S. Geological Survey Techniques of Water-Resources Investigations, book 9, chap. A4, 156 p.

Wilde, F.D., Radtke, D.B., Gibs, Jacob, and Iwatsubo, R.T., 1999b, National field manual for the collection of water quality data--Processing of water samples: U.S. Geological Survey Techniques of Water-Resources Investigations, book 9, chap. A5, 149 p.

Wolcott, S.W., and Snow, R.V., 1995, Computation of bedrock-aquifer recharge in northern Westchester County, New York, and chemical quality of water from selected bedrock wells: U.S. Geological Survey WaterResources Investigations Report 92-4157, 57 p. 


\begin{tabular}{l}
\hline Appendixes 1-4. \\
\hline \hline
\end{tabular}


Appendix 1. Records from two U.S. Geological Survey streamflow-gaging stations, Greenwich, Connecticut, March 2001-September 2002.

\section{Station 01211699 E. Br. Byram R. Below Lake Mead At Round Hill}

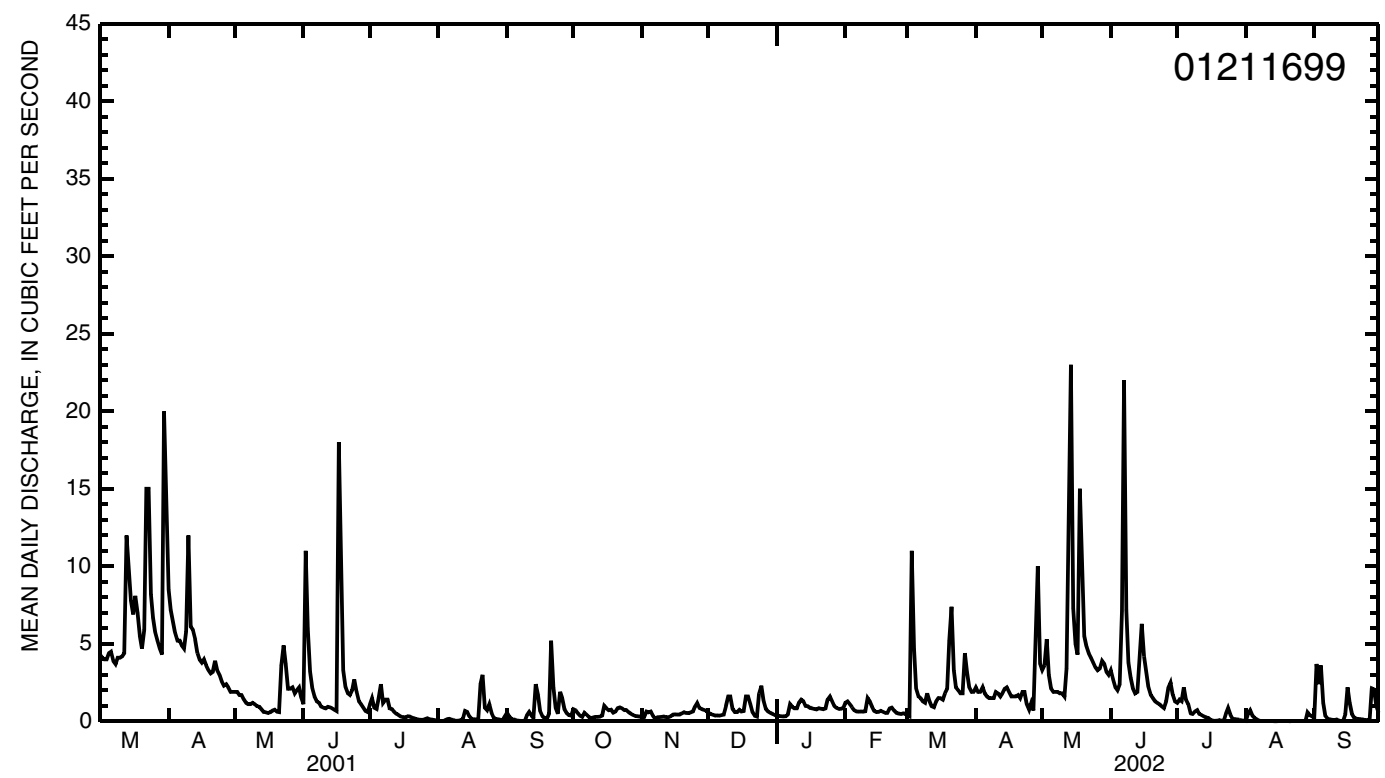

STATION NUMBER 01211699 E. BR. BYRAM R. BELOW LAKE MEAD AT ROUND HILL SOURCE AGENCY USGS STATE 09 COUNTY 001 LATITUDE 410558 LONGITUDE 0734101.5 NAD27 DRAINAGE AREA 1.65* CONTRIBUTING DRAINAGE AREA 1.65 DATUM 330 NGVD29 DISCHARGE, in CFS, WATER YEAR OCTOBER 2000 TO SEPTEMBER 2001. DATA COLLECTION BEGAN FEBRUARY 2001.

\section{DAILY MEAN VALUES}

\begin{tabular}{|c|c|c|c|c|c|c|c|c|c|c|c|c|}
\hline DAY & $\mathrm{OCT}$ & NOV & $\mathrm{DEC}$ & JAN & FEB & MAR & APR & MAY & JUN & JUL & AUG & SEP \\
\hline 1 & --- & - - - & --- & - - - & - - - & 4.3 & 8.5 & 1.9 & 1.1 & 1.1 & 0.03 & 0.57 \\
\hline 2 & --- & - - - & --- & --- & -- & 4.1 & 7.2 & 1.9 & 11 & 1.5 & 0.02 & 0.31 \\
\hline 3 & --- & --- & --- & -- & -- & 4.0 & 6.4 & 1.7 & 6.0 & 0.88 & 0.01 & 0.17 \\
\hline 4 & --- & --- & --- & --- & --- & 4.0 & 5.7 & 1.7 & 3.2 & 0.79 & 0.07 & 0.11 \\
\hline 5 & --- & --- & --- & - - - & - - - & 4.4 & 5.2 & 1.4 & 2.1 & 1.5 & 0.14 & 0.08 \\
\hline 6 & -- & --- & --- & - - - & - - - & 4.5 & 5.2 & 1.2 & 1.6 & 2.4 & 0.16 & 0.04 \\
\hline 7 & --- & --- & --- & -- & -- & 3.9 & 4.9 & 1.1 & 1.3 & 1.2 & 0.11 & 0.03 \\
\hline 8 & --- & --- & --- & - - & -- & 3.7 & 4.7 & 1.1 & 1.2 & 1.4 & 0.06 & 0.02 \\
\hline 9 & --- & --- & -- & -- & - - - & 4.1 & 5.8 & 1.2 & 0.95 & 1.4 & 0.03 & 0.02 \\
\hline 10 & --- & --- & --- & --- & --- & 4.1 & 12 & 1.1 & 0.88 & 0.84 & 0.04 & 0.40 \\
\hline 11 & -- & --- &.- & -- & - - - & 4.2 & 6.1 & 0.99 & 0.83 & 0.79 & 0.06 & 0.61 \\
\hline 12 & --- & --- & --- & --- & -- & 4.4 & 5.9 & 0.95 & 0.94 & 0.62 & 0.17 & 0.38 \\
\hline 13 & --- & --- & --- & --- & --- & 12 & 5.3 & 0.78 & 0.90 & 0.49 & 0.67 & 0.22 \\
\hline 14 & --- & --- & --- & -- & -- & 10 & 4.4 & 0.61 & 0.83 & 0.40 & 0.61 & 2.4 \\
\hline 15 & --- & --- & --- & -- & -- & 7.8 & 4.0 & 0.58 & 0.74 & 0.31 & 0.32 & 1.7 \\
\hline 16 & -- & --- & -- & - - - & -- & 6.9 & 3.8 & 0.54 & 0.66 & 0.27 & 0.17 & 0.67 \\
\hline 17 & -- & --- & --- & -- & -- & 8.1 & 4.0 & 0.59 & 18 & 0.24 & 0.12 & 0.34 \\
\hline 18 & --- & --- & --- & -- & -- & 7.0 & 3.6 & 0.70 & 8.4 & 0.33 & 0.12 & 0.21 \\
\hline 19 & --- & --- & -- & -- & -- & 5.5 & 3.3 & 0.75 & 3.3 & 0.31 & 0.08 & 0.15 \\
\hline 20 & --- & --- & --- & --- & -- & 4.7 & 3.1 & 0.62 & 2.2 & 0.25 & 2.4 & 0.52 \\
\hline 21 & -- & --- &.-- & -- & - - - & 5.9 & 3.2 & 0.59 & 1.8 & 0.20 & 3.0 & 5.2 \\
\hline 22 & --- & --- & --- & --- & -- & 15 & 3.9 & 3.6 & 1.7 & 0.14 & 0.86 & 2.2 \\
\hline 23 & --- & --- & --- & -- & -- & 15 & 3.3 & 4.9 & 2.0 & 0.11 & 0.71 & 0.84 \\
\hline 24 & --- & --- & -- & -- & 3.3 & 8.2 & 3.0 & 3.7 & 2.7 & 0.10 & 1.1 & 0.49 \\
\hline 25 & --- & --- & --- & --- & 4.9 & 6.7 & 2.6 & 2.1 & 1.9 & 0.10 & 0.54 & 1.9 \\
\hline 26 & --- & --- & --- & -- & 8.2 & 5.7 & 2.3 & 2.1 & 1.3 & 0.15 & 0.25 & 1.5 \\
\hline 27 & --- & --- & -- & -- & 6.1 & 5.2 & 2.4 & 2.2 & 1.1 & 0.21 & 0.15 & 0.78 \\
\hline 28 & --- & --- & --- & -- & 5.0 & 4.7 & 2.2 & 1.8 & 0.88 & 0.13 & 0.13 & 0.53 \\
\hline 29 & --- & --- & --- & - - - & -- & 4.3 & 1.9 & 2.0 & 0.67 & 0.11 & 0.10 & 0.41 \\
\hline 30 & -- & --- & -- & - - - &.- & 20 & 1.9 & 2.2 & 0.60 & 0.09 & 0.06 & 0.36 \\
\hline 31 & --- & --- & --- & - - - & -- & 14 & - - - & 1.5 & - - - & 0.06 & 0.32 & --- \\
\hline
\end{tabular}


Appendix 1. Records from two U.S. Geological Survey streamflow-gaging stations, Greenwich, Connecticut, March 2001-September 2002.-Continued

\section{Station 01211699 E. Br. Byram R. Below Lake Mead At Round Hill-Continued}

STATION NUMBER 01211699 E. BR. BYRAM R. BELOW LAKE MEAD AT ROUND HILL SOURCE AGENCY USGS STATE 09 COUNTY 001 LATITUDE 410558 LONGITUDE 0734101.5 NAD27 DRAINAGE AREA $1.65^{*}$ CONTRIBUTING DRAINAGE AREA 1.65 DATUM 330 NGVD29 DISCHARGE, in CFS, WATER YEAR OCTOBER 2001 TO SEPTEMBER 2002

DAILY MEAN VALUES

\begin{tabular}{|c|c|c|c|c|c|c|c|c|c|c|c|c|}
\hline DAY & $\mathrm{OCT}$ & NOV & $\mathrm{DEC}$ & JAN & $\mathrm{FEB}$ & MAR & $\mathrm{APR}$ & MAY & JUN & JUL & AUG & SEP \\
\hline 1 & 0.78 & 0.33 & 0.55 & 0.36 & 1.2 & 0.39 & 2.2 & 3.3 & 3.3 & 1.2 & 0.02 & 0.20 \\
\hline 2 & 0.72 & 0.29 & 0.47 & 0.34 & 1.3 & 0.33 & 1.9 & 3.6 & 2.7 & 1.4 & 0.50 & 3.7 \\
\hline 3 & 0.52 & 0.64 & 0.43 & 0.32 & 1.1 & 11 & 1.9 & 5.3 & 2.2 & 1.3 & 0.71 & 2.4 \\
\hline 4 & 0.36 & 0.58 & 0.37 & 0.31 & 0.90 & 4.7 & 2.2 & 3.0 & 2.0 & 2.2 & 0.37 & 3.6 \\
\hline 5 & 0.29 & 0.63 & 0.38 & 0.33 & 0.72 & 2.1 & 1.8 & 2.1 & 2.4 & 1.4 & 0.22 & 1.2 \\
\hline 6 & 0.55 & 0.35 & 0.36 & 0.44 & 0.64 & 1.6 & 1.6 & 1.9 & 7.1 & 1.1 & 0.14 & 0.37 \\
\hline 7 & 0.44 & 0.18 & 0.40 & 1.1 & 0.62 & 1.5 & 1.5 & 1.9 & 22 & 0.52 & 0.05 & 0.18 \\
\hline 8 & 0.27 & 0.26 & 0.44 & 0.93 & 0.64 & 1.3 & 1.5 & 1.9 & 7.2 & 0.48 & 0.02 & 0.12 \\
\hline 9 & 0.22 & 0.27 & 0.98 & 0.83 & 0.62 & 1.2 & 1.5 & 1.8 & 3.8 & 0.64 & 0.01 & 0.10 \\
\hline 10 & 0.26 & 0.29 & 1.6 & 0.84 & 0.65 & 1.8 & 1.9 & 1.8 & 2.8 & 0.73 & 0.01 & 0.08 \\
\hline 11 & 0.28 & 0.31 & 1.6 & 1.2 & 1.5 & 1.3 & 1.8 & 1.6 & 2.1 & 0.48 & 0.01 & 0.12 \\
\hline 12 & 0.29 & 0.27 & 0.79 & 1.4 & 1.3 & 0.97 & 1.6 & 3.4 & 1.8 & 0.41 & 0.01 & 0.05 \\
\hline 13 & 0.30 & 0.26 & 0.59 & 1.3 & 0.94 & 0.91 & 1.8 & 14 & 1.9 & 0.32 & 0.01 & 0.02 \\
\hline 14 & 0.36 & 0.33 & 0.59 & 1.0 & 0.67 & 1.3 & 2.1 & 23 & 3.8 & 0.25 & 0.0 & 0.02 \\
\hline 15 & 1.0 & 0.43 & 0.74 & 0.97 & 0.60 & 1.5 & 2.2 & 7.3 & 6.3 & 0.22 & 0.0 & 0.46 \\
\hline 16 & 0.83 & 0.45 & 0.63 & 0.87 & 0.61 & 1.5 & 1.9 & 5.0 & 4.2 & 0.11 & 0.02 & 2.2 \\
\hline 17 & 0.71 & 0.44 & 0.66 & 0.84 & 0.67 & 1.4 & 1.6 & 4.3 & 3.2 & 0.05 & 0.01 & 1.2 \\
\hline 18 & 0.75 & 0.44 & 1.6 & 0.79 & 0.61 & 1.8 & 1.6 & 15 & 2.2 & 0.03 & 0.01 & 0.48 \\
\hline 19 & 0.55 & 0.51 & 1.6 & 0.77 & 0.54 & 2.1 & 1.6 & 9.5 & 1.7 & 0.04 & 0.01 & 0.25 \\
\hline 20 & 0.62 & 0.60 & 1.1 & 0.85 & 0.54 & 5.2 & 1.7 & 5.5 & 1.5 & 0.08 & 0.01 & 0.17 \\
\hline 21 & 0.85 & 0.54 & 0.60 & 0.81 & 0.83 & 7.4 & 1.5 & 4.8 & 1.3 & 0.05 & 0.0 & 0.15 \\
\hline 22 & 0.91 & 0.53 & 0.36 & 0.78 & 0.89 & 3.3 & 1.9 & 4.4 & 1.2 & 0.03 & 0.01 & 0.13 \\
\hline 23 & 0.84 & 0.58 & 0.31 & 0.84 & 0.70 & 2.2 & 1.9 & 4.1 & 1.1 & 0.52 & 0.01 & 0.12 \\
\hline 24 & 0.71 & 0.64 & 1.8 & 1.4 & 0.56 & 2.0 & 1.1 & 3.8 & 0.96 & 0.86 & 0.01 & 0.08 \\
\hline 25 & 0.73 & 0.96 & 2.3 & 1.6 & 0.50 & 1.8 & 0.75 & 3.5 & 0.85 & 0.43 & 0.01 & 0.06 \\
\hline 26 & 0.59 & 1.2 & 1.3 & 1.3 & 0.48 & 1.8 & 1.2 & 3.3 & 1.3 & 0.18 & 0.01 & 0.14 \\
\hline 27 & 0.49 & 0.86 & 0.81 & 1.0 & 0.52 & 4.4 & 0.70 & 3.4 & 2.2 & 0.14 & 0.01 & 2.1 \\
\hline 28 & 0.41 & 0.80 & 0.64 & 0.87 & 0.50 & 3.2 & 4.1 & 3.9 & 2.5 & 0.13 & 0.01 & 2.1 \\
\hline 29 & 0.34 & 0.74 & 0.56 & 0.80 & --- & 2.2 & 10 & 3.7 & 1.7 & 0.11 & 0.58 & 0.97 \\
\hline 30 & 0.33 & 0.67 & 0.48 & 0.81 & --- & 1.9 & 3.7 & 3.2 & 1.3 & 0.06 & 0.39 & 0.55 \\
\hline 31 & 0.30 & --- & 0.41 & 0.87 & --- & 1.9 & --- & 3.0 & --- & 0.04 & 0.31 & --- \\
\hline
\end{tabular}


Appendix 1. Records from two U.S. Geological Survey streamflow-gaging stations, Greenwich, Connecticut, March 2001-September 2002.-Continued

\section{Station 01211110 Unnamed Tributary To Greenwich Creek Nr Cos Cob}

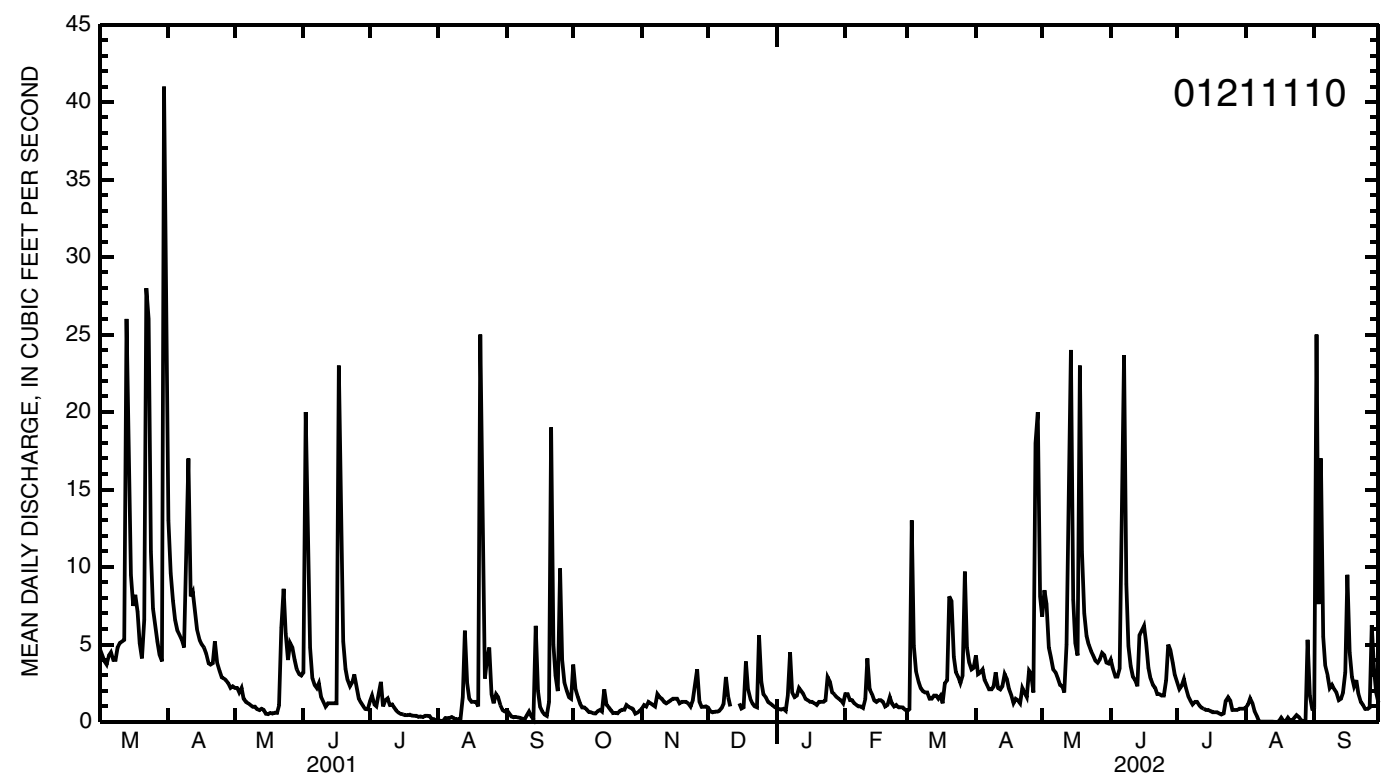

STATION NUMBER 01211110 UNNAMED TRIBUTARY TO GREENWICH CREEK NR COS COB STREAM SOURCE AGENCY USGS STATE 09 COUNTY 001 LATITUDE 410233.5 LONGITUDE 0733659.3 NAD27 DRAINAGE AREA 2.19* CONTRIBUTING DRAINAGE AREA 2.19 DATUM 65 NGVD29 DISCHARGE, in CFS, WATER YEAR OCTOBER 2000 TO SEPTEMBER 2001. DATA COLLECTION BEGAN MARCH 2001.

DAILY MEAN VALUES

\begin{tabular}{|c|c|c|c|c|c|c|c|c|c|c|c|c|}
\hline DAY & OCT & NOV & $\mathrm{DEC}$ & JAN & FEB & MAR & APR & MAY & JUN & JUL & AUG & SEP \\
\hline 1 & --- & --- & --- & --- & --- & 4.7 & 13 & 2.2 & 3.2 & e1. 3 & 0.10 & 0.75 \\
\hline 2 & --- & --- & --- & --- & --- & 4.3 & 9.6 & 2.2 & 20 & e1.7 & 0.07 & 0.56 \\
\hline 3 & --- & --- & --- & --- & --- & 3.9 & 7.8 & 1.9 & 12 & e1.1 & 0.04 & 0.36 \\
\hline 4 & --- & --- & --- & --- & --- & 3.7 & 6.6 & 2.2 & 4.8 & e1.0 & e0.25 & 0.30 \\
\hline 5 & --- & --- & --- & --- & --- & 4.3 & 5.9 & 1.5 & 2.8 & e1.8 & e 0.25 & 0.33 \\
\hline 6 & --- & --- & -- & --- & --- & 4.5 & 5.6 & 1.3 & 2.4 & e2. 6 & e 0.25 & 0.29 \\
\hline 7 & --- & --- & --- & --- & --- & 4.0 & 5.3 & 1.2 & 2.2 & 1.0 & 0.31 & 0.26 \\
\hline 8 & --- & --- & --- & --- & --- & 4.0 & 4.8 & 1.1 & 2.5 & $\mathrm{e} 1.4$ & e 0.23 & 0.21 \\
\hline 9 & --- & --- & --- & --- & --- & 4.8 & 10 & 0.97 & 1.6 & e1. 5 & 0.18 & 0.18 \\
\hline 10 & --- & --- & --- & --- & --- & 5.1 & 17 & 0.99 & 1.3 & e1.1 & e 0.17 & 0.42 \\
\hline 11 & --- & --- & --- & --- & --- & 5.2 & 8.1 & 0.82 & 1.0 & e1.1 & e0.19 & 0.68 \\
\hline 12 & --- & --- & --- & --- & --- & 5.3 & 8.4 & 0.76 & 1.2 & e0.94 & 1.6 & 0.36 \\
\hline 13 & --- & --- & --- & --- & --- & 26 & 7.0 & 0.85 & 1.2 & e0.73 & 5.9 & 0.17 \\
\hline 14 & --- & --- & --- & --- & --- & 15 & 5.9 & 0.79 & 1.2 & $\mathrm{e} 0.60$ & 2.5 & 6.2 \\
\hline 15 & --- & --- & --- & --- & --- & 9.5 & 5.3 & 0.53 & 1.2 & e 0.52 & 1.5 & 2.0 \\
\hline 16 & --- & --- & --- & --- & --- & 7.5 & 5.0 & 0.50 & 1.2 & e0.49 & 1.3 & 0.98 \\
\hline 17 & --- & --- & --- & --- & --- & 8.2 & 4.8 & 0.59 & 23 & e 0.44 & 1.3 & 0.66 \\
\hline 18 & --- & --- & --- & --- & --- & 7.1 & 4.4 & 0.55 & 10 & e 0.44 & 1.3 & 0.49 \\
\hline 19 & --- & --- & --- & --- & --- & 5.1 & 3.8 & 0.60 & 5.2 & e 0.47 & 1.0 & 0.39 \\
\hline 20 & --- & --- & --- & --- & --- & 4.1 & 3.7 & 0.58 & $\mathrm{e} 3.4$ & e 0.41 & 25 & 1.3 \\
\hline 21 & --- & --- & --- & --- & --- & 6.6 & 3.8 & 1.1 & e2. 7 & e0.39 & 12 & 19 \\
\hline 22 & --- & --- & --- & --- & --- & 28 & 5.2 & 6.1 & $\mathrm{e} 2.3$ & e0.39 & 2.8 & 5.0 \\
\hline 23 & --- & --- & --- & --- & --- & 26 & 3.8 & 8.6 & e2. 6 & e0.33 & 4.0 & 3.0 \\
\hline 24 & --- & --- & --- & --- & --- & 11 & 3.3 & 5.7 & e3.1 & e0.36 & 4.8 & 2.0 \\
\hline 25 & --- & --- & --- & --- & --- & 7.3 & 2.9 & 4.0 & $\mathrm{e} 2.2$ & e0.31 & 1.8 & 9.9 \\
\hline 26 & --- & --- & --- & --- & --- & 6.2 & 2.8 & 5.1 & 1.5 & e 0.39 & 1.2 & 4.0 \\
\hline 27 & --- & --- & --- & --- & --- & 5.2 & 2.7 & 4.8 & e1.2 & e0.39 & 1.8 & 2.5 \\
\hline 28 & --- & --- & --- & --- & --- & 4.3 & 2.5 & 4.0 & e1.0 & 0.38 & 1.6 & 2.0 \\
\hline 29 & --- & --- & $-\ldots$ & --- &.-- & 3.9 & 2.2 & 3.4 & e 0.84 & 0.18 & 1.1 & 1.6 \\
\hline 30 & --- & --- & --- & --- & --- & 41 & 2.3 & 3.1 & e 0.81 & 0.18 & 0.77 & 1.5 \\
\hline 31 & --- & --- & --- & --- & --- & 24 & --- & 3.0 & --- & 0.10 & 0.68 & - - - \\
\hline
\end{tabular}

e Estimated 
Appendix 1. Records from two U.S. Geological Survey streamflow-gaging stations, Greenwich, Connecticut, March 2001-September 2002.-Continued

Station 01211110 Unnamed Tributary To Greenwich Creek Nr Cos Cob-Continued

STATION NUMBER 01211110 UNNAMED TRIBUTARY TO GREENWICH CREEK NR COS COB STREAM SOURCE AGENCY USGS STATE 09 COUNTY O01
LATITUDE 410233.5 LONGITUDE 0733659.3 NAD27 DRAINAGE AREA $2.19 *$ CONTRIBUTING DRAINAGE AREA 2.19 DISCHARGE, in CFS, WATER YEAR OCTOBER 2001 TO SEPTEMBER 2002

DAILY MEAN VALUES

\begin{tabular}{|c|c|c|c|c|c|c|c|c|c|c|c|c|}
\hline DAY & OCT & NOV & $\mathrm{DEC}$ & JAN & FEB & MAR & APR & MAY & JUN & JUL & AUG & SEP \\
\hline 1 & 3.7 & 0.88 & 0.92 & 0.88 & 1.8 & 0.70 & 4.3 & 6.8 & e4.0 & e2. 6 & $\mathrm{e} 0.92$ & 0.93 \\
\hline 2 & 2.1 & 1.1 & 0.68 & 0.82 & 1.8 & 0.82 & 3.1 & 8.5 & e3. 4 & e2. 1 & e1.1 & 25 \\
\hline 3 & 1.6 & 1.0 & 0.62 & 0.80 & 1.4 & 13 & 3.2 & 7.6 & e2. 9 & e2. 3 & e1. 5 & 7.6 \\
\hline 4 & 1.2 & 1.3 & 0.66 & 0.85 & 1.4 & 4.9 & 3.4 & 4.8 & e2. 9 & e2. 8 & $\mathrm{e} 1.2$ & 17 \\
\hline 5 & 0.94 & 1.2 & 0.67 & 0.72 & 1.2 & 3.2 & 2.7 & 4.1 & e3. 5 & e2. 2 & e0.70 & 5.5 \\
\hline 6 & 0.93 & 1.1 & 0.72 & 1.7 & 1.1 & 2.6 & 2.4 & 3.4 & e9. 4 & e1.7 & e0.40 & 3.6 \\
\hline 7 & 0.81 & 1.0 & 0.89 & 4.5 & 1.0 & 2.2 & 2.1 & 3.2 & e24 & e1. 4 & 0.02 & 3.0 \\
\hline 8 & 0.64 & 1.8 & 1.2 & 1.9 & 1.0 & 2.0 & 2.1 & 2.8 & 8.9 & e1.1 & 0.02 & 2.2 \\
\hline 9 & 0.63 & 1.6 & 2.9 & 1.6 & 0.91 & 1.9 & 2.3 & 2.4 & 4.9 & e1.3 & 0.02 & 2.4 \\
\hline 10 & 0.56 & 1.5 & 1.6 & 1.7 & 1.5 & 1.9 & 3.2 & 2.3 & 3.6 & e1. 3 & 0.02 & 2.1 \\
\hline 11 & 0.55 & 1.3 & 1.0 & 2.2 & 4.1 & 1.5 & 2.2 & 1.9 & 2.9 & e1.1 & 0.02 & 1.9 \\
\hline 12 & 0.69 & 1.2 & -- & 2.0 & 2.1 & 1.5 & 2.1 & 5.0 & 2.7 & e0.92 & 0.02 & 1.4 \\
\hline 13 & 0.77 & 1.3 & --- & 1.8 & 1.8 & 1.7 & 2.3 & 17 & 2.3 & e0.85 & 0.02 & 1.5 \\
\hline 14 & 0.67 & 1.4 & --- & 1.5 & 1.4 & 1.7 & 3.1 & 24 & 5.6 & e 0.77 & 0.01 & 1.9 \\
\hline 15 & 2.1 & 1.5 & 1.2 & 1.4 & 1.3 & 1.5 & 2.8 & 7.9 & 5.9 & e 0.77 & 0.01 & 3.2 \\
\hline 16 & 1.1 & 1.5 & 0.87 & 1.3 & 1.4 & 1.7 & 2.1 & 5.1 & 6.2 & e0.70 & 0.05 & 9.5 \\
\hline 17 & 0.95 & 1.5 & 0.95 & 1.3 & 1.4 & 1.2 & 1.7 & 4.3 & 5.1 & $\mathrm{e} 0.63$ & 0.27 & 4.5 \\
\hline 18 & 0.75 & 1.2 & 3.9 & 1.2 & 1.3 & 2.5 & 1.2 & 23 & 3.5 & e0.63 & 0.06 & 2.9 \\
\hline 19 & 0.57 & 1.3 & 2.1 & 1.1 & 1.0 & 2.7 & 1.5 & 11 & 2.8 & $\mathrm{e} 0.63$ & 0.04 & 2.3 \\
\hline 20 & 0.59 & 1.3 & 1.5 & 1.3 & 1.1 & 8.1 & 1.4 & e7.0 & 2.4 & e0. 55 & 0.27 & 2.7 \\
\hline 21 & 0.56 & 1.3 & 1.2 & 1.3 & 1.6 & 7.8 & 1.2 & e5. 6 & 2.2 & e0.48 & 0.08 & 1.8 \\
\hline 22 & 0.71 & 1.2 & 1.0 & 1.3 & 1.2 & 4.2 & 2.2 & e5.0 & 1.8 & e 0.55 & 0.10 & 1.3 \\
\hline 23 & 0.78 & 1.0 & 0.94 & 1.4 & 1.0 & 3.2 & 1.9 & e4. 6 & 1.8 & e1.4 & 0.27 & 1.1 \\
\hline 24 & 0.78 & 1.4 & 5.6 & 2.9 & 1.1 & 2.9 & 1.6 & e4. 3 & 1.7 & e1. 6 & 0.43 & 0.84 \\
\hline 25 & 1.1 & 2.3 & 2.6 & 2.6 & 0.94 & 2.5 & 3.3 & e4.0 & 1.7 & e1. 4 & 0.31 & 0.84 \\
\hline 26 & 0.98 & 3.4 & 1.8 & 1.9 & 0.95 & 3.0 & 3.1 & e3. 8 & 2.7 & e0.77 & 0.11 & 0.95 \\
\hline 27 & 0.91 & 1.3 & 1.6 & 1.8 & 0.93 & 9.7 & 1.9 & e 4.0 & 5.0 & e 0.77 & 0.04 & 6.2 \\
\hline 28 & 0.82 & 0.98 & 1.3 & 1.6 & 0.78 & 4.8 & 18 & e 4.4 & 4.6 & e 0.77 & 0.04 & 3.4 \\
\hline 29 & 0.53 & 0.97 & 1.2 & 1.5 & --- & 3.8 & 20 & e 4.3 & e3. 8 & e 0.85 & 5.3 & 1.9 \\
\hline 30 & 0.60 & 1.0 & 1.1 & 1.4 & --- & 3.4 & 8.1 & e3.8 & e3.0 & e 0.85 & 1.7 & 1.3 \\
\hline 31 & 0.72 & --- & 0.96 & 1.2 & --- & 3.5 & --- & e3. 8 & --- & e0.85 & 0.87 & --- \\
\hline
\end{tabular}

Estimated 
Appendix 2. Estimated average daily ground-water use for the Greenwich area, Connecticut. [gal/d, gallon per day]

\begin{tabular}{|c|c|c|c|c|c|}
\hline Zone & $\begin{array}{c}\text { Average daily water } \\
\text { use Greenwich and } \\
\text { Stamford Conn. } \\
\text { (gal/d) }\end{array}$ & $\begin{array}{l}\text { Lower boundary } \\
\text { of the } 90 \text {-percent } \\
\text { confidence } \\
\text { interval } \\
\text { (gal/d) }\end{array}$ & $\begin{array}{l}\text { Upper boundary } \\
\text { of the } 90 \text {-percent } \\
\text { confidence } \\
\text { interval } \\
\text { (gal/d) }\end{array}$ & $\begin{array}{c}\text { Average daily } \\
\text { water use in } \\
\text { Westchester } \\
\text { County, N.Y. } \\
\text { (gal/d) }\end{array}$ & $\begin{array}{l}\text { Estimated tota } \\
\text { (gal/d) }\end{array}$ \\
\hline 1 & 41,000 & 33,000 & 50,000 & 6,500 & 47,000 \\
\hline 2 & 67,000 & 50,000 & 88,000 & 0 & 67,000 \\
\hline 3 & 51,000 & 37,000 & 67,000 & 0 & 51,000 \\
\hline 4 & 110,000 & 95,000 & 130,000 & 0 & 110,000 \\
\hline 5 & 5,000 & 2,800 & 8,000 & 0 & 5,000 \\
\hline 6 & 40,000 & 30,000 & 52,000 & 49,000 & 88,000 \\
\hline 7 & 78,000 & 58,000 & 100,000 & 0 & 78,000 \\
\hline 8 & 110,000 & 93,000 & 140,000 & 0 & 110,000 \\
\hline 9 & 19,000 & 12,000 & 26,000 & 9,500 & 28,000 \\
\hline 10 & 140,000 & 110,000 & 170,000 & 0 & 140,000 \\
\hline 11 & 35,000 & 26,000 & 45,000 & 0 & 35,000 \\
\hline 12 & 120,000 & 97,000 & 150,000 & 14,000 & 140,000 \\
\hline 13 & 99,000 & 78,000 & 120,000 & 17,000 & 120,000 \\
\hline 14 & 76,000 & 63,000 & 91,000 & 0 & 76,000 \\
\hline 15 & 9,900 & 6,000 & 15,000 & 0 & 9,900 \\
\hline 16 & 100,000 & 86,000 & 130,000 & 0 & 100,000 \\
\hline 17 & 37,000 & 27,000 & 49,000 & 0 & 37,000 \\
\hline 18 & 1,700 & 600 & 3,600 & 0 & 1,700 \\
\hline 19 & 240,000 & 210,000 & 280,000 & 0 & 240,000 \\
\hline 20 & 96,000 & 84,000 & 110,000 & 0 & 96,000 \\
\hline 21 & 16,000 & 11,000 & 23,000 & 0 & 16,000 \\
\hline 22 & 64,000 & 53,000 & 77,000 & 0 & 64,000 \\
\hline 23 & 0 & 0 & 0 & 0 & 0 \\
\hline 24 & 41,000 & 32,000 & 51,000 & 19,000 & 60,000 \\
\hline 25 & 65,000 & 28,000 & 120,000 & 0 & 65,000 \\
\hline 26 & 67,000 & 56,000 & 79,000 & 0 & 67,000 \\
\hline 27 & 59,000 & 49,000 & 69,000 & 0 & 59,000 \\
\hline 28 & 120,000 & 100,000 & 130,000 & 0 & 120,000 \\
\hline 29 & 25,000 & 19,000 & 32,000 & 0 & 25,000 \\
\hline 30 & 48,000 & 41,000 & 56,000 & 0 & 48,000 \\
\hline 31 & 23,000 & 18,000 & 30,000 & 0 & 23,000 \\
\hline 32 & 2,900 & 1,000 & 6,100 & 0 & 2,900 \\
\hline
\end{tabular}


Appendix 3. Estimated average daily summer ground-water use for the Greenwich area, Connecticut.

[gal/d, gallon per day]

\begin{tabular}{|c|c|c|c|c|c|}
\hline Zone & $\begin{array}{c}\text { Average daily } \\
\text { summer water use } \\
\text { Greenwich and } \\
\text { Stamford Conn., in } \\
\text { gal/d }\end{array}$ & $\begin{array}{l}\text { Lower boundary } \\
\text { of the } 90 \text {-percent } \\
\text { confidence } \\
\text { interval } \\
(\mathrm{gal} / \mathrm{d})\end{array}$ & $\begin{array}{l}\text { Upper boundary } \\
\text { of the } 90 \text {-percent } \\
\text { confidence } \\
\text { interval } \\
\text { (gal/d) }\end{array}$ & $\begin{array}{c}\text { Average daily } \\
\text { summer water } \\
\text { use in Westches- } \\
\text { ter County, N.Y. } \\
\text { (gal/d) }\end{array}$ & $\begin{array}{l}\text { Estimated total } \\
(\text { gal/d) }\end{array}$ \\
\hline 1 & 53,000 & 41,000 & 67,000 & 7,700 & 61,000 \\
\hline 2 & 95,000 & 65,000 & 130,000 & 0 & 95,000 \\
\hline 3 & 71,000 & 48,000 & 100,000 & 0 & 71,000 \\
\hline 4 & 150,000 & 120,000 & 180,000 & 0 & 150,000 \\
\hline 5 & 6,400 & 3,300 & 11,000 & 0 & 6,400 \\
\hline 6 & 55,000 & 39,000 & 75,000 & 59,000 & 110,000 \\
\hline 7 & 110,000 & 78,000 & 160,000 & 0 & 110,000 \\
\hline 8 & 160,000 & 120,000 & 200,000 & 0 & 160,000 \\
\hline 9 & 25,000 & 16,000 & 38,000 & 11,000 & 36,000 \\
\hline 10 & 190,000 & 150,000 & 250,000 & 0 & 190,000 \\
\hline 11 & 46,000 & 33,000 & 63,000 & 0 & 46,000 \\
\hline 12 & 170,000 & 130,000 & 230,000 & 18,000 & 190,000 \\
\hline 13 & 140,000 & 110,000 & 190,000 & 22,000 & 170,000 \\
\hline 14 & 100,000 & 81,000 & 130,000 & 0 & 100,000 \\
\hline 15 & 13,000 & 7,400 & 21,000 & 0 & 13,000 \\
\hline 16 & 150,000 & 120,000 & 180,000 & 0 & 150,000 \\
\hline 17 & 51,000 & 35,000 & 70,000 & 0 & 51,000 \\
\hline 18 & 2,200 & 680 & 4,900 & 0 & 2,200 \\
\hline 19 & 330,000 & 270,000 & 410,000 & 0 & 330,000 \\
\hline 20 & 120,000 & 110,000 & 150,000 & 0 & 120,000 \\
\hline 21 & 21,000 & 13,000 & 32,000 & 0 & 21,000 \\
\hline 22 & 85,000 & 67,000 & 100,000 & 0 & 85,000 \\
\hline 23 & 0 & 0 & 0 & 0 & 0 \\
\hline 24 & 52,000 & 37,000 & 70,000 & 23,000 & 75,000 \\
\hline 25 & 110,000 & 35,000 & 240,000 & 0 & 110,000 \\
\hline 26 & 87,000 & 72,000 & 100,000 & 0 & 87,000 \\
\hline 27 & 75,000 & 61,000 & 91,000 & 0 & 75,000 \\
\hline 28 & 150,000 & 130,000 & 170,000 & 0 & 150,000 \\
\hline 29 & 32,000 & 24,000 & 41,000 & 0 & 32,000 \\
\hline 30 & 60,000 & 50,000 & 72,000 & 0 & 60,000 \\
\hline 31 & 30,000 & 22,000 & 39,000 & 0 & 30,000 \\
\hline 32 & 4,000 & 1,200 & 8,900 & 0 & 4,000 \\
\hline
\end{tabular}


Appendix 4. Estimated average daily winter ground-water use for the Greenwich area, Connecticut.

[gal/d, gallon per day]

\begin{tabular}{|c|c|c|c|c|c|}
\hline Zone & $\begin{array}{c}\text { Average daily } \\
\text { winter water use } \\
\text { Greenwich and } \\
\text { Stamford Conn. } \\
\text { (gal/d) }\end{array}$ & $\begin{array}{l}\text { Lower boundary } \\
\text { of the } 90 \text {-percent } \\
\text { confidence } \\
\text { interval } \\
\text { (gal/d) }\end{array}$ & $\begin{array}{l}\text { Upper boundary } \\
\text { of the } 90 \text {-percent } \\
\text { confidence } \\
\text { interval } \\
\text { (gal/d) }\end{array}$ & $\begin{array}{c}\text { Average winter } \\
\text { season water use } \\
\text { in Westchester } \\
\text { County, N.Y. } \\
\text { (gal/d) }\end{array}$ & $\begin{array}{l}\text { Estimated total } \\
\text { (gal/d) }\end{array}$ \\
\hline 1 & 31,000 & 25,000 & 37,000 & 4,900 & 36,000 \\
\hline 2 & 48,000 & 38,000 & 59,000 & 0 & 48,000 \\
\hline 3 & 35,000 & 27,000 & 44,000 & 0 & 35,000 \\
\hline 4 & 82,000 & 71,000 & 94,000 & 0 & 82,000 \\
\hline 5 & 4,200 & 2,500 & 6,400 & 0 & 4,200 \\
\hline 6 & 27,000 & 21,000 & 35,000 & 37,000 & 64,000 \\
\hline 7 & 51,000 & 41,000 & 63,000 & 0 & 51,000 \\
\hline 8 & 80,000 & 67,000 & 94,000 & 0 & 80,000 \\
\hline 9 & 13,000 & 9,400 & 18,000 & 7,300 & 20,000 \\
\hline 10 & 89,000 & 76,000 & 100,000 & 0 & 89,000 \\
\hline 11 & 24,000 & 19,000 & 30,000 & 0 & 24,000 \\
\hline 12 & 80,000 & 67,000 & 94,000 & 10,000 & 90,000 \\
\hline 13 & 67,000 & 54,000 & 81,000 & 13,000 & 80,000 \\
\hline 14 & 54,000 & 46,000 & 63,000 & 0 & 54,000 \\
\hline 15 & 6,900 & 4,500 & 10,000 & 0 & 6,900 \\
\hline 16 & 73,000 & 62,000 & 85,000 & 0 & 73,000 \\
\hline 17 & 26,000 & 20,000 & 33,000 & 0 & 26,000 \\
\hline 18 & 1,200 & 470 & 2,300 & 0 & 1,200 \\
\hline 19 & 170,000 & 150,000 & 190,000 & 0 & 170,000 \\
\hline 20 & 72,000 & 64,000 & 81,000 & 0 & 72,000 \\
\hline 21 & 11,000 & 7,800 & 15,000 & 0 & 11,000 \\
\hline 22 & 45,000 & 38,000 & 53,000 & 0 & 45,000 \\
\hline 23 & 0 & 0 & 0 & 0 & 0 \\
\hline 24 & 29,000 & 24,000 & 36,000 & 15,000 & 44,000 \\
\hline 25 & 40,000 & 22,000 & 65,000 & 0 & 40,000 \\
\hline 26 & 54,000 & 46,000 & 63,000 & 0 & 54,000 \\
\hline 27 & 44,000 & 38,000 & 51,000 & 0 & 44,000 \\
\hline 28 & 90,000 & 82,000 & 100,000 & 0 & 90,000 \\
\hline 29 & 19,000 & 15,000 & 23,000 & 0 & 19,000 \\
\hline 30 & 38,000 & 32,000 & 43,000 & 0 & 38,000 \\
\hline 31 & 17,000 & 14,000 & 21,000 & 0 & 17,000 \\
\hline 32 & 2,000 & 800 & 4,100 & 0 & 2,000 \\
\hline
\end{tabular}

